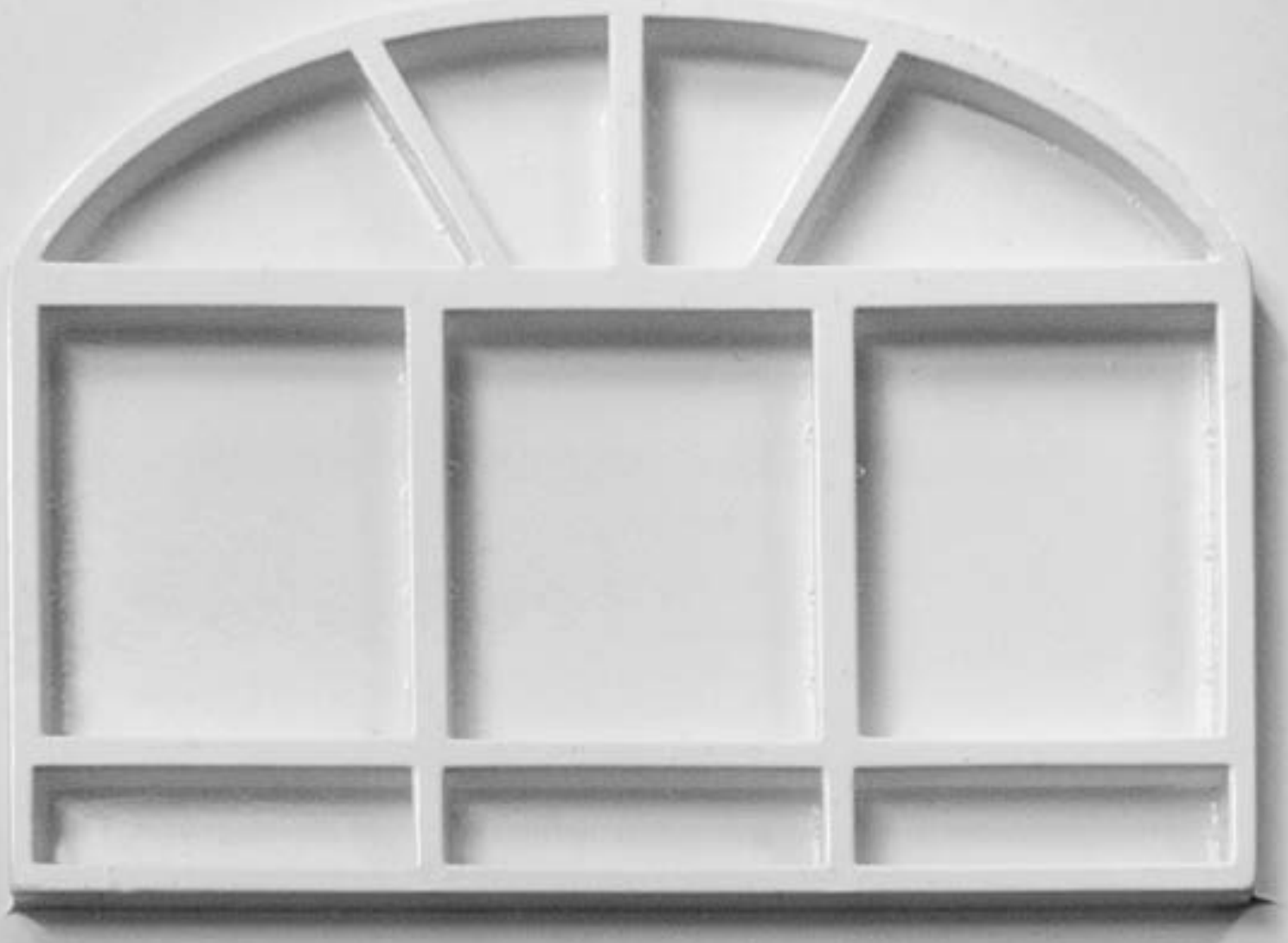





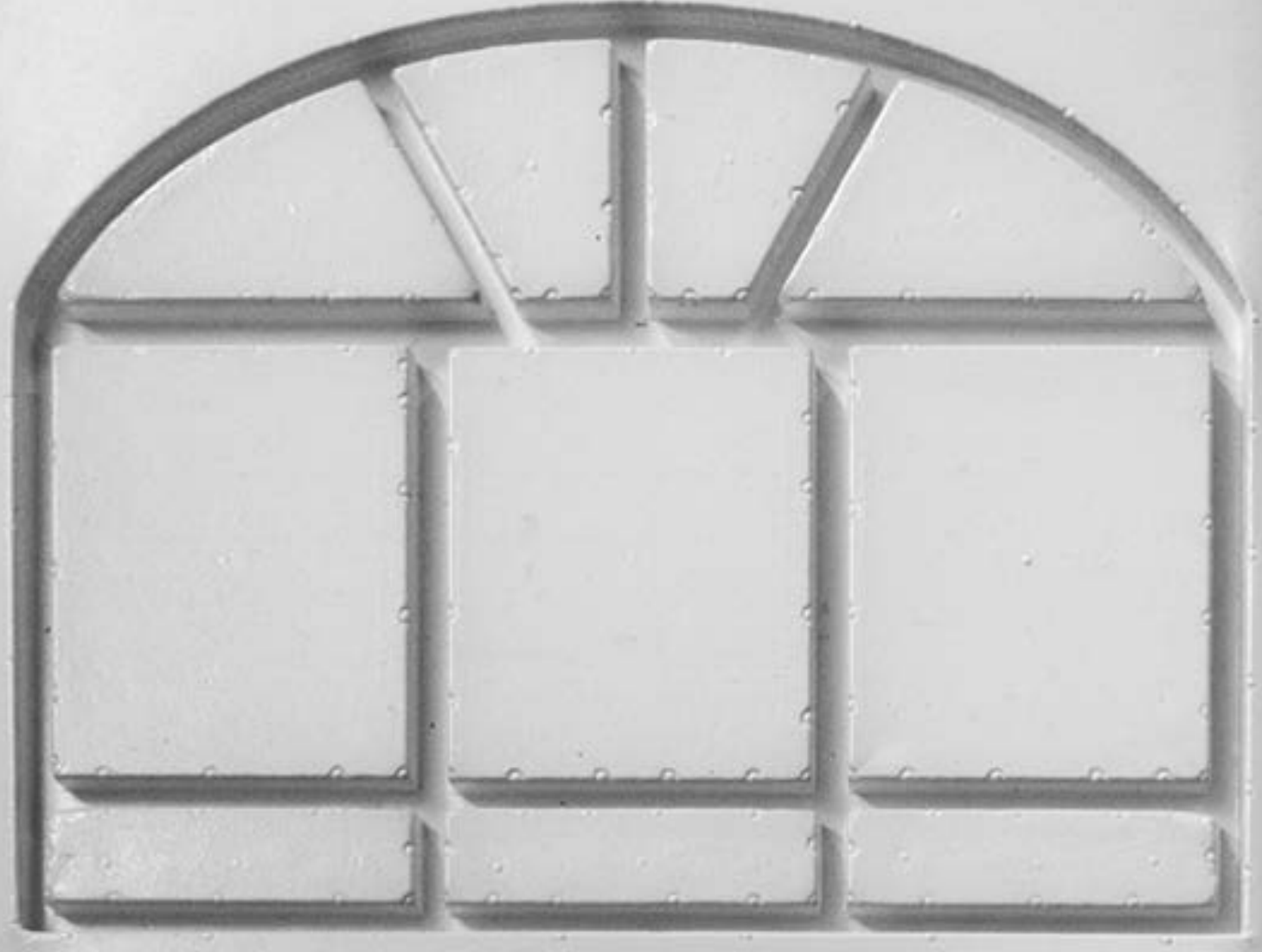


LUIZ RENATO MONTONE PERA

MOSTRUÁRIO SÃO PAULO

São Paulo

2016 

LUIZ RENATO MONTONE PERA

MOSTRUÁRIO SÃO PAULO

São Paulo

2016 


\section{MOSTRUÁRIO SÃO PAULO}

Dissertação apresentada ao Programa de Pós-Graduação em Artes Visuais, área de concentração Poéticas Visuais, da Escola de Comunicações e Artes da Universidade de São Paulo, como exigência parcial para a obtenção do título de Mestre em Artes Visuais, sob a orientação do Prof. Dr. Luiz Claudio Mubarac.

São Paulo

2016 
Defesa realizada em

l I 
LUIZ RENATO MONTONE PERA

\section{MOSTRUÁRIO SÃO PAULO}

Dissertação realizada com o auxílio de Bolsa de Mestrado da Fundação de Amparo à Pesquisa do Estado de São Paulo (FAPESP), processo n²014/18097-3. As opiniões, hipóteses e conclusões ou recomendações expressas neste material são de responsabilidade do autor e não necessariamente refletem a visão da FAPESP.

São Paulo

2016 
Agradeço ao meu orientador, o artista e professor Claudio Mubarac pelo acolhimento no Programa, e pelo apoio em toda a passagem. Agradeço também aos familiares, amigos e interlocutores que, com paciência, suportaram e participaram deste que foi o assunto a dominar, ao menos, os últimos três anos. À Fundação de Amparo à Pesquisa do Estado de São Paulo (FAPESP), pelo benefício da bolsa de estudos e pela avaliação rigorosa. Aos professores e funcionários da universidade com quem tive o prazer de dividir estas experiências. Agradeço ao amigo Mauro de Souza que enfrentou comigo o desafio do projeto gráfico desta dissertação. 


\section{RESUMO}

Os trabalhos artísticos e exposições empreendidos durante a pesquisa de Mestrado - 2014 a 2016 - foram motivados por investigações e vivências na cidade de São Paulo. Configurados a partir de reflexões sobre a paisagem urbana e sobre aspectos históricos e contemporâneos peculiares a essa cidade, à sua arquitetura, ao seu urbanismo e às suas narrativas. No entanto, algumas obras excedem o âmbito desta cidade. Pretende-se que seja comum a todas elas uma experiência poética centrada na produção de descontinuidades espaciais e temporais. O "tempo" - a duração temporal de uma experiência, a manipulação de sua intensidade, de sua continuidade ou de sua paralização - foi elemento estudado em todos os casos.

Palavras-chave: São Paulo, paisagem urbana, descontinuidade temporal, descontinuidade espacial. 


\section{ABSTRACT}

The artworks and exhibitions undertaken during Master research 2014 to 2016 - were motivated by investigation and experiences in the city of São Paulo. They took shape from reflections upon the urban landscape and on historical and contemporary aspects peculiar to this city, its architecture, its urbanism and its narratives. However, some works are beyond the scope of this city. It is intended to be common to all propositions a poetic experience centered on the production of spatial and temporal discontinuities. The "time" - the temporal duration of an experience, the elaboration of its intensity, its continuity or its paralysis - was studied in every case.

Keywords: São Paulo, urban landscape, temporal discontinuity, spatial discontinuity. 



\title{
INDICE
}

\author{
INTRODUÇÃO
}

PESQUISA ICONOGRÁFICA E HISTÓRICA SOBRE A CIDADE DE SÃO PAULO

A INVESTIGAÇÃO IN SITU E A VIVÊNCIA DA CIDADE

A INVESTIGAÇÃO SOBRE OS ELEMENTOS DA ARQUITETURA, A PARTIR DE SUA FENOMENOLOGIA

ESPAÇOS DE SILÊNCIO

ESCULTURA E CAMPO DA TRIDIMENSIONALIDADE (BREVE NOTA)

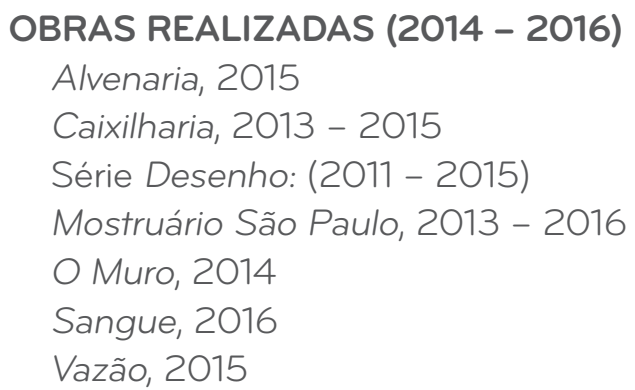

BIBLIOGRAFIA 


\section{INTRODUÇÃO}

Os trabalhos artísticos e as exposições empreendidos durante a pesquisa de Mestrado - 2014 a 2016 - foram motivados por investigações e vivências na cidade de São Paulo. Também são objetos de reflexão algumas obras realizadas anteriormente, desde, ao menos, 2007. Não deixam de ecoar intuições já manifestadas durante os primeiros anos de graduação, em 2004 e 2005.

O objetivo da pesquisa de Mestrado é dar vazão aos novos trabaIhos artísticos conjuntamente com uma reflexão crítica sobre os seus modos de aparição e produção, os repertórios que os alimentam, e que em seguida nutrem-se deles na geração de novas inquietações. 
Foram considerados como objetos da pesquisa:

1 Dispositivos arquitetônicos e elementos construtivos específicos, com historicidade, tradição funcional e estética atadas à história do desenvolvimento da cidade de São Paulo, como é o caso do tijolo de barro e da sua relação com a "cosmopolitização" da cidade, especialmente naquilo que tange aos processos imigratórios, ao ciclo econômico do café e ao acelerado crescimento urbano e demográfico, transformações profundas ocorridas entre meados do século XIX e primeiras décadas do século $X X_{i}$

2 Formas que se referem diretamente à paisagem urbana, como o desenho de fachadas e as amplas perspectivas oferecidas pelo sítio urbano da cidade de São Paulo;

3 Promoção de experiências de interdição, presentes nos trabaIhos artísticos elaborados a partir da vedação de janelas e da construção de muros (estruturas de vedação);

4 Referências literais à narrativas e memórias da cidade, como em "Caixilharia", série de imagens a partir da qual se propõe uma suposta evolução formal - ou a "sobrevivência" (Didi-Huberman) - de tipologias de janelas na cidade de São Paulo, do período colonial aos nossos dias.

5 Intervenções realizadas diretamente sobre a superfície da cidade, em contato com o contexto urbano, no espaço público. 
Quanto à experiência poética, considerou-se como eixo principal noções de descontinuidade espacial e temporal, e anacronismos. O "tempo" - a temporalidade da experiência, a manipulação de sua intensidade, de sua duração ou de sua paralização - foi elemento estudado em todos os casos. Importou também a investigação direta, in situ, de ruínas arquitetônicas e de objetos obsoletos que continuam em uso nas arquiteturas da cidade, de onde resultou o conceito espaços de silêncio, alusão a experiências temporais dilatadas ou suspensas promovidas por ambientes cuja particularidade é não exercerem uma função ativa em seus contextos, não participarem da experiência contemporânea do lugar. Ambientes e espaços inertes, encontrados (ruínas) ou artificialmente construídos. São comuns a este tipo de temporalidade que se busca definir aqui arquiteturas de autores como Luis Barragán (1902 - 1988), ligado ao modernismo arquitetônico mexicano, e Tadao Ando (1941), ligado à arquitetura contemporânea japonesa. Em seus projetos estes autores exploram espacialidades que promovem rupturas, descontinuidades na experiência cotidiana, que resultam em experiências de silêncio, suspensão temporal e desaceleração do movimento. Para abordar este conceito - espaços de silêncio - procurou-se refletir sobre as ruínas e sobre noções de sobreposição e simultaneidade temporal (anacronismos), cuja referência principal são noções formuladas pelo artista Robert Smithson (1938 - 1973) em textos e obras, além de uma breve reflexão sobre a prática dos dois arquitetos que tem servido de referência constante para a investigação artística em curso.

Buscou-se considerar também a arquitetura como mediadora de experiências limiares: aberto - fechado, interior - exterior, superfície - profundidade, das quais procura-se apreender a sua fenomenologia específica, para observar como as obras artísticas se relacionam com estes termos e de que modo contribuem também para relativizá-los, subvertê-los ou mesmo reforçá-los. 


\section{PESQUISA ICONOGRÁFICA E HISTÓRICA SOBRE A CIDADE DE SÃO PAULO}

Buscou-se, como se disse, um estreito diálogo com memórias e narrativas sobre a cidade de São Paulo. Em um aspecto mais geral, a partir do olhar dirigido à esta cidade, procurou-se refletir sobre a paisagem urbana, sobre as suas transformações e sobre a relação direta entre sujeito, arquitetura e cidade.

As pesquisas bibliográficas e iconográficas relativas à história da arquitetura em São Paulo visaram perceber as modificações sofridas em sua fisionomia. A própria ideia de uma fisionomia é interessante, pois implica que na superfície da cidade são visíveis - ou cristalizam-se - os vestígios de seus processos internos. Fisionomia também pode conotar fachada, permitindo suscitar associações oportunas com superfície exterior, pele, máscara, cenografia, casca. As alterações na fisionomia da cidade de São Paulo são colocadas radicalmente a cada novo "ideal" de cidade: cidade caipira de taipa (da fundação, no século $X V I$, a meados do século XIX), cidade cosmopolita de tijolos (a partir da segunda metade do século XIX e durante as duas primeiras décadas do século $X X$ ), cidade vertical de concreto armado (a partir da década de 1930), como caracterizadas por historiadores da arquitetura e do patrimônio, como Benedito Lima de Toledo, Carlos Lemos e Nestor Goulart Reis Filho; ou, visto de outra perspectiva: cidade escravocrata, cidade de representação da elite cafeeira, cidade industrial e, finalmente, a metrópole contemporânea segregada, conforme caracterizadas por Raquel Rolnik e Candido Malta Campos. 
Temas específicos foram investigados a cada nova necessidade de entendimento das relações possibilitadas pelas obras artísticas: sobre a caracterização do "sítio urbano" paulistano, Aziz Ab'Saber e, por meio dele, relatos de muitas épocas nas citações de Auguste de Saint-Hilaire, entre outros. Sobre as configurações mais gerais que a cidade adotou, representada pelos seus (proto) planos diretores - o Plano Bouvard para a área central (1911), o Plano de Avenidas de Prestes Maia (1930), ou ainda aquele mais utópico de Le Corbusier, registrado em sua passagem pela cidade nos anos 1920, em um único rascunho onde se veem duas enormes avenidas-edifícios que atravessariam a cidade, perpendiculares entre si, para vencer os seus morros e fundos de vale. Sobre as questões históricas referentes às canalizações de nossos principais rios (Tamanduateí, Tietê e Pinheiros) foram observadas a tese de Odette Seabra, referência na área, e as evoluções na cartografia da cidade, em especial o mapa elaborado pela SARA Brasil, em 1930, que atesta uma linha divisória, além da qual os contornos dos rios sofreriam alterações radicais. Outros assuntos de interesse mais geral foram ainda enriquecidos com textos de Hugo Segawa e dos demais historiadores da arquitetura já mencionados.

Diversos acervos de imagens foram também consultados, em especial aqueles capazes de demonstrar enfaticamente os "partidos arquitetônicos" adotados em alguns momentos: o neocolonial do arquiteto Victor Dubugras, de Ricardo Severo e do artista e historiador José Wasth Rodrigues, estilo arquitetônico depois diluído e generalizado na arquitetura residencial, o que Carlos Lemos chamou de neocolonial simplificado; o ecletismo arquitetônico registrado pelas lentes dos fotógrafos Militão Augusto de Azevedo e Guilherme Gaensly, ambos capturaram a cidade no limiar de suas sucessivas modificações; o modernismo pioneiro dos arquitetos 
Victor Dubugras, Flávio de Carvalho e Gregori Warchavchic. Nesta iconografia, registrou-se minuciosamente, por exemplo, as diferentes configurações adquiridas por um mesmo dispositivo, como as janelas basculantes, projetantes e pivotantes, conforme a época e os usos.

O material apresentado para o Exame de Qualificação (depositado em agosto de 2015, exame realizado em outubro do mesmo ano, em mesa composta pelos Profs. Drs. Agnaldo Farias, convidado da FAU-USP, Marco Buti, titular do CAP-USP e pelo orientador Prof. Dr. Luiz Claudio Mubarac, também titular do CAP-USP) concentrava-se em construir uma síntese narrativa deste repertório pesquisado, explorando outros campos do saber relativos à Geografia, ao Urbanismo, à Arquitetura e à História. Objetivava mapear os muitos processos que acabaram por determinar a fisionomia da cidade, para entendê-los, então, como repertórios coletivizados, trocas de experiências amplamente visíveis em nossa arquitetura anônima, popular. Experiências com as quais convivemos diariamente.

Esta síntese teve como função "detonar" e localizar os processos artísticos, ser o ponto de partida e o pano de fundo. A reflexão que se segue, no entanto, concentra-se sobre os aspectos da experiência sensível da cidade, a noção particular de temporalidade e a elaboração dos objetos artísticos. 


\section{A INVESTIGAÇÃO IN SITU E A VIVÊNCIA DA CIDADE}

2007. Segundo semestre, provavelmente. Súbita aproximação ao espaço da cidade. Súbito processo que se torna consciente, deliberado, manipulado intelectualmente. Radical, pois consiste em um "mergulho na noite": vivência de espaços inóspitos para observação dos fluxos e das perspectivas extremas oferecidos por lugares da cidade de São Paulo, tais como vias marginais e pontes sobre o Rio Tietê, além de ruas planas das antigas áreas de várzea da Barra Funda, e ruas das encostas de morros da Casa Verde. Algumas vezes o circuito estendia-se às encostas e partes altas de Perdizes e da Avenida Paulista. Foram excursões solitárias, realizadas durante a madrugada, portando apenas uma bicicleta para o deslocamento e uma mochila que armazenava cadernos artesanais toscos, feitos de papelão e papel manilha rosa de baixa gramatura, e uns poucos lápis de desenho. As pausas para a realização de apontamentos, anotações gráficas, eram imprevisíveis. As anotações se configuravam agressivamente, dada a fragilidade do papel escolhido e as precárias condições do ambiente. Após a realização dos itinerários os desenhos eram continuados no estúdio. Ao papel desgastado, sobrepunham-se novas desagregações, apagamentos e alguns poucos restauros. Atitudes encaradas como elaboração gráfica de um raciocíonio visual que procurava reter a intensidade da vivência anterior.

Até onde é possível "rastrear", a pesquisa artística motivada por situações, narrativas e pela memória da cidade de São Paulo - esta que se busca formalizar como projeto de Mestrado - originou-se nessas excursões, com esses desenhos. 


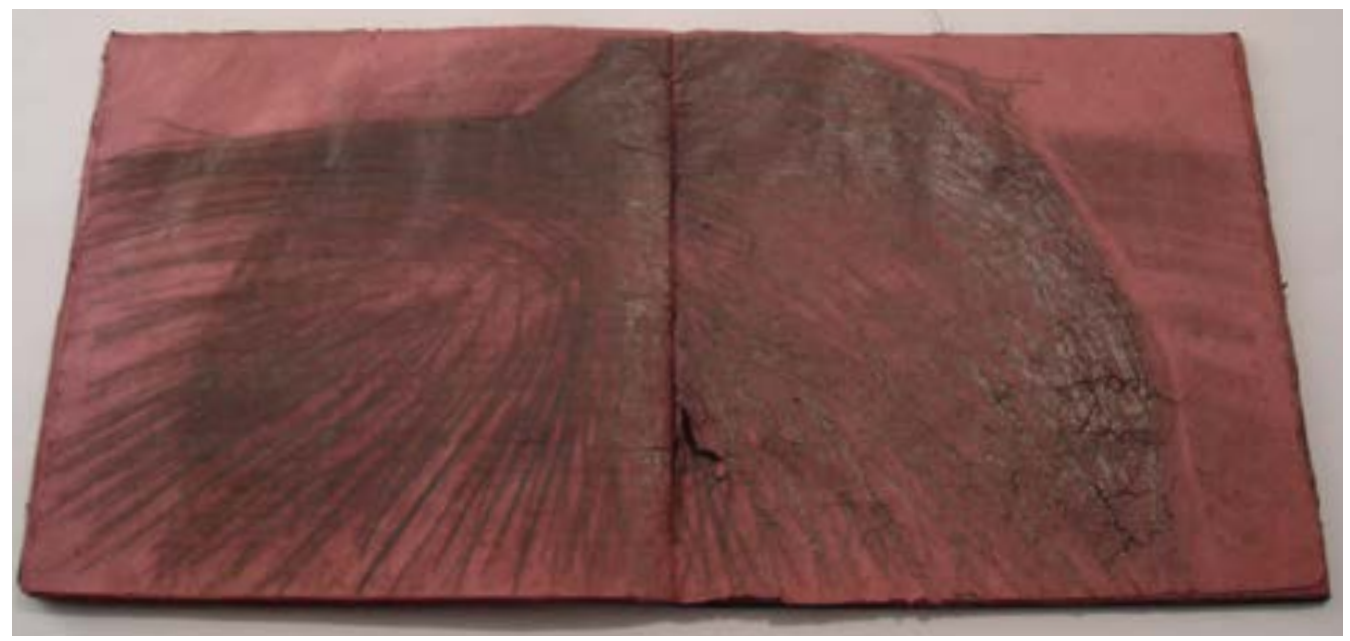

Caderno Noite (Caderno Rosa), 2007

Encadernação manual, capa em papelão, miolo em papel manilha rosa, intervenções com cola, fita adesiva, grafite, lápis oleoso

$20 \times 20 \mathrm{~cm}, 74$ páginas

As desagregações, apagamentos e restauros procedidos nos desenhos, vistos com certo distanciamento, são modos de comentar a própria relação na qual uma parcela da arquitetura popular da cidade se configura: um fazer que sobrepõe repertórios, 
uma acumulação de ideias, de procedimentos, gostos, estilos, que não passam por aprendizados eruditos, mas são motivados por questões mercadológicas, financeiras, preferências pessoais, tudo isto na vivência urgente do dia-a-dia. Mais do que uma falta de erudição, um valor negativo, seria bom crer que essa arquitetura anônima que povoa nossas ruas une uma urgência prática a um espaço para exercício de autonomia, em um proceder que finalmente não se aliena e que tampouco se especializa ${ }^{1}$.

Uma parte substancial da pesquisa foi realizada em excursões diárias, em diversas localidades da cidade. Parte do repertório foi coletado empiricamente e de forma não plenamente sistemática, e posteriormente cruzado com as observações contidas na bibliografia e na iconografia sobre a cidade. Cruzamento esse que permitiu constatar, na dinâmica diária da vida da cidade, as transformações mais sutis e as mais explícitas; observações empíricas que, se não podem ser inteiramente demonstradas, encontram-se no fundo de cada um dos projetos artísticos desenvolvidos.
'Esta sugestão foi dada por Marco Buti durante a sua avaliação no Exame de Qualificação: para o professor, algumas das obras artísticas apresentadas, notadamente aquelas que consistem em vedar portas e janelas pré-existentes com a simples colagem de papel sobre as suas superfícies, poderiam estar referidas nesses procedimentos não especializados, autônomos, em grande parte motivados por necessidades empíricas, capazes, contudo, de detonar processos criativos. A meu ver, a radicalidade desta sugestão é que, no limite, também a arte deixa de ser uma atividade especializada do pensamento para ser motivada por necessidades criativas concretas a partir de situações imprevistas nos códigos artísticos tradicionais. Deixa de ser um lugar de especificidades e abre-se para enfrentar novos modos de produção e discurso. 


\section{A INVESTIGAÇÃO SOBRE ALGUNS ELEMENTOS DA ARQUITETURA, A PARTIR DE SUA FENOMENOLOGIA}

"... o limiar parece ter adquirido uma tal espessura que dele não se consegue sair"2

A etimologia da palavra janela nos indica:

"(...) deriva do latim vulgar januella, diminutivo de janua (ou ianua) que designava a porta, passagem, entrada, acesso. Já jãnus (iãnus), substantivo masculino, designa passagem, arcada, pórtico ou galeria abobadada no fórum (...) Porém, Jãnus (ian), substantivo próprio masculino (Jano) era a divindade das portas de passagem. Foi um dos principais deuses romanos, e dos mais antigos, chamado "deus dos deuses" no hino dos sálios. Era o primeiro deus a ser mencionado nas preces, e o primeiro a receber a porção do sacrifício. Jano é mencionado também como o guardião do universo, o abridor e fechador de todas as coisas, olhando para dentro e para fora da porta, e passou a ser o deus dos inícios [janeiro, por exemplo] (...) e de todas as aberturas. Do mesmo modo que as aberturas realizadas num muro unem dois espaços, o de dentro e o de fora, Jano era representado com duas faces (bifrons), uma voltada para frente e a outra para trás, sugerindo vigilância constante ou simbolizando sua sabedoria, como conhecedor do passado e adivinho do futuro." (JORGE, 1993, p. 5-6)

\footnotetext{
2Jeanne Marie Gagnebin, "Entre a vida e a morte" In George Otte et al, Limiares e Passagens em Walter Benjamin, Belo Horizonte: Editora UFMG, 2010.
} 
Ao muro é conferida a propriedade de parcelar e limitar o espaço. Janelas e portas oferecem experiências de limiar.

"A porta, como as duas faces de Jano, representa o ser em trânsito, permeabilidade e reversibilidade, a decisão regida pela dialética do abrir e do fechar", nos diz Luís Antonio Jorge (1993).

Uma janela, conforme sugere o arquiteto Rem Koolhaas (2014) ${ }^{3}$, tem como propriedades promover e modular a luminosidade de um ambiente, enquadrar (framing) a paisagem exterior, mediar o olhar externo que se volta para dentro; dispõe-se para a fenomenologia do aberto e do fechado, do dentro e do fora, do íntimo e do coletivo; propõe lugares no espaço arquitetônico que promovem experiências específicas, conforme a sua localização no edifício, dimensões e tipologias. Sua presença na arquitetura se modifica no tempo: das pequenas frestas presentes nos zigurates e pirâmides - onde há um predomínio das massas, cheios sobre vazios, interrompido somente a partir do século XV, na Europa, com o desenvolvimento da vida urbana no Renascimento (JORGE, 1993) - aos edifícios superexpostos, iniciados com os palácios de cristal das exposições universais no século XIX (talvez possamos incluir o Panóptico nesta categoria, que data do fim do século XVIII), e com os panos de vidro que atravessaram todo o modernismo arquitetônico (Mies van der Rohe, Walter Gropius) apegados ao ideal ético de transparência4.

A noção de vão e de janela se transformou - e foi esgarçada - até o ponto no qual, contemporaneamente, uma janela pode prescindir de seu aparato retórico manifestado por sua caixilharia. A janela dilui-se na estrutura geral da arquitetura. A tecnologia para o emprego do vidro tem permitido o controle de enormes dimensões, de maior resistência, transparência e até são usados artifícios 
sofisticados para o controle térmico. Numa relação de continuidade visual, diferenças entre espaços interiores e exteriores deixam de existir, "mais e mais janelas oferecem uma visão do mundo, mas não uma conexão física com ele" (KOOLHAAS, 2014, p.607).

As barreiras e membranas parecem desaparecer. Um efeito ilusório, já que os demais componentes da experiência sensível diferenciam-se radicalmente quando expostos aos ambientes externos e internos, mesmo que estas noções (dentro - fora, aberto fechado) sejam colocadas à prova no contexto oferecido pela internet e pelas redes sociais.
3 Trata-se dos volumes de Elements of architecture, elaborados por Koolhaas em colaboração com seus alunos de graduação da escola de design de Harvard, e outros pesquisadores associados, por ocasião da curadoria que o arquiteto realizou para a Bienal de Arquitetura de Veneza, em 2014. Agradeço ao professor Agnaldo Farias por ter chamado a minha atenção para este material.

${ }^{4}$ Décio Pignatari, em seu texto de apresentação da publicação da dissertação de mestrado de Luís Antonio Jorge (seu orientando), assim sintetiza este percurso histórico: "Do templo grego sem janelas ao arranha-céu só feito de janelas, assiste-se ao extraordinário processo de a parte virar o todo" (JORGE, 1995, p. 11). Quanto ao ideal ético de transparência aqui sugerido, Argan nos diz a respeito de edifícios de Gropius e Mies: "A razão prática para o máximo de ar e luz nos laboratórios [da Bauhaus] apresenta um aspecto ideológico: numa comunidade democrática "as casas são de vidro", nada se esconde, tudo se comunica", e continua Argan: "(...) a "casa transparente" que chega até o céu, utopia expressionista, morada do homem que não tem nada a esconder, símbolo da consciência pura, da vida consagrada a um ideal" (ARGAN, 1992 , p. 392 e 397). Vale contrapor ao que nos diz $\mathrm{Hal}$ Foster a respeito da arquitetura contemporânea: "Consideremos a transparência. Mais uma vez, como seus predecessores modernos, a Foster [and Partners, escritório do arquiteto contemporâneo Norman Foster] insinua uma analogia entre abertura arquitetônica e política (...) No entanto, a analogia é duvidosa desde o começo (...) Como podem os arquitetos continuarem a vender essa linha? (...) Seria por uma ligação sentimental com as antigas virtudes da transparência e pela vã esperança de que, ao parecer transparente, chegará a sê-lo? (...) o que antes parecia transparente pode agora parecer espetacular, a luz e o vidro não significando mais tanto responsabilidade cívica quanto atrativo para as massas" (FOSTER, 2015, p. 69). 
Essa diluição na estrutura da arquitetura é também percebida na ausência física de um aparato que seja caracterizado como uma porta. Em um aeroporto, por exemplo, a porta é parcelada em inúmeros dispositivos com a função de impor obstáculos, tais como filas, scanners de bagagem e scanners corporais, detectores diversos, vistorias feitas por técnicos, policiais armados e cães farejadores, etc.

O gesto banal de atravessar uma estação como o Terminal Barra Funda, em São Paulo, nó de comunicação entre linhas de metrô, ônibus (municipais e intermunicipais) e trens, atesta a ausência de um dispositivo que possa ser enfaticamente caracterizado como uma porta. Experiências de limiar são distribuídas por diversas rampas, escadas - rolantes ou não -, ramais de conexão, corredores, catracas, filas, grades, plałaformas, e são ainda mediadas por seguranças uniformizados armados, inúmeras placas de informações, lojas, máquinas de autoatendimento. Em outras estações do metrô de São Paulo atividades artísticas são objeto de uso utilitário cuja função é distrair, entreter os usuários numa lógica de administração do tempo e do fluxo nas estações.

Portas e janelas carregam também diferenças simbólicas que insistem nas noções de dentro e fora. Se a transparência da janela pode ser interrompida, permitindo modos mais ou menos explícitos de dirigir o olhar para o outro lado (por isso apresenta, em sua iconografia, metáforas sobre a castidade feminina), a porta se realiza somente quando é possível ser atravessada pelo corpo. Para além da experiência do bloqueio e da sua opacidade, fundamenta-se na experiência do atravessamento, do arco, do portal e do batente (daí a sua associação com Cristo, conforme mostra Rem Koolhaas, e com os ritos de passagem). Pressupõe-se, simbolicamente, a mudança radical de mundos ao cruzar uma porta. 
"Nós nos tornamos muito pobres em experiências de limiar (...) É preciso distinguir cuidadosamente o limiar da fronteira. O limiar é uma zona." ${ }^{5}$

Zona intermediária. Lugar de detenção e estancamento - suspensão - e simultaneamente de atravessamento. A experiência dos vãos arquitetônicos enfatiza elementos de separação e de passagem, de reversibilidade e permeabilidade, de diferença entre o que está em cada um dos lados dos dispositivos. Ao analisar noções de limiar em Walter Benjamin, Jeanne Marie Gagnebin traça os sentidos do termo em alemão (schwelle) - aquilo que se coloca entre dois elementos, obstáculo e passagem - e do termo em latim (limen, liminis, de onde derivam seuil e linteau) - viga ou lintel que sustenta as paredes de uma porta6.

Pretende-se com as obras artísticas ressaltar essas ambivalências, ou confundi-las, insistindo em elementos de pura exterioridade - é sempre bem-vindo o uso dos termos fisionomia, pele, superfície, fachada, casca. Contudo, a pura exterioridade a que se quer aludir aqui não exclui a existência de um interior, na verdade, confunde-se com ele, ou dele é vestígio.

Convém evocar o conceito de "ser entreaberto" de Gaston Bachelard (2008), no qual ideias de amplitude e espaço compacto (íntimo), são invertidas: o espaço interior passa a ser tão ameaçador e abissal como o amplo lado de fora; e no sentido contrário, há uma compactação descomunal do espaço exterior, gera claustrofobia. $\bigcirc$ "ser entreaberto"

${ }^{5}$ Walter Benjamin, Le livre des passages, p.512513, como citado em Georges Didi-Huberman, Diante do tempo, Belo Horizonte: Editora da UFMG, 2015, p.126.

${ }^{6}$ Jeanne Marie Gagnebin, op. cit., 2010, p. 14. 
das janelas e das portas faz com que tornem-se membranas intermediárias, por vezes reforçadas, por vezes diluídas. Ao manter-se esta relação de reversibilidade - mais do que buscar uma síntese - entre o aberto e o fechado, a experiência torna-se mais complexa, instável, heterogênea.

"Há superfícies que transformam o fundo das coisas ao redor (...) Podemos pensar que a superfície é o que cai das coisas: que advém diretamente delas, o que se separa delas, delas procedendo, portanto."7

Lembro-me de visitar Dzibilchaltún, um sítio arqueológico da região de Yucatán, no México, em 2010, durante uma residência artística, numa data de equinócio, e observar um fenômeno que se repete ali por aproximados 2.500 anos. Ao raiar do dia, o sol se levanta no horizonte. À sua frente posiciona-se uma arquitetura cúbica, instalada sobre uma base piramidal com escadas (mais alta que a linha do horizonte), tendo uma espécie de cume igualmente piramidal, coerente com as tipologias elaboradas pela civilização maia para seus templos e monumentos. Esta arquitetura, con-
${ }^{7}$ Georges Didi-Huberman, Cascas (2011), In Revista Serrote, n. 13, São Paulo: Instituto Moreira Salles, março 2013, p.131-132. 
tudo, é dotada de portas em todos os lados, alinhadas. Através delas é possível testemunhar o sol passar precisamente por esses vãos. Centralizado, calculado, perfeito. Sincronia que pode ser vista frontalmente com esta riqueza a uma distância de ao menos dois quilômetros. Mas ao atravessar a abertura dos vãos, ocorre um fenômeno visual inesperado (para mim, ao menos): o sol é contido dentro desta arquitetura que funciona como um obturador fotográfico. Neste momento, noções de grandeza (pequeno-grande) e de espaço (dentro-fora) são totalmente desagregadas.

Esta visita à Dzibilchaltún resultou em um vídeo, Magenta (2010), que procura reconstituir o fenômeno, transformado em uma especulação acerca de um suposto objeto artificial preto e espelhado que ora eclipsa uma fonte de luz magenta, ora a revela. O tema do espelho é sempre latente na prática artística em curso.
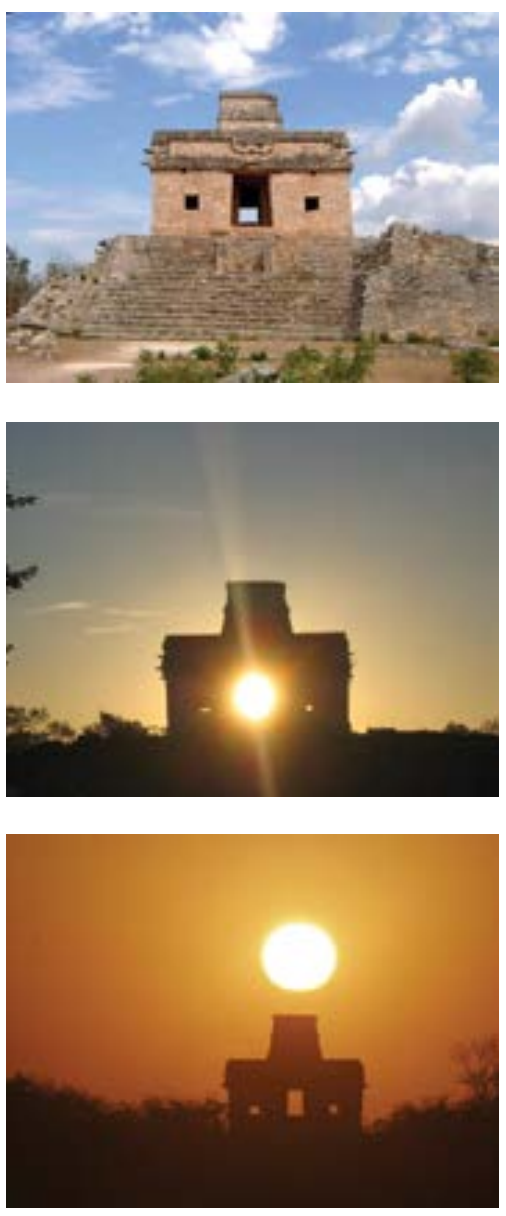

Dzibilchaltún, Mérida, Yucatán, México

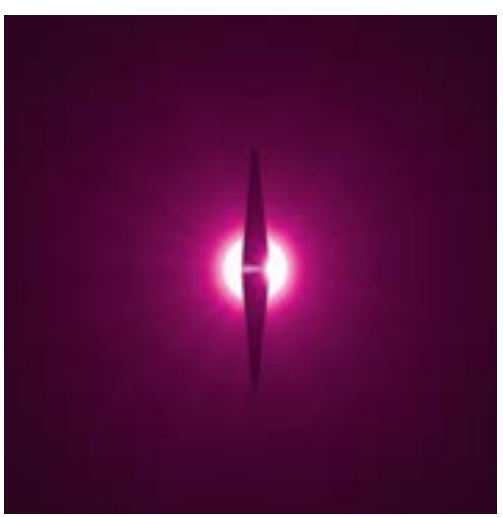

Magenta, 2010, animação digital, 3 min, colaboração: ZoomB. 
As imagens desta arquitetura arqueológica mexicana evocam também muitas atitudes contemporâneas de artistas que provocam ambiguidades a partir das diferenças de contexto, escala e temporalidade entre espaços internos e externos. Poderíamos citar a conhecida obra de Olafur Eliasson realizada no interior do Turbine Hall, da Tate Modern (The Weather Project, 2003), por sua semelhança formal imediata com o fenômeno visto na ruína de Dzibilchaltún. Ou ainda evocar obras que, em retrospectiva, incluiriam artistas como Richard Serra, Robert Morris, Robert Smithson, Michael Heizer, Walter De Maria, especialmente mencionados pelos trânsitos que realizam entre o ambiente aberto da terra (land) e o interior do espaço expositivo. Mas também Gordon Matta-Clark (especialmente os projetos em que realizou cortes em arquiteturas) e James Turrell. Deixando o repertório norte-americano, poderíamos indicar Anish Kapoor, que problematiza fundamentalmente ideias de grandeza, interioridade e exterioridade, virtualidade e experiência concreta, algumas obras de Cildo Meireles e também, com muita propriedade entre nós, Artur Lescher, Marcius Galan e Rubens Mano. Por fim, o artista Tatzu Nishi, japonês radicado em Berlim, que promove, a partir de informações próprias ao ambiente urbano, trocas e inversões de referenciais, de onde resultam distorções em ideias de público e privado, monumento e artigo doméstico estereotipado (kitsch).

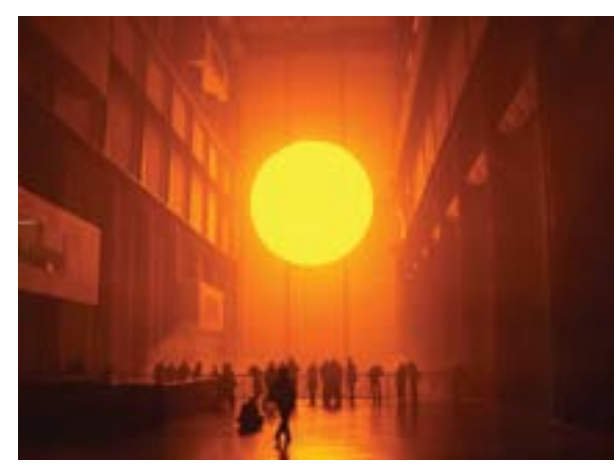

Olafur Eliasson, The Weather Project, 2003 


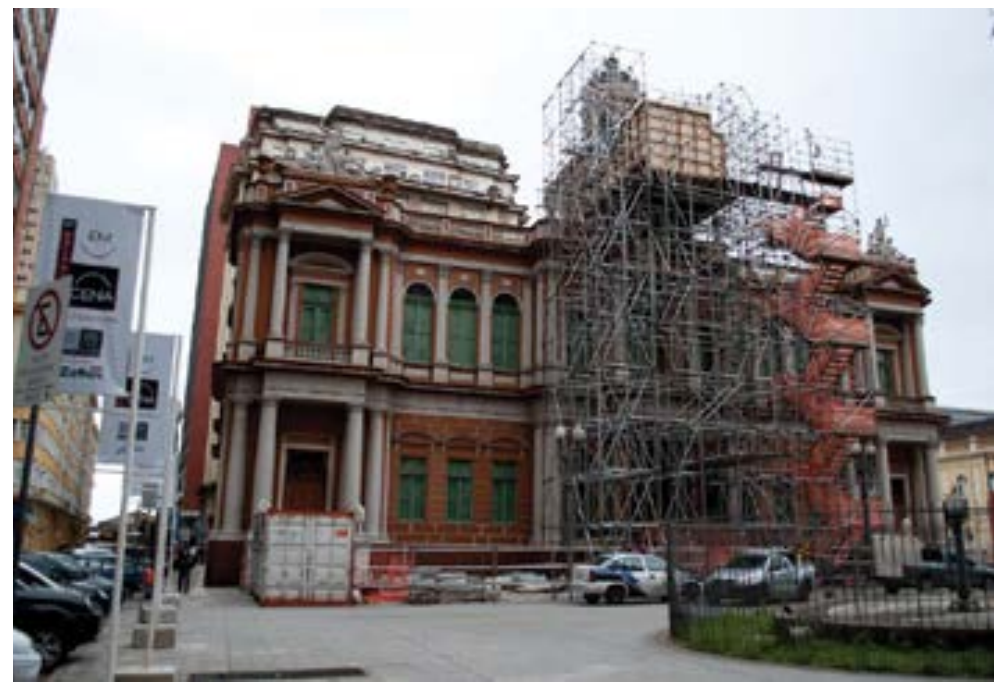

Tatzu Nishi. Intervenção na fachada frontal da prefeitura de Porto Alegre, 8 Bienal do Mercosul, 2011. Andaimes sustentam um cômodo provisório localizado junto ao topo da fachada da prefeitura. $\mathrm{O}$ acesso ao cômodo é feito pelas escadas no andaime.

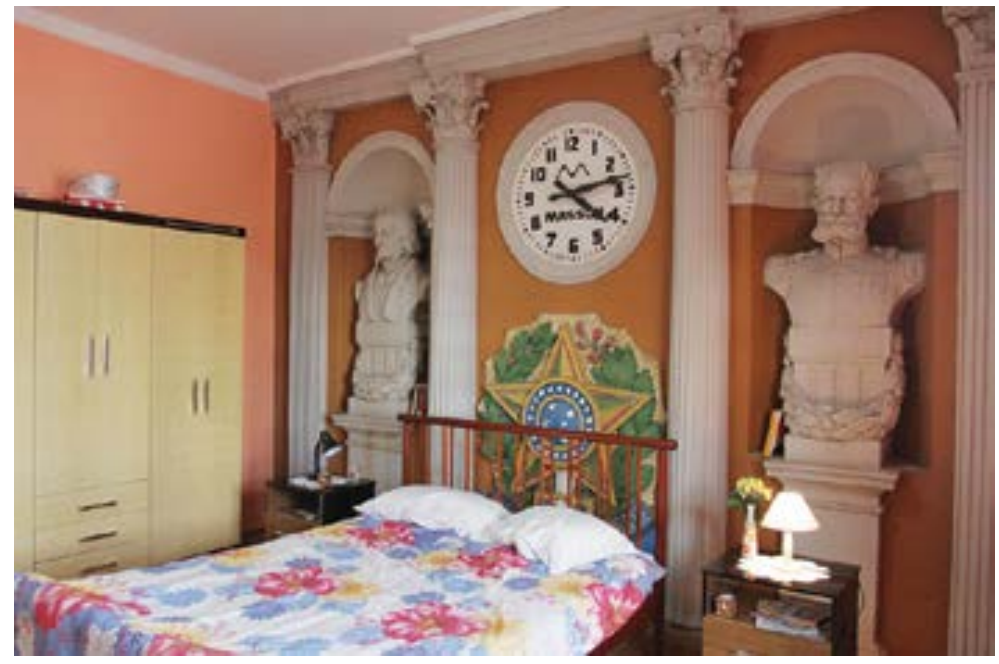

Tatzu Nishi. Vista interna da instalação. Ao fundo vê-se relógio, bustos de José Bonifácio e Marechal Deodoro da Fonseca, colunas e o escudo da República brasileira, que formam os detalhes da fachada. 


\section{ESPAÇOS DE SILÊNCIO}

"Timelessness is found in the lapsed moments of perception, in the common pause that breaks apart into sandstorm of pauses." 8

Espaço de silêncio é o termo que tenho utilizado para definir experiências análogas àquelas vividas em ruínas arquitetônicas e em espaços deliberadamente construídos nos quais apresenta-se uma descontinuidade temporal. Trata-se de um conceito que se pretende operativo, ou seja, em função do desenvolvimento de meus próprios projetos artísticos.

Existem alguns tipos de ruínas: as zonas arqueológicas ou históricas, as casas abandonadas, as casas vazias. Podem ou não estar inseridas em núcleos urbanos. O que caracteriza uma ruína não é exatamente o estado de deterioração de suas estruturas, mas o fato de que essa estrutura não tem uma função ativa em seu contexto, deixa de existir para a experiência contemporânea do lugar. Todos os seus referentes / índices vivem no passado.

Um observador submetido a espaços como esses precisa lidar com referenciais que não são reconhecíveis em sua experiência cotidiana, ou que o são, mas de modo incompleto. Sua percepção torna-se mais sensível, entra em um estado de atenção, e a percepção da passagem do tempo também se modifica. $O$ tempo dilata, funciona em outra lógica.

\footnotetext{
${ }^{8}$ Robert Smithson, "Incidents of Mirror-Travel in the Yucatan" (1968), In Nancy Holt (org.) The Writings of Robert Smithson, New York: New York University Press, 1979, p. 96.
} 
O passado atravessando o presente. Sobrevivências. Descontinuidades temporais. Presente suspenso. Captura da percepção. A ruína arquitetônica pode oferecer-nos uma variedade de experiências cuja temporalidade e espacialidade aparecem de algum modo alteradas, deslocadas de sua percepção habitual.

Impõe-se uma descontinuidade temporal. "As ruínas", segundo Olgária Matos, "contrariam o devir abstrato do tempo, compensando a sistemática tripartição - antes, durante, depois - pela dinâmica pas encore (ainda não) e jamais plus (nunca mais): as ruínas ocupam um justo meio entre o desmoronamento total de uma linha, por assim dizer, inteira; este justo meio se mantém em equilíbrio, em suspenso; permite estabelecer um elo de transitoriedade com o mundo para o qual chegou a hora final (...) Instante único, elas atestam um tempo antes do qual nada foi consumado e depois do qual tudo está perdido"9.

É o "momento sem antes nem depois", a partir do qual se produz uma espécie de vertigem, de pausa. Lugar do devaneio - para o futuro e para o passado - onde impõem-se relações paradoxais: "Ruínas agregam um conjunto de paradoxos temporais e históricos. Os edifícios em ruína são vestígios e portais para o passado; sua decadência, um lembrete concreto sobre a passagem do tempo (...) Ao mesmo tempo, a ruína nos lança adiante no tempo; prediz um futuro no qual o nosso presente cairá em semelhante decadência ou vítima de uma imprevisível calamidade. A ruína, apesar do estado de deterioração, de algum modo sobreviverá a nós. E o olhar que dirigimos às ruínas é um modo de nos desprendermos das garras de cronologias pontuais, deixando-nos à deriva no tempo"10.

9 Olgária Matos, Vestígios, São Paulo: Palas Athena, 1998 , p. 83.

${ }^{10}$ Brian Dillon, Ruins - Documents of Contemporary Art, Whitechapel Gallery (Londres) e MIT Press (Cambridge), 2011, p. 11. Tradução nossa. 
Um modelo temporal possível para esta imagem do tempo descontínuo da ruína seria o caleidoscópio. Tem-se uma linha com três pontos: passado, presente e futuro. Esta linha flutua no ambiente espelhado do caleidoscópio, esta estrutura "maliciosa", no dizer de Didi-Huberman. A linha será multiplicada ao infinito, fragmentada, suspensa e atravessada por outras linhas iguais. Os pontos referenciais do tempo serão explodidos, fundidos, estilhaçados. Basta que a percepção possa organizar esta imagem, criar alguma estabilidade, e o instrumento sofrerá uma rotação, desestabilizando e fragmentando novamente todos os pontos. O caleidoscópio serve de analogia ao modelo temporal da ruína, no interior da qual o tempo linear, homogêneo deixa de existir.

Uma passagem do artista Robert Smithson em A Tour of the Monuments of Passaic, New Jersey é particulamente reveladora a respeito de um tipo de experiência que se assemelha ao modelo aqui proposto pelo caleidoscópio:
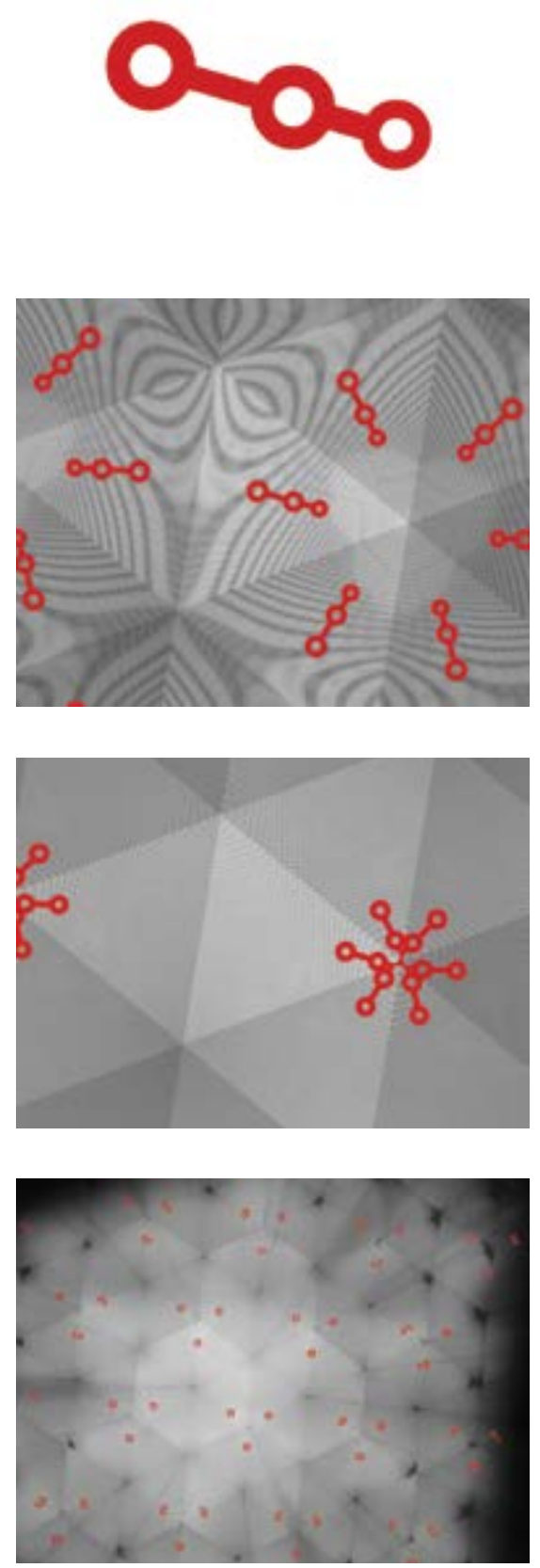
"Desci por um terreno de estacionamento que cobria (covered) os velhos trilhos da estrada de ferro, trilhos que algum dia cortaram Passaic. Esse monumental terreno de estacionamento dividia a cidade em duas, transformando-a num espelho e no seu reflexo mas o espelho ficava trocando de lugar com o reflexo. Nunca se sabia em qual lado do espelho se estava".11

Faz-se alusão à estranha paisagem em ruínas de Passaic, onde o artista observa a velha cidade sendo substituída, mas não inteiramente, pela nova cidade. Os movimentos de água - conduzida por largos canos - de terra - buracos no solo -, e o maquinário utilizado para as alterações urbanísticas geram um cenário de destruição, inumano. Suscitam no artista desconfiança em relação ao futuro. Os carros novos reluzentes e os carros usados espelham-se e trocam de lugar: futuro e passado intercambiáveis. Um antecipa o outro em sua obsolescência. Confrontrados, desdobram-se ao infinito, como dois espeIhos que se entrevêem. $O$ espelho do qual nos fala Smithson é o das "ruínas às avessas", ruínas "antiromânticas", estruturas que "não desmoronam em ruí- nas depois de serem construídas, mas se erguem em ruínas antes mesmo de serem construídas"12.

Descontinuidades serão ainda exploradas por Smithson em outro texto, Incidents of Mirror-Travel in the Yucatan, no qual noções de infinidade e de reflexos sucessivos propõem acesso ao tempo paralisado (timelessness), à ausência de duração, aberturas para o passado pré-histórico, cuja experiência temporal não pode ser narrada a partir de uma perspectiva antropológica, mas em eras, no domínio dos cataclismas, dinossauros, formações rochosas, erupções vulcânicas. "São as coisas mortas há muito tempo, com efeito, que assombram com maior eficácia - da maneira mais perigosa - a nossa memória", nos diz Didi-Huberman (2013, p.69).

"Robert Smithson, "A Tour of the Monuments of Passaic, New Jersey" In Nancy Holt, op. cit. 1979, p. 56 (Tradução nossa com base em uma tradução de Pedro Sussekind, Revista Temáticas n.19, encontrada online).

12/dem, p. 54 (grifos do autor). 
Ao localizar espelhos em paisagens aparentemente inexploradas, Smithson promove descontinuidades espaciais e temporais, "furos" no fluxo homogêneo do tempo e do espaço, diluindo definições claras entre alto e baixo, dentro e fora. "O deslocamento estava no chão e não sobre o chão", pontua o artista13. "Desenho anacrônico ... [reúne] num mesmo plano de inscrição o tempo pessoal, quase anedótico, de uma excursão em pequena escala, e o tempo impessoal, gigantesco, de uma erosão em larga escala" (Didi-Huberman, 2013, p.122). Tempo da experiência pessoal, tempo primordial e tempo final reunidos num mesmo ponto de interseção, o presente suspenso.

"Por que os espelhos apresentam uma conspiração de silêncio acerca de sua própria existência? Quando deslocamento [displacement] se torna extravio [misplacement]? (...) Espelhos progridem em silêncio, e geram incapacidade. Reflexos caem dos espelhos sem lógica (...) invalidam qualquer afirmação racional. ${ }^{14}$

Olhando retrospectivamente - e autorizando-me fazer uma breve digressão - Big Bang, da série Natências (2009), a introdução do vídeo SOMNUS (Noite São Guálter) e Magenta (ambos de 2010), Caleidoscópio e as imagens da série Primary Mirror (ambos de 2012) são exemplos de obras nas quais pude explorar o espelho como objeto da representação. Serviram de ponte sensível - local de atravessamentos - entre a temporalidade da experiência pessoal e temporalidades cósmicas (enfatizadas também pelas trilhas sonoras dos vídeos), escalas de tempo ampliadas. Atravessamento para outros mundos.

${ }^{13} /$ dem, p.95. Tradução nossa (grifos do autor).

14 Idem, p.97. Tradução nossa. 

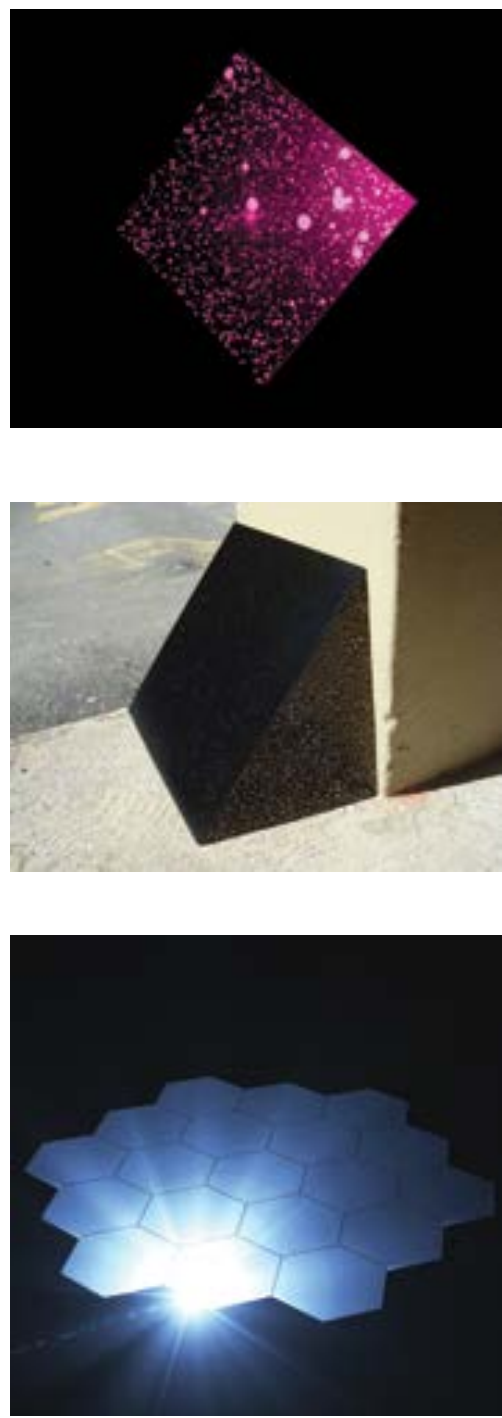

Primary Mirror, 2012 Imagem digital

Dimensões variáveis

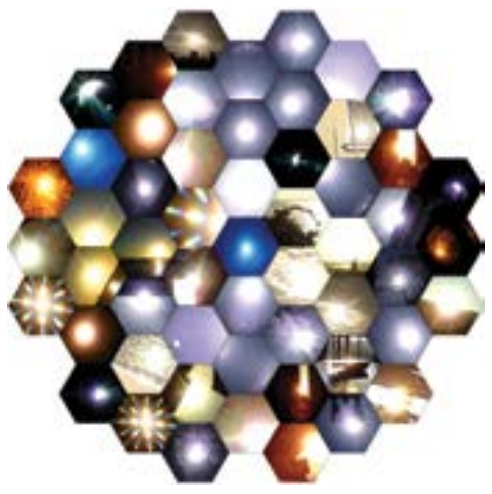

Caleidoscópio, 2012 Imagem digital

Dimensões variáveis
SOMNUS (Noite São Guálter), 2010

Animação digital

8 min

Colaboração ZoomB

S/ título, 2009

Fotografia

Dimensões variáveis 
A experiência da ruína é fragmentária, sucessão de descontinuidades. É, assim, necessariamente incompleta. Abre-se à significação fora de seu contexto: "o que jaz em ruínas, o fragmento significativo, o estilhaço", diz Water Benjamin. O autor afirma que a imagem do passado é inteiramente formada por ruínas: os "despojos" do passado se acumulam frente ao anjo da história, atônito, que é fortemente impelido para o futuro pela tempestade do progresso. Caberia ao historiador, mas também ao crítico, ao "pintor da vida moderna", ao colecionador e ao flâneur resgatar esses despojos no instante fugaz no qual se apresentam ao presente: "apropriar-se de uma reminiscência tal como brilha no instante de um perigo" (Didi-Huberman, 2015, p.113). É uma coleção de estilhaços temporais, um modelo de tempo anacrônico, "intensivo", no qual sobrevivem muitos "agoras"15.

Este modelo anacrônico do tempo é um "modelo fantasmal"16. Fantasmas: eventos do passado que não "param de sobreviver"17, conforme nos fala Didi-Huberman. Para o filósofo, a imagem tem uma natureza fantasmal, lugar onde se acumulam fósseis de eventos imemoriais há muito esquecidos ou recalcados, destruídos pelo tempo e pela História. Como fósseis do tempo, os fantasmas estão latentes, o que significa afirmar que o passado não cessa de fluir sobre o presente, que o contemporâneo é essencialmente anacrônico, lugar de muitos "agoras", vale insistir novamente.

${ }^{15}$ Vocabulário e citações provenientes de Walter Benjamin, Sobre o conceito de História, In Walter Benjamin: Magia e técnica, arte e política - ensaios sobre literatura e história da cultura, Obras escolhidas v.1, São Paulo: Editora Brasiliense, 1993, p. 222 a 232 .

${ }^{16}$ Georges Didi-Huberman, op. cit., 2013, p. 25

$17 /$ dem, p.29. 
Como experimentamos essas sobrevivências? Questão dirigida às ruínas. Errância no tempo: quando "deslocamento" (displacement) se torna "extravio" (misplacement) ${ }^{18}$, "síncope num movimento ou num devir", "corte rítmico [que] abre os espaços dos fósseis antes da história"19.

Errância - extravio - governada pela memória, pela capacidade de rememoração, pelas reminiscências suscitadas pelos "despojos" do passado. "A memória está", nos diz Didi-Huberman, "nos vestígios que a escavação arqueológica traz à tona; mas está também na própria substância do solo, nos sedimentos agitados pela enxada do escavador; está, enfim, no próprio presente do arqueólogo, no seu olhar, nos seus gestos metódicos ou hesitantes, na sua capacidade de ler o passado do objeto no solo atual."20

Smithson refere-se, em muitos textos e obras, ao "tempo geológico", que se revela ao olhar nos canteiros de obras das cidades (em Passaic, ou no Central Park, em Nova York) e em lugares ainda inabitados (florestas em Yucatán): "a paisagem se rebobina nos milhões e milhões de anos de "tempo geológico"'." Em seu modo de ver, arquitetura e urbanismo são sinais de um processo que fatalmente se encaminha para a entropia.

Em seu sentido científico, entropia consiste no processo irreversível de perda de energia. Aplicada às ciências humanas, descreve a desvitalização da experiência temporal frente ao presente governado por imperativos de funcionalidade, alta performance produtiva e objetividade 21 . Aplicada à arte, tal como caracterizada por Robert Smithson, a entropia é o modo de articulação de tempos heterogêneos, para enfatizar ou repudiar o presente: os "novos monumentos", nos diz, "não são construídos para as eras, mas contra elas.

${ }^{18}$ Robert Smithson In Nancy Holt, op. cit. 1979, p. 97.

${ }^{19}$ Georges Didi-Huberman, op. cit., 2015, p.129.

20 Georges Didi-Huberman, op. cit., 2015, p. 122-123.

21 Olgária Matos aborda o assunto nos seguintes termos: "Esse fenômeno é conhecido, desde Marx, como alienação (...) tempo que é o presente repetitivo de um único gesto do trabalhador no processo produtivo" (MATOS, 1998, p. 29-30); "Se, no trabalho, a proletarização é perda do saber-fazer, o consumo alienado é perda do saber-viver, é perda do tempo". 
Estão envolvidos numa sistemática redução do tempo à frações de segundos, ao invés de representar os longos espaços dos séculos. Ambos, passado e futuro são localizados num presente objetivo. Este tipo de tempo contém pouco ou nenhum espaço; é estacionário e imóvel (...) é contra as voltas do relógio"22.

\section{Contra o tempo do relógio!}

Imobilidade, congelamento, monotonia, insipidez e letargia são alguns dos termos encontrados em textos de Smithson para descrever a descontinuidade radical do locus temporal. Perda de energia, des-arquiteturização, regresso à eras glaciais: na entropia, "a energia é mais facilmente perdida que obtida, e num futuro derradeiro todo o universo se esgotará e será transformado em abrangente monotonia [sameness]"23. Atesta-se a condição de obsolescência do seu presente e do seu futuro: "não desmoronam em ruínas depois de serem construídas, mas se erguem em ruínas antes mesmo de serem construídas"24, cabe repetir. "Evolução ao contrário"25, portanto. Essas parecem ser as impli- cações complexas da temporalidade de um ambiente em ruínas. O tempo parece revestir-se de uma "pressão" (Tarkovski) ${ }^{26}$, e sua consistência se modifica.

Temporalidades descontínuas podem também ser instauradas, deliberadamente, em espaços construídos, e não são somente resultado de um deslocamento temporal do ambiente em ruínas, tal como se observa em espaços projetados pelo arquiteto mexicano Luis Barragán (1902 - 1988) e pelo arquiteto japonês Tadao Ando (1941). Ambos criam espaços silenciosos de "evocação poética que transcendem as características cotidianas de lugar"

22 Robert Smithson In Nancy Holt, op. cit. 1979, p.10.

${ }^{23}$ Robert Smithson In Nancy Holt, op. cit. 1979, p.9.

${ }^{24}$ Idem, p. 54 (grifos do autor).

25 Idem, p. 9.

${ }^{26}$ Andrei Tarkovski elabora um complexo raciocínio sobre o tempo como material plástico, dotado de qualidades psíquicas que the conferem diferentes densidades. "O tempo específico que flui através das tomadas cria o ritmo do filme, e o ritmo não é determinado pela extensão das peças montadas, mas sim pela pressão do tempo que passa através delas (...) A consistência do tempo que corre através do plano, sua intensidade ou "densidade", pode ser chamada de pressão do tempo." Andrei Tarkovski, Esculpir o tempo, São Paulo: Martins Fontes, 2002, p. 139. 
(TREIB, 2001, p.118). Capturam a percepção do observador em um duplo movimento de concentração da experiência e distenção temporal. Espaços amplos com estruturas inertes onde o tempo é imposto pela trajetória do corpo que se move ali. Pode-se mesmo afirmar que o tempo advém deste deslocamento do observador, desta presença física que move-se com cuidado, absorvendo cada transição luminosa, registrando cada alteração nas superfícies. Os espaços destes arquitetos parecem almejar experiências de transcendência. Aproximam-se das experiências de religiosidade e meditação, em seus atributos de silêncio e pausa. Isso é facilmente observado em suas obras mais icônicas: a Capela das Monjas Capuchinas (Tlalplan, Cidade do México, 1954-60) de Barragán, e as igrejas de Tadao Ando, Igreja sobre a água (Shimukappu, Hokkaido, Japão, 1988) e Igreja da luz (Ibaragi, Osaka, Japão, 1989), além do templo budista construído por Ando, o Templo da Água (Awají, Hyogo, Japão, 1991). Outras obras dos arquitetos sem fins religiosos insistem nessas atmosferas inertes, ricas em ambiguidades, fazendo uso de vitrais coloridos, luzes indi- retas, efeitos cromáticos, da superfície reflexiva de espelhos d'água e de extensas superfícies monocromáticas e homogêneas - enormes massas com cores saturadas, nas arquiteturas de Barragán, e as lisas superfícies silenciantes de concreto armado dos edifícios de Tadao Ando27.

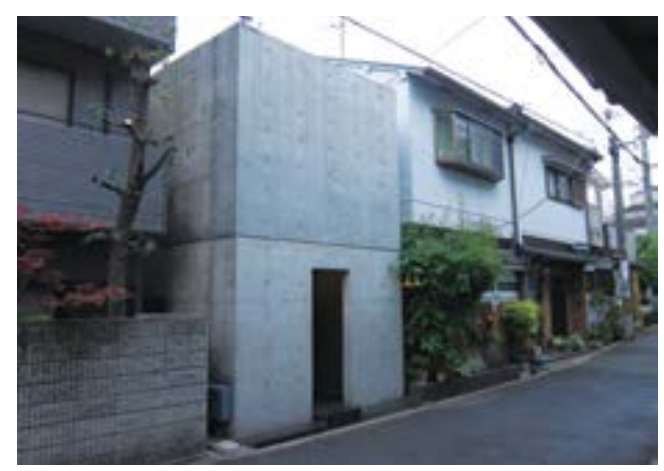

${ }^{27} \mathrm{~A}$ poética do arquiteto japonês insiste na elaboração deste tipo de superfície cinza, lisa, homogênea, capaz de impor pausas visuais e sedução tátil. É evidente em um de seus primeiros projetos, a Row House (Sumiyoshi, Osaka, 1975 - 1976), uma ruptura na continuidade visual das fachadas, provocada pela extrema economia de seu desenho. No entanto, o contraste radical faz-se sem alarde, de um modo discreto até, o que confere ao edifício uma presença especial, limiar entre pertencer ao conjunto de casas e extraviar-se dele. 
Pude visitar muitas das arquiteturas realizadas por Barragán na Cidade do México, e tive a oportunidade única de visitar uma exposição com desenhos de seus projetos - alguns deles, inclusive, realizados em serigrafias com diversas camadas de cores - e com maquetes, sofisticados mecanismos capazes de simular efeitos luminosos esperados pelos vitrais coloridos, característica marcante de sua arquitetura. A experiência dos espaços construídos pelo arquiteto mexicano foi fundamental para pensar a relação de descontinuidade espacial e temporal que resulta nesta suspensão do tempo, na manipulação do silêncio.

Quanto à vasta obra de Tadao Ando, ao visitar alguns de seus edifícios no Japão, pude notar que os seus espaços são impregnados de temporalidade própria. Especialmente naquelas arquiteturas que se destinam a parques (Awaji-Yumebutai, em Awaji, Hyogo), museus (Benesse House, Chichu Art Museum, Lee Ufan Museum e Ando Museum, todos localizados na ilha de Naoshima, Kagawa, e 21×21 Design Site, em Tóquio), o seu único templo budista e as igrejas já mencionadas, insiste-se na presença de escadas, plałaformas, mirantes, corredores, estruturas de atravessamento, sendo muitos deles encontrados em arquiteturas subterrâneas. A descida ao subsolo é pontuada por um percurso ritmado, gerando uma espécie de "zona limiar" (Walter Benjamin), quase ritual. Vale mencionar que em um projeto para a extensão das linhas de metrô da estação Shybuia, uma das mais movimentadas conexões de transportes em Tóquio, o subsolo é o palco, por assim dizer, para uma intervenção realizada pelo arquiteto. Como um evento no interior da estação, o observador é confrontado com uma forma ovóide em grande escala que difere da organização ortogonal dos demais elementos arquitetônicos. Como uma espécie de casulo, um objeto não identificado é posicionado na estação de modo a ser envolvido - e simultaneamente envolver - por muitos andares. Ao percorrer os andares da estação, o usuário é sempre surpreendido por protuberâncias, fragmentos dessa estrutura, de sua parte interior ou exterior. As noções de dentro e fora são articuladas para multiplicar as ambiguidades espaciais, e nunca para resolvê-las. 
Ambiguidades como essas são deliberadamente obtidas para acentuar a captura da percepção do observador e a instauração de uma temporalidade particular, como se pode apreender neste depoimento exposto junto à entrada do Ando Museum, em Naoshima:

"Respondi ao programa para projetar um museu para a minha própria arquitetura com a ideia de criar um edifício cujo foco seria a experiência espacial mesma (...) Sempre penso em como operar sobre um contexto existente usando a mínima expressão [the most minimum expression] para criar um espaço dotado de máxima profundidade [greatest depth] (...) Meu objetivo foi criar um espaço que tivesse um rico senso de profundidade apesar de sua pequena escala, no qual elementos opostos como passado e presente, madeira e concreto, luz e escuridão colidissem [clash] intensamente quando superpostos entre si".

Quanto à aplicação da noção de espaços de silêncio à pesquisa artística em curso, visando um efeito prático imediato, cabe destacar operações de vedação, ocultação, recobrimento e revestimento praticadas em obras da série Desenho:, ou noções de acúmulo, sobrevivência e sincretismo de formas e tipologias, com ênfase em elementos arquitetônicos da cidade de São Paulo, presentes nos tijolos de O Muro e Alvenaria, e nas janelas de Mostruário São Paulo e Caixilharia, mas de modo menos explícito nos conteúdos que alimentam Vazão e Sangue. Todas as obras procuram investigar modos de propor experiências de silêncio através de rupturas com a continuidade no fluxo temporal mais cotidiano. 


\section{ESCULTURA E CAMPO DA TRIDIMENSIONALIDADE}

Parece-me interessante reter a definição de tridimensional proposta por Donald Judd (JUDD, 1965): um tipo de linguagem distinta daquela do modernismo, na qual as diferenças de especificidade entre os meios tradicionais da pintura, da escultura, do desenho, e até mesmo da arquitetura eram abolidas em função de um conceito mais geral de arte. "Arte em geral", segundo observa Rosalind Krauss (2000). Não insistiria, contudo, na literalidade bastante própria ao Minimalismo contida no conceito de "objeto específico", também cunhado por Judd, operativo em seu momento histórico. Interessa-me, pois, pensar a arte não a partir de suas modalidades tradicionais, da especificidade de um meio material particular, mas sim a partir dos problemas suscitados pelas ideias e pelas experiências a serem propostas.

"A instalação fundamenta-se na reciprocidade entre o observador, - lugar e o tempo", disse Carlos Fajardo em uma de suas aulas, em 2014. Este "viés fenomenológico" (KRAUSS, 2000) orientou parte do desenvolvimento da escultura dos últimos sessenta anos e pode identificar-se com alguns dos trabalhos artísticos aqui desenvolvidos. O caráter fenomenológico da relação entre sujeito e objeto precede a mediação conceitual, idealista, contraria "a ideia de que o sentido de uma forma deve ser encontrado em seu caráter abstrato, ou em sua separabilidade, em seu isolamento com relação a uma situação concreta"28; contraria a ideia de que trata-se de "imaginar que nosso conhecimento do espaço transcende as especificidades de nossa perspectiva, que o espaço em si nos é apresentado como uma grade ideal"29.

\footnotetext{
${ }^{28}$ Rosalind Krauss, Caminhos da escultura moderna, São Paulo: Martins Fontes, 2001, p. 285.

$29 /$ dem, p. $285-286$.
} 
Em suma, admite uma contaminação entre aquilo que é diretamente apreendido pelo aparato sensorial, pelas relações emocionais e psicológicas (nas quais se inclui também a memória), e as conceituações que se seguem a isto. Admite, portanto, a presença de um observador "encarnado", nos diz Clair Bishop, cujos "sentidos tátil, olfativo e sonoro são tão destacados quanto o sentido da visão. Esta insistência na presença literal do observador foi defendida como principal característica da arte da instalação"30

Rosalind Krauss, em "Voyage on the North Sea: art in the age of the post-medium condition" (2000), procura realizar uma genealogia dos eventos que a partir do Minimalismo e da crítica à Arte Moderna - aos seus ideais de autonomia e de pureza da linguagem - foram importantes para a implosão das ideias de gênero, especificidade e categorias vinculadas à tradição. Eventos que incluem práticas radicais de crítica institucional, como a arte conceitual e a desmaterialização do objeto artístico, a performance, land art, site-specific, instalação. Segundo a autora, estabelece-se um novo paradigma para a produção artística fundamentado em noções de aparato formado por agregação, linguagens híbridas: a superação do meio unicamente identificado a si próprio, às suas características materiais ou operativas. Impõe-se um modo de operação fragmentado, cuja experiência se dá mediada por uma série de instrumentos técnicos distintos e simultâneos: "... o meio ou suporte do filme não é nem o celuloide, nem a câmera que capturou as imagens, nem o projetor que thes confere movimento, nem o raio de luz da projeção sobre a tela, nem mesmo a tela, mas tudo isto colocado junto, incluindo os espectadores situados entre a projeção e a fonte de luz" (KRAUSS, 2000, p.25). 
A autora demonstra que, a partir de meados dos anos 1950, as práticas artísticas responderão ao paradigma do "post-medium", da dissolução das linguagens tradicionais, das justaposições de meios heterogêneos, da condição intermídia, aberta às hibridizações, na qual o suporte de uma obra já não se vê identificado unicamente consigo próprio. Esse novo paradigma gerará a noção de instalação, modalidade que a autora percebe com desconfiança. ${ }^{31}$

Ela duvida da capacidade permanente de resistência do objeto artístico às assimilações e apropriações levadas a cabo pelos poderes hegemônicos, seja do capitalismo, dos discursos institucionais, críticos, mercadológicos, fenômeno que se manifesta concretamente nas formalizações e estilizações de práticas originalmente experimentais, e que é visto em feiras e bienais pelo mundo. A autora explicita que a condição "post-medium" talvez ofereça uma forma de resistência crítica aos ditames mercadológicos e às formas carentes de invenção. Deseja-se que esta reflexão crítica sirva, portanto, de escopo conceitual para as obras e projetos aqui desenvolvidos.
${ }^{31}$ Esta noção foi construída a partir dos anos 1960, como demonstra Clair Bishop, separando-se de um emprego corrente que definia a disposição dos objetos artísticos em um determinado espaço ("... há uma linha tênue entre a arte instalada e arte da instalação (...) Durante esta década, a palavra 'instalação' foi usada por revistas de arte para descrever o modo como uma exposição era disposta [arranged]" Clair Bishop, op. cit., p. 6, tradução nossa). Havia, contudo, práticas precedentes que já incorporavam nas obras o espaço ao redor como valor formal, como as de Vladimir Tatlin (Relevo de canto, 1915), El Lissitzky (Proun Room, 1923), Marcel Duchamp (sobretudo a Exposição Internacional Surrealista de 1938, realizada em Paris) e Constantin Brancusi (esculturas cuja superfície espelhada se fundem com o espaço ao redor da peça e tornam tênues os limites entre objeto e espaço, como em Musa adormecida, 1910), para citar algumas das figuras mais icônicas. 


\section{OBRAS REALIZADAS}

(2014 - 2016) 


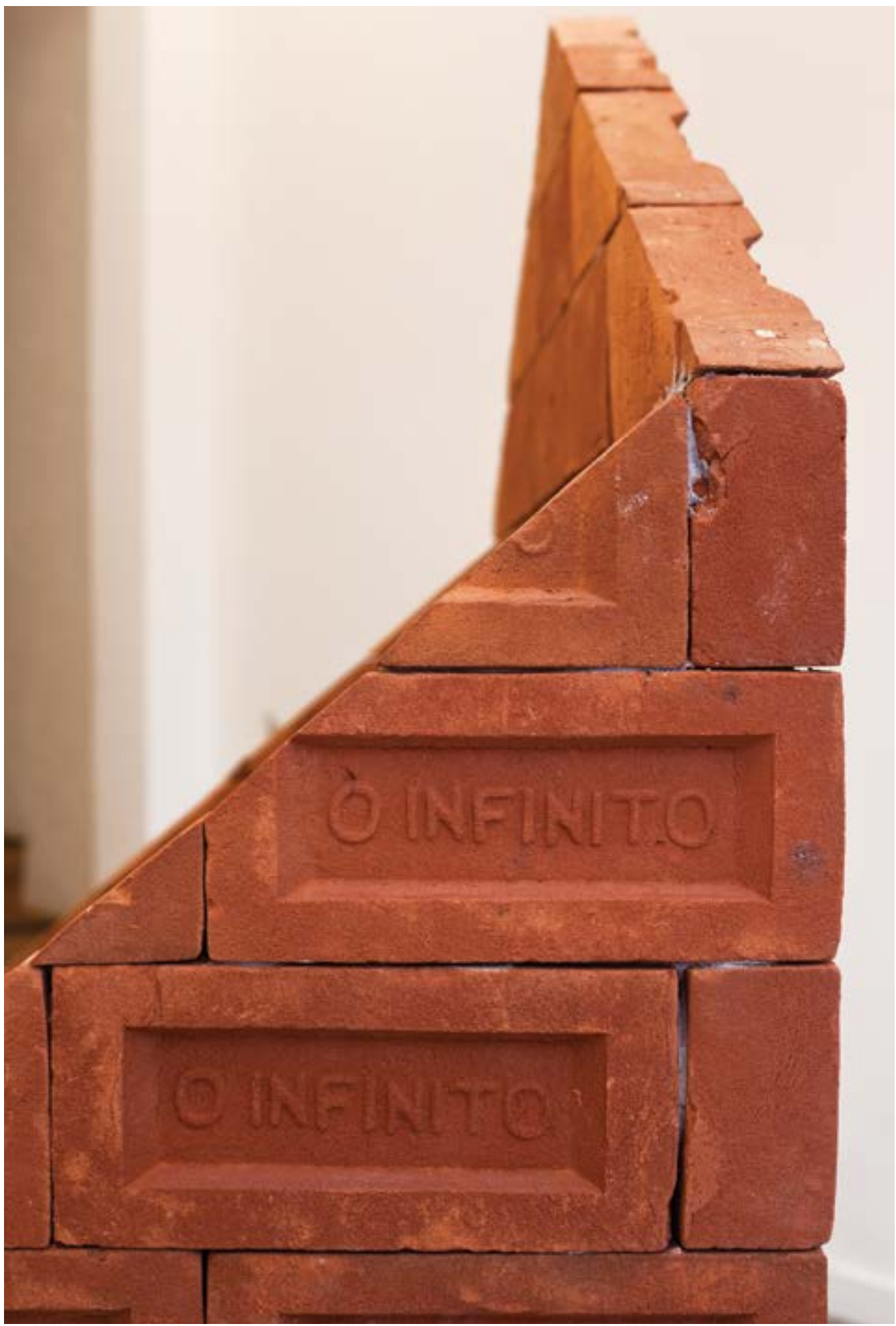




\author{
ALVENARIA 2015 \\ Tijolo de barro cozido personalizado, massa de assentamento \\ $119 \times 125 \times 134,5 \mathrm{~cm}$ \\ Reminiscências (2015) \\ Galeria Tato, São Paulo \\ Exposição individual
}

A forma da estrutura reproduz o desenho da fachada de uma arquitetura observada na cidade de São Paulo. Pode ou não apresentar variação na escala para adequar-se ao espaço de exibição. $O$ título "Alvenaria" remete diretamente à técnica construtiva para associar-se, conceitualmente, à tradição bastante difundida da alvenaria de tijolos, característica de um momento específico da história da arquitetura e do urbanismo em São Paulo, em que se configura uma fisionomia da cidade ainda visível contemporaneamente. Utiliza-se um tijolo de barro produzido por técnica tradicional (não industrial) em olaria, acreditando que pode conectar-se a este repertório familiar ao habitante da cidade.

Porém, ocorre uma diferenciação no tijolo usado na obra: apresenta em sua superfície, estampados, os termos "O INFINITO", "NUNCA", "AMANHÃ", "ILUSÃO" e "HORIZONTE", para impor temporalidades e espacialidades contraditórias às qualidades do tijolo e também de uma parede erguida com tijolos. Se o tijolo é uma massa compacta, uma pedra artificial feita de argila vermelha cozida, e se um muro consiste no empilhamento dessas unidades compactas para gerar um todo opaco, uma vedação, pretende-se que as palavras possam sugerir rupturas no discurso material desses objetos. 

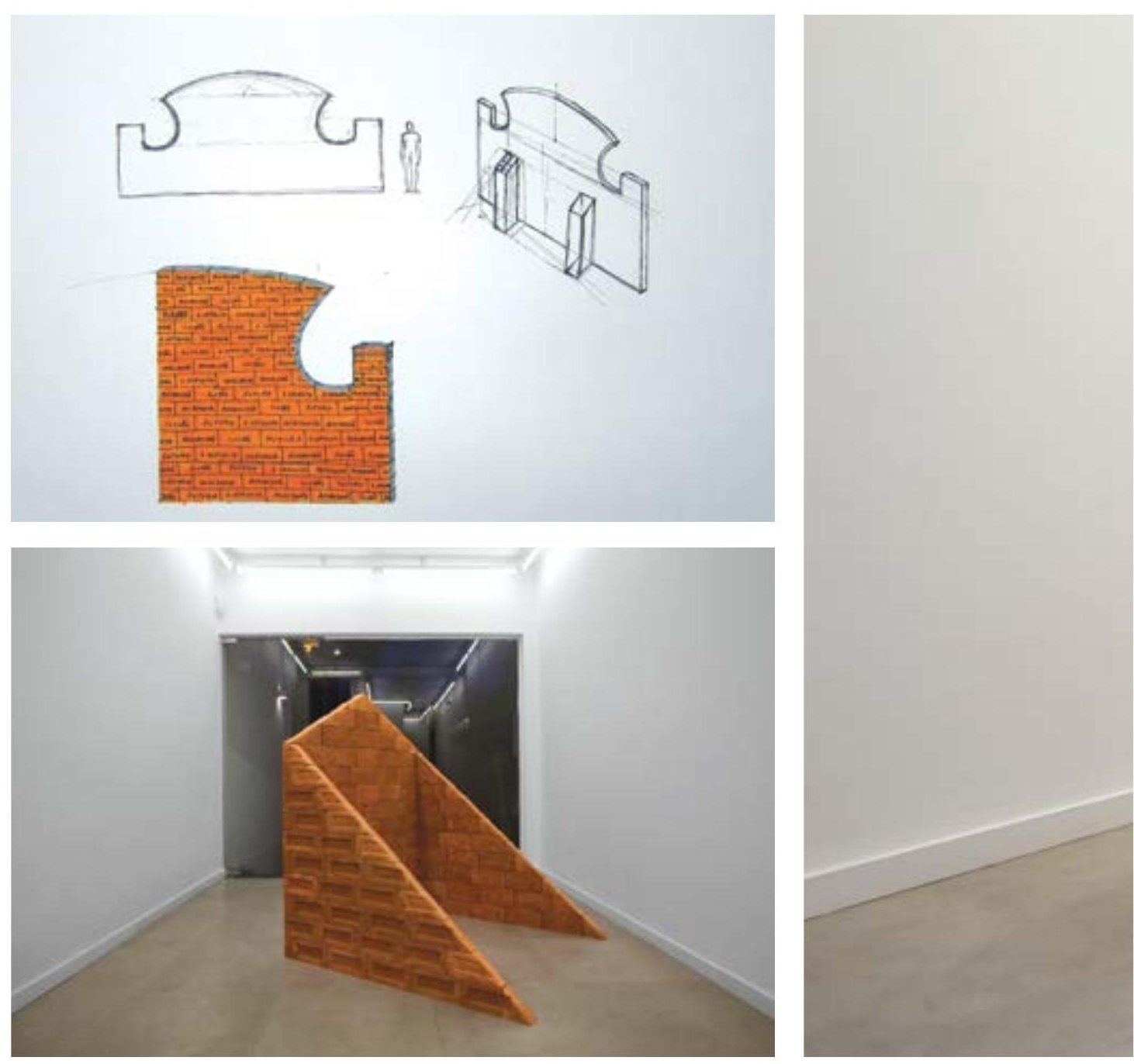


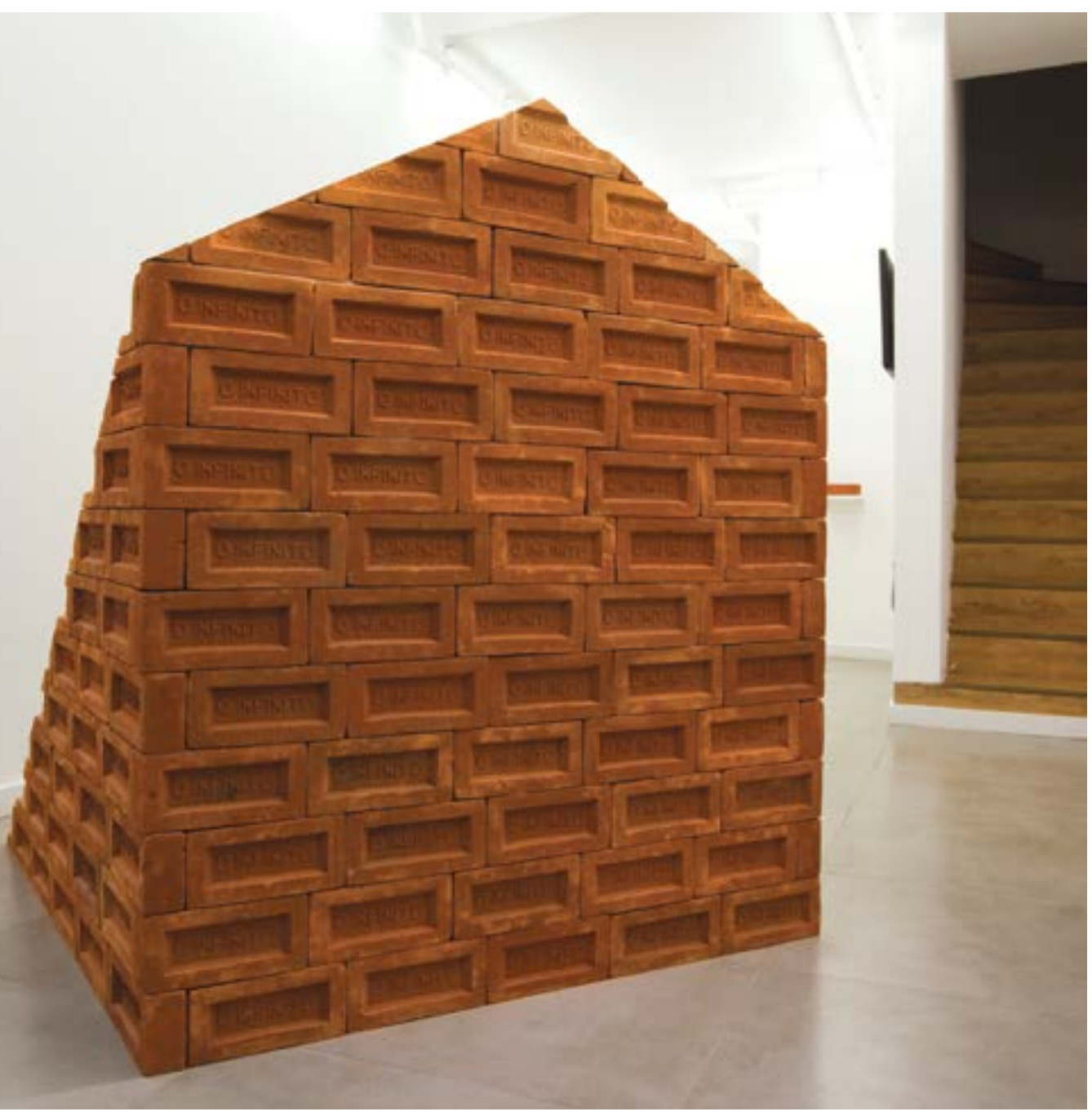



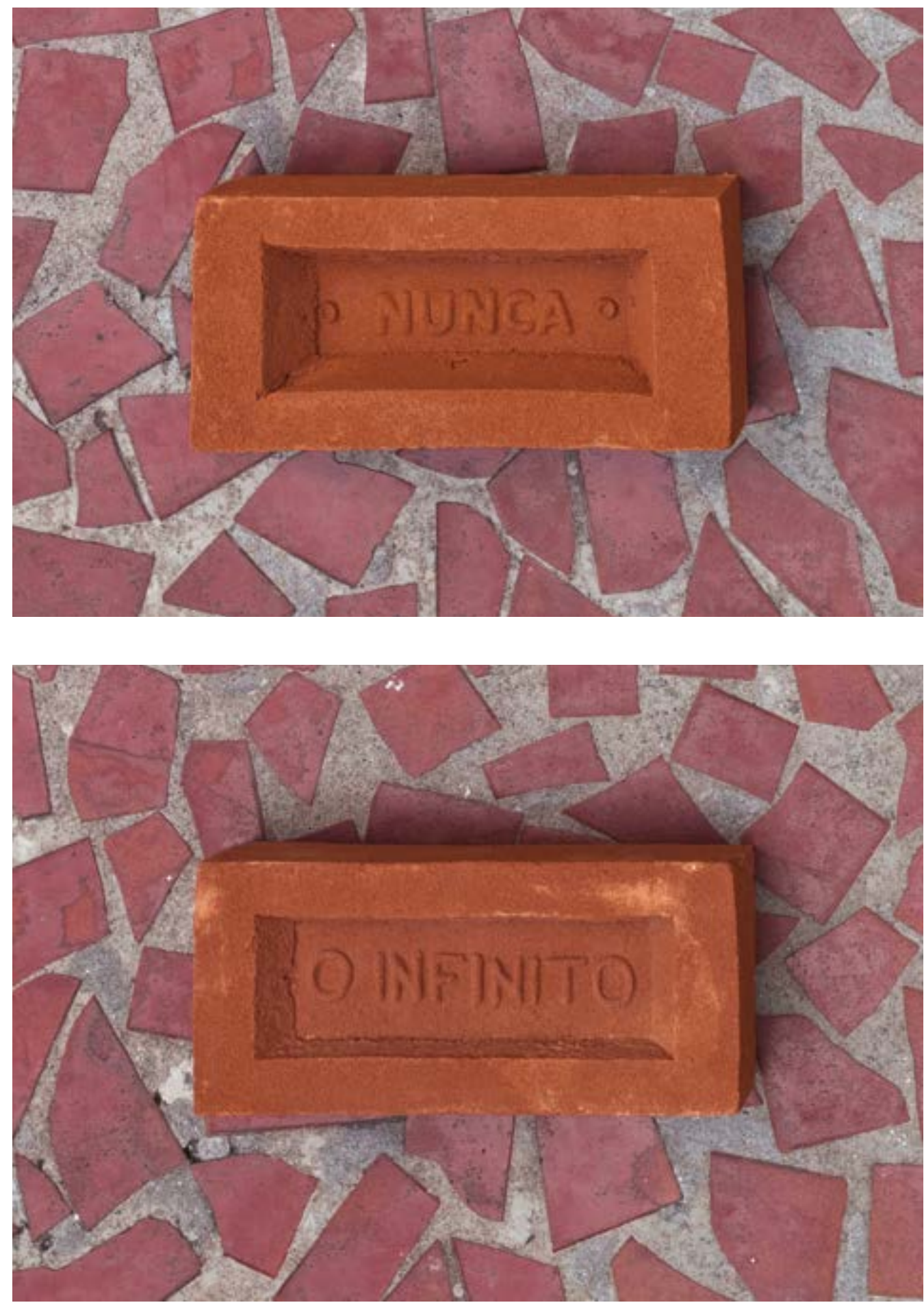

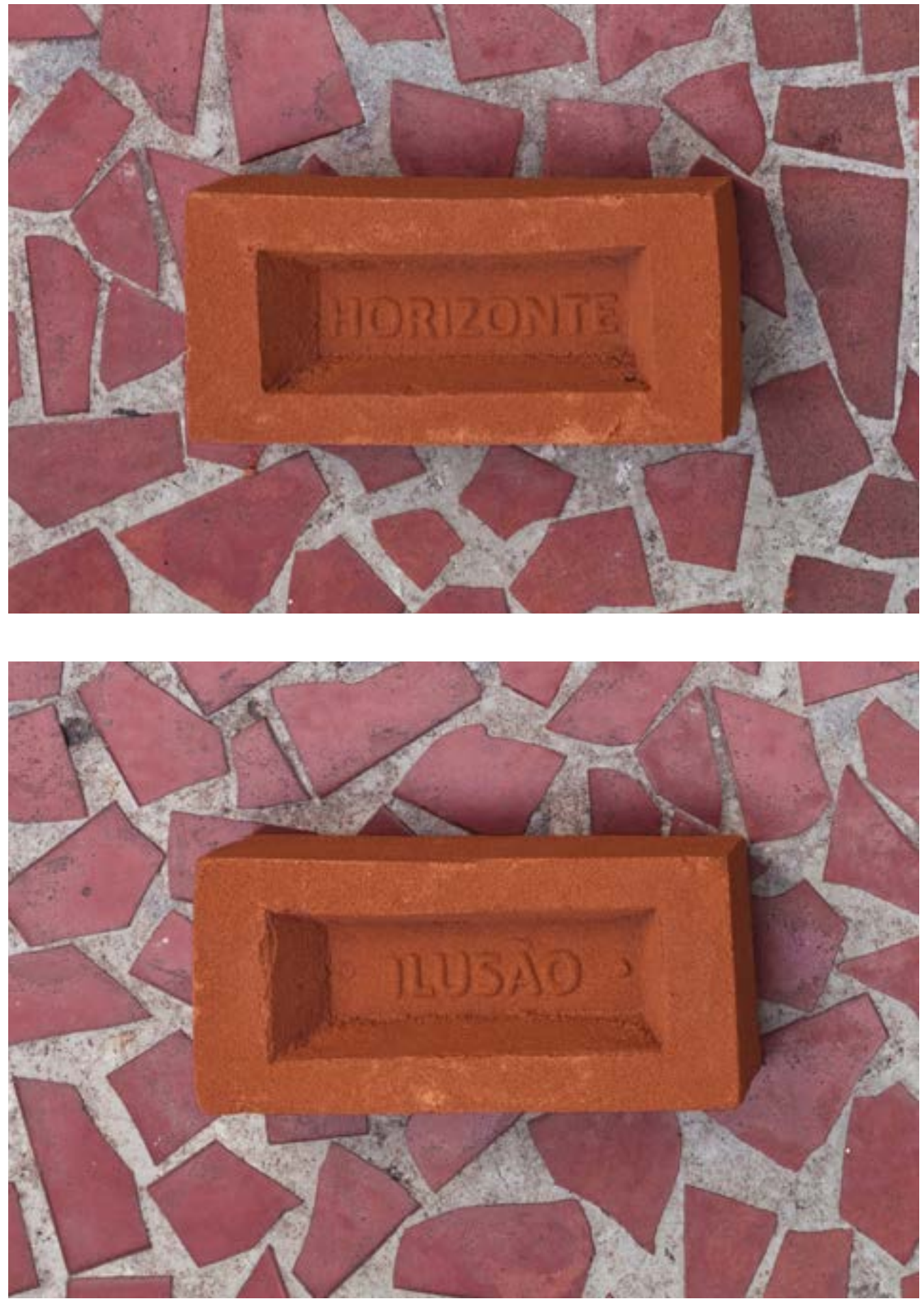


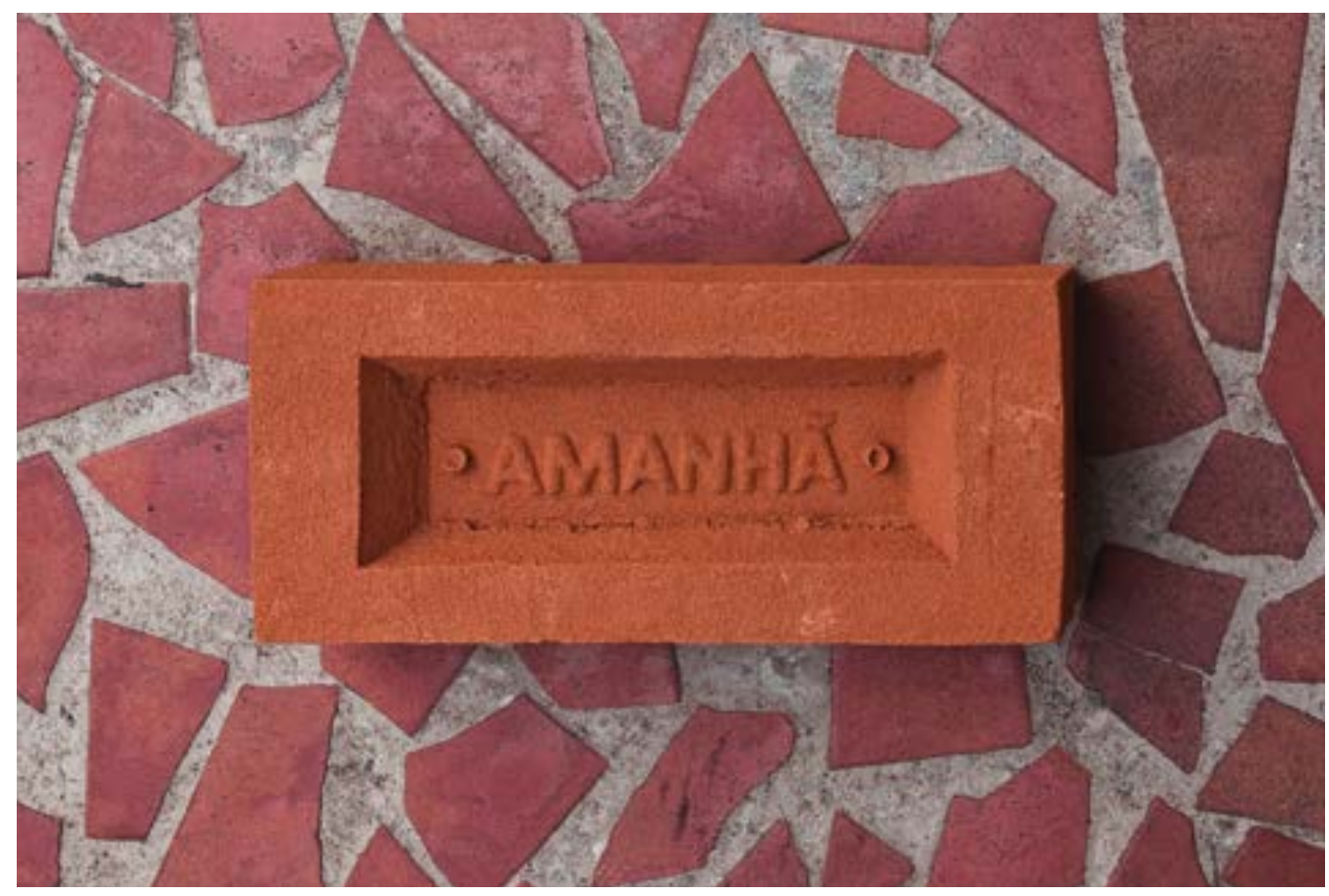


CAIXILHARIA $2013-2015$

Desenho digital, impressão sobre MDF

$60 \times 42 \times 0,9 \mathrm{~cm}$ (cada)

Reminiscências (2015)

Galeria Tato, São Paulo

Exposição individual

Em Caixilharia buscou-se construir uma espécie de coleção arqueológica de modelos de janelas encontrados em arquiteturas da cidade de São Paulo, tanto a partir da observação direta, quanto da apropriação de modelos encontrados em pesquisas iconográfica e bibliográfica.

Serviram de referência diversas fontes dos séculos XIX e XX, como, por exemplo, fotografias de Militão Augusto de Azevedo, desenhos de Jean-Baptiste Debret, e projetos - inclusive alguns não realizados - do arquiteto Victor Dubugras. Deseja-se ainda incluir, em futuros desenvolvimentos da obra, modelos ecléticos projetados pelo escritório do arquiteto Ramos de Azevedo, ou pelos precursores do modernismo Flávio de Carvalho, Rino Levi e Gregori Warchavchik, além de registros da arquitetura colonial feitos pelo desenhista José Wasth Rodrigues, autores que contribuíram para a definição de tipologias amplamente difundidas, apropriadas pela arquitetura popular, com maior ou menor grau de fidelidade às fontes autorais.

Todos os modelos apresentam dispositivos capazes de gerar pequenas frestas. Pretende-se sugerir a "sobrevivência" (Didi-Huberman) destes dispositivos durante o desenvolvimento da arquitetura em São Paulo. 

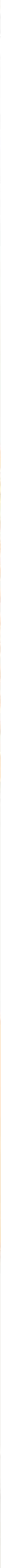


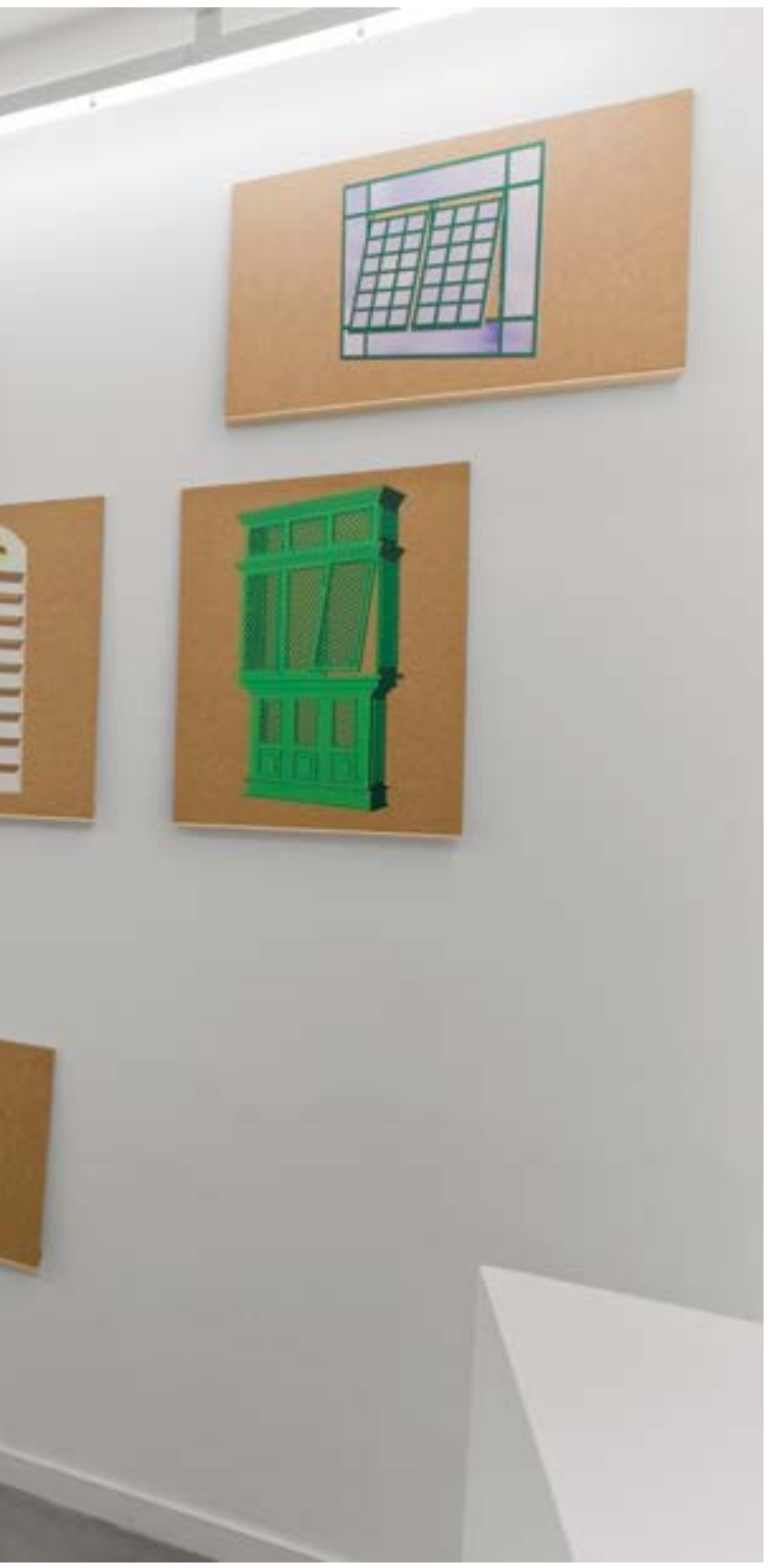

O procedimento formal consistiu em desenhar, com o auxílio de ferramentas digitais de modelagem 3D, cada modelo escolhido para assemelhar-se ao desenho contemporâneo de projeto arquitetônico. Esta imagem que pressupõe um espaço tridimensional de representação, ilusionista, foi impressa em MDF cru, para contrastar com uma superfície "dura" que repele o olhar, evita abrir-se como janela, como superfície projetiva. 

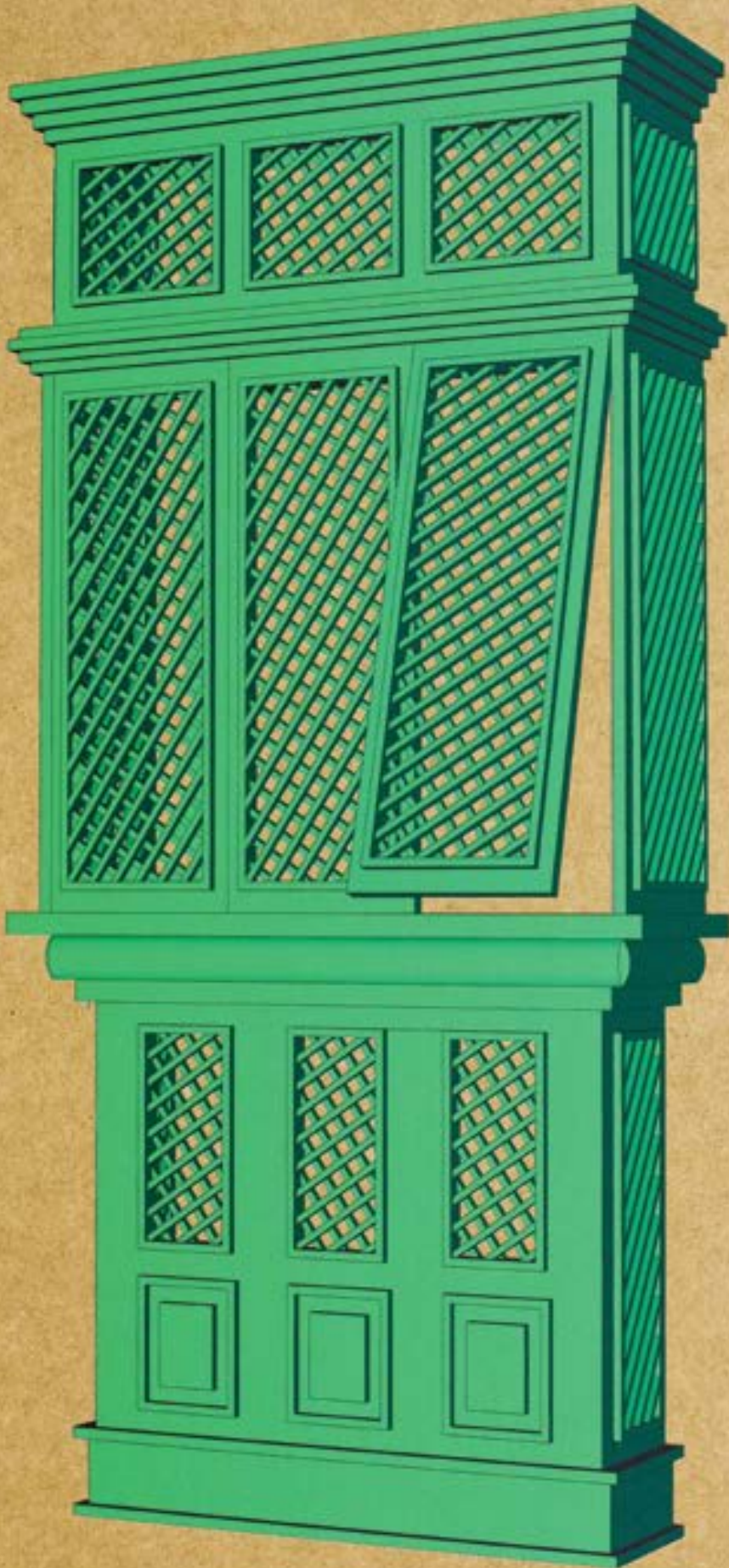


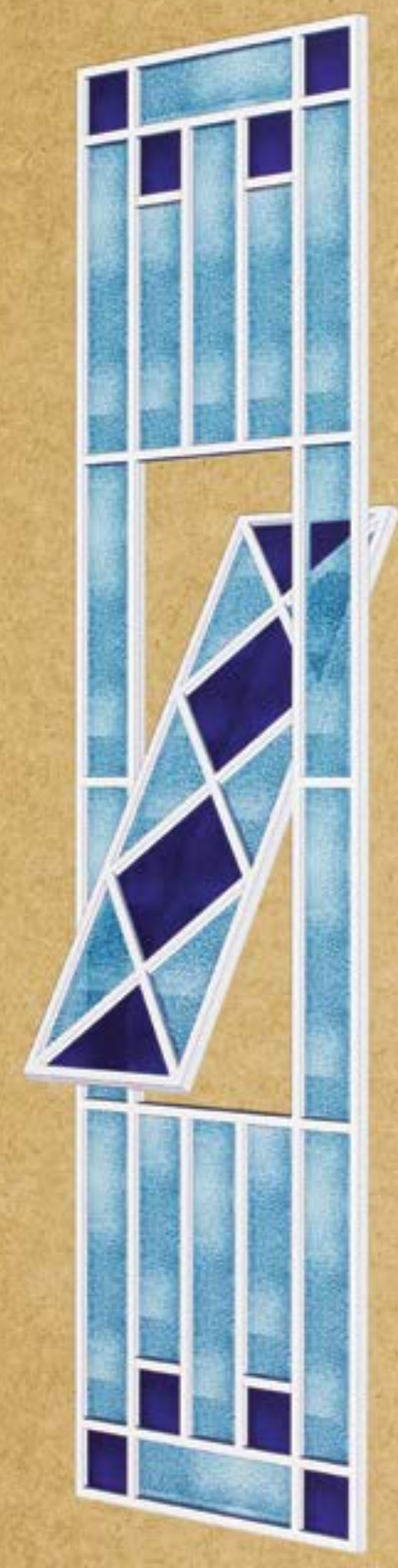




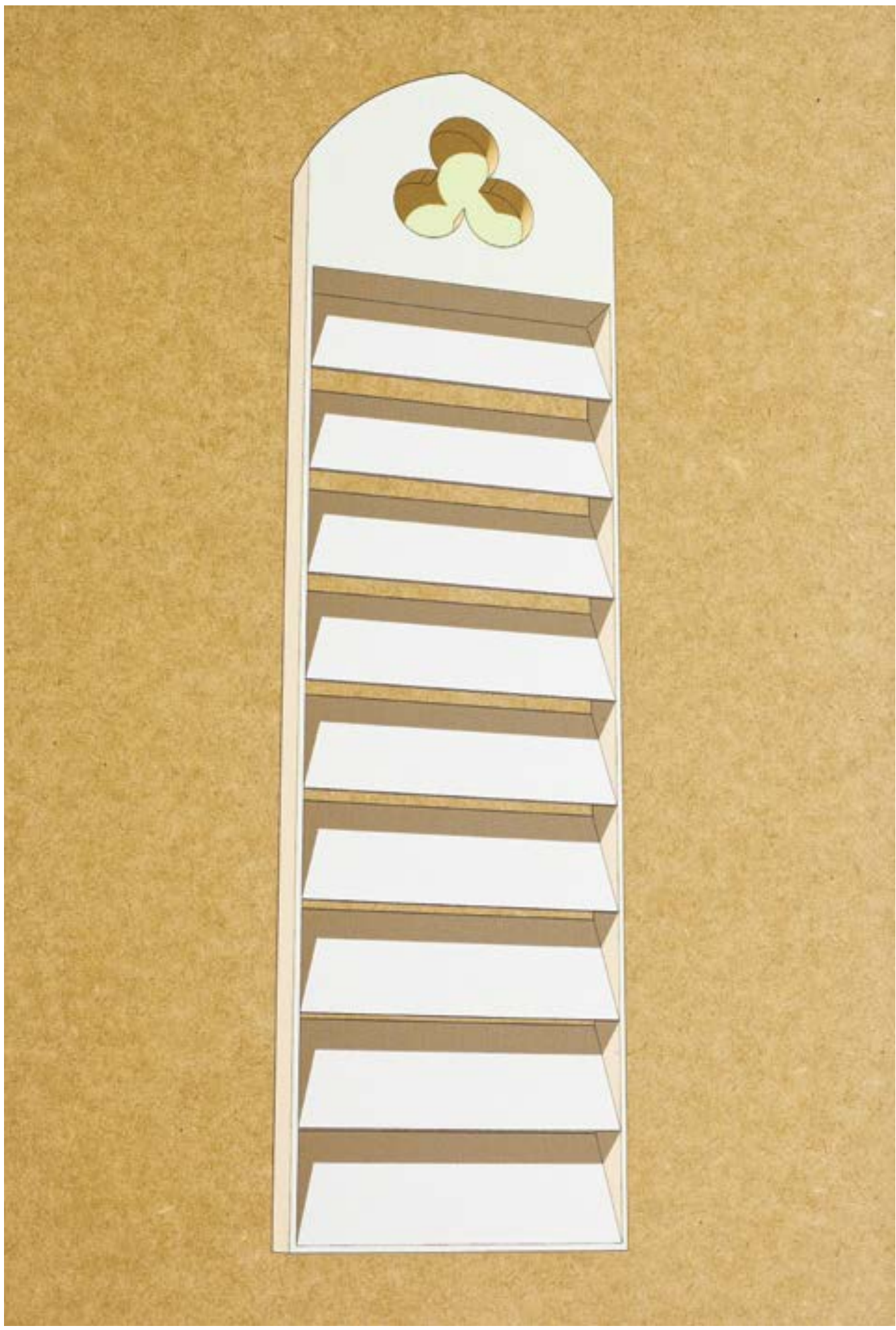



SÉRIE DESENHO: (2011 - 2015)

As instalações da série Desenho: procuram investigar mais diretamente aquilo que procurou-se definir como "espaços de silêncio", experiências análogas àquelas vividas em ruínas arquitetônicas e em espaços deliberadamente construídos nos quais apresenta-se uma descontinuidade espaço-temporal. As ruínas "contrariam o devir abstrato do tempo" (Olgária Matos) e "agregam um conjunto de paradoxos temporais e históricos" (Brian Dillon). Alguns espaços construídos tem a capacidade de ser inertes: o movimento é suspenso e a temporalidade reduzida ao fluir mais imperceptível. São referência os espaços projetados pelos arquitetos Luís Barragán e Tadao Ando.

Por meio da vedação de portas e janelas - intervenções em contextos arquitetônicos pré-existentes - as instalações buscam desfuncionalizar, fragmentar, interromper e suspender a continuidade da arquitetura, promover pausa. A vedação é feita com a colagem de tipos comuns de papéis, como o manilha e o kraft não resinado, ou com outros tipos de recobrimento. Pretende-se que a arquitetura passe a expressar-se por sua superfície tornada homogênea, cujos relevos pareçam esculpidos, como se houvesse regredido a um estado projetivo, uma maquete ou modelo tridimensional.

Desenho: FIG.1 (Vidraça), 2015

Papel semi-kraft colado diretamente sobre arquitetura, vedando uma vidraça

$5,2 \mathrm{~m}^{2}$ (aproximadamente)

Reminiscências (2015)

Exposição individual Galeria Tato, São Paulo 


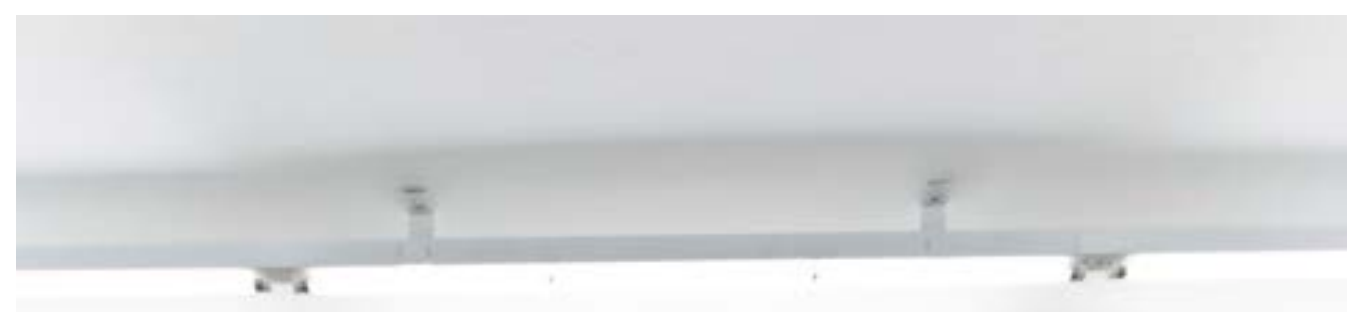

\section{FIG. 1}


Desenho: FIG.1 (Vidraça), 2015

Papel semi-kraft colado diretamente sobre arquitetura, vedando uma vidraça $5,2 \mathrm{~m}^{2}$ (aproximadamente)

Reminiscências (2015)

Exposição individual Galeria Tato, São Paulo 


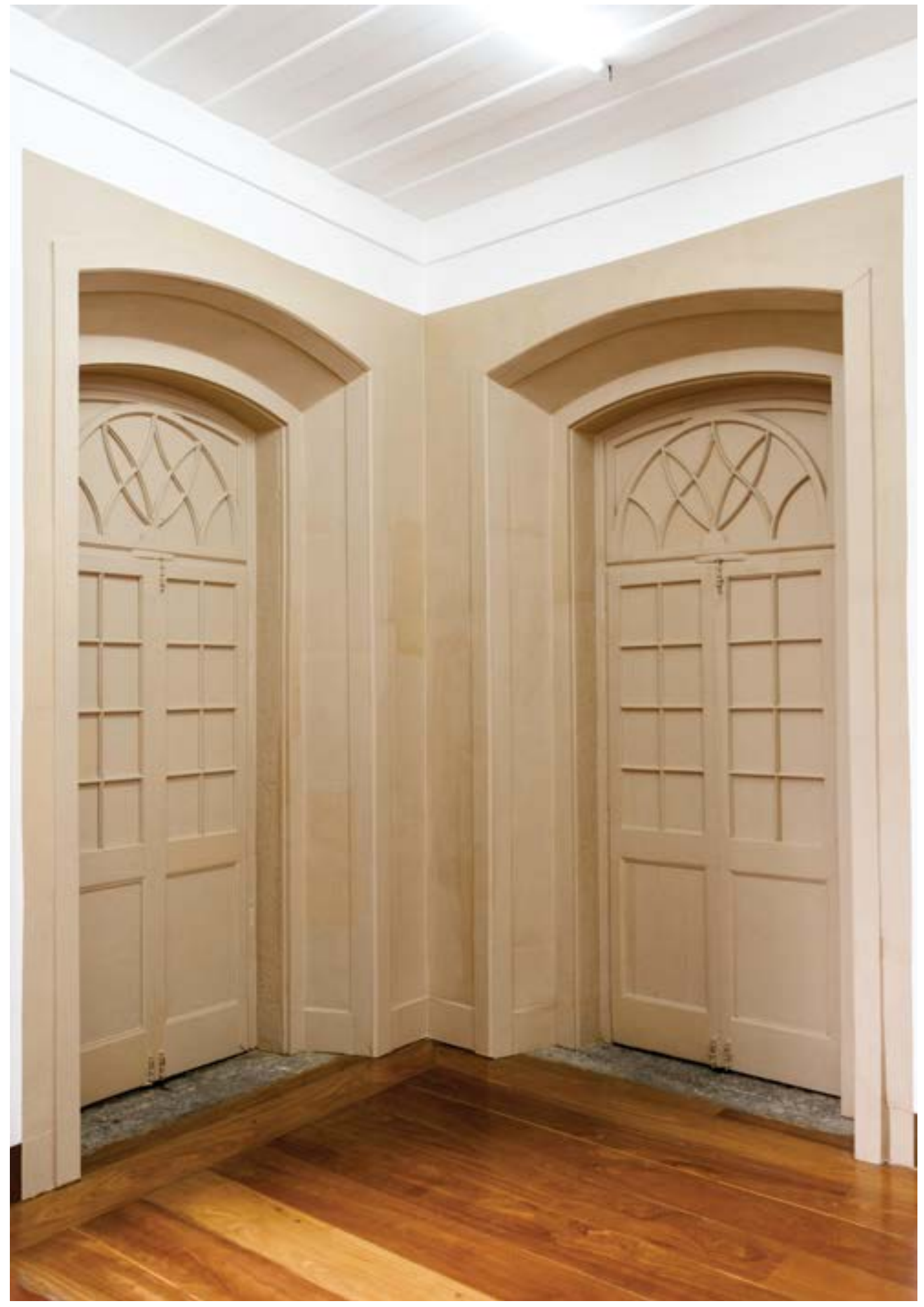




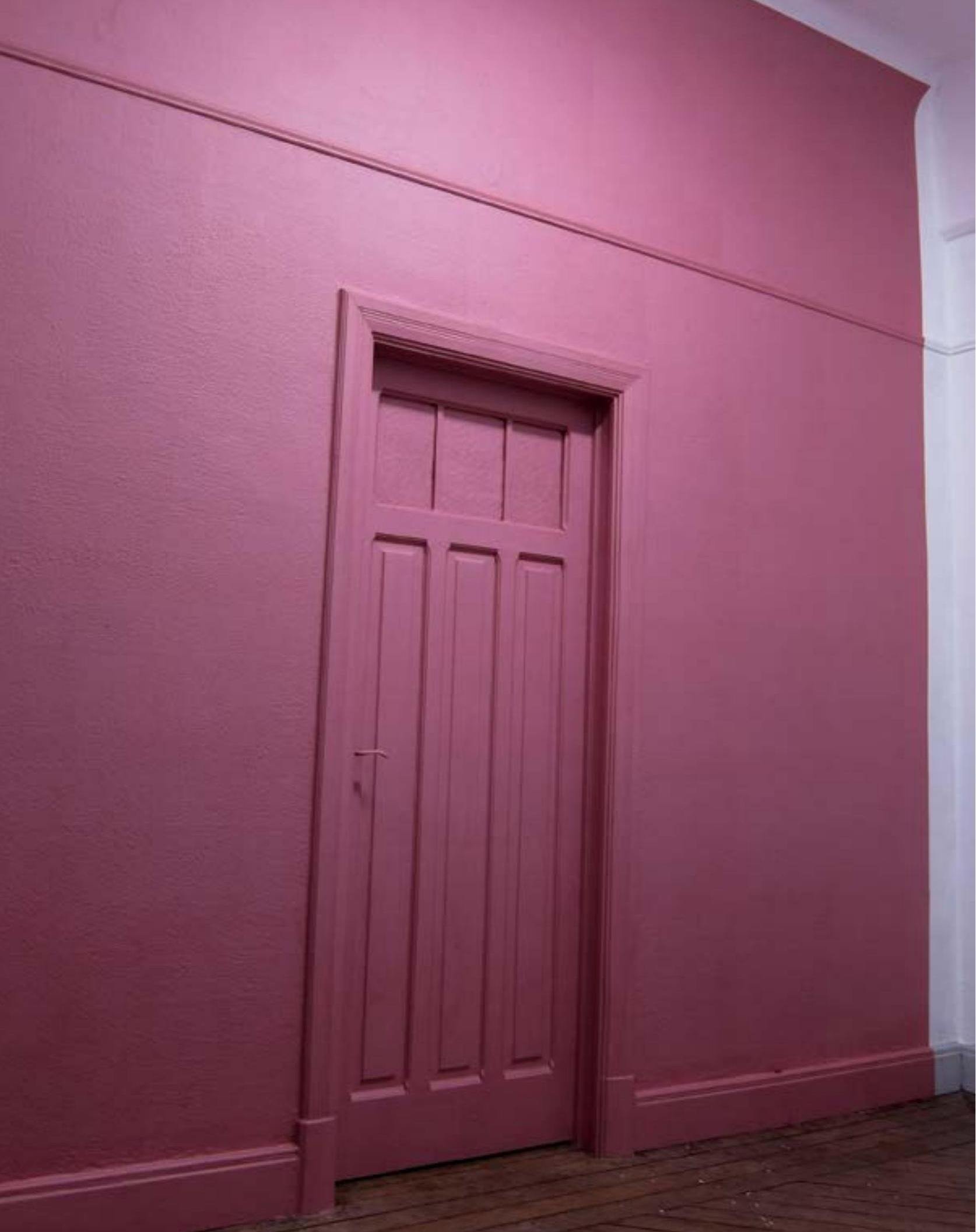


Desenho: parede e porta, 2011

Papel manilha rosa colado diretamente sobre arquitetura, vedando uma porta $13 \mathrm{~m}^{2}$

Red Bull House of Art, São Paulo 
 \\ Sig. \\ 3 श्रा} $32 \times-2$

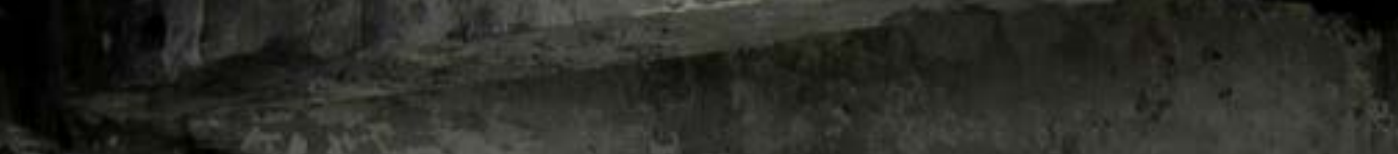

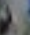

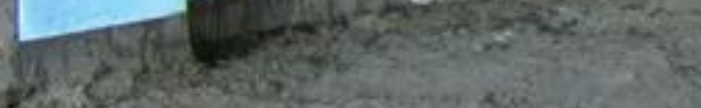

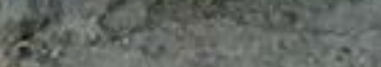

(6)

-

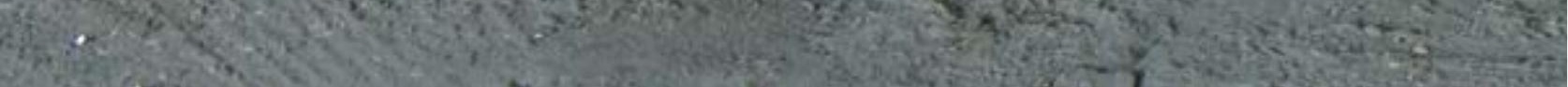




\section{MOSTRUÁRIO SÃO PAULO 2013 - 2016}

Blocos de concreto, hastes de alumínio, maquetes de papel recortadas

a laser e montadas manualmente. Dimensões variáveis.

A realização das maquetes contou com o apoio técnico do LAME

(Laboratório de Modelos e Ensaios) da Faculdade de Arquitetura e Urbanismo da Universidade de São Paulo.

Exposições: Reminiscências (2015), Galeria Tato, São Paulo - Exposição individual.

Metáforas construidas (2015), La Cometa Galería, Bogotá, Colômbia Exposição coletiva.

A apologia ao uso de dispositivos basculantes, projetantes e pivotantes parece ganhar força com o modernismo em arquitetura. Le Corbusier roga o uso das basculantes em textos dos anos 1920 reunidos no volume Por uma arquitetura (1923, publicado no Brasil pela Perspectiva em 1973). Se para o arquiteto a casa é uma "máquina de morar", as basculantes seriam a parte funcional da máquina que garante modular a ventilação. No Brasil, como pretexto, falou-se também em fatores mesológicos (notadamente higienistas), na adequação das janelas à insolação e às troca de ar e de temperatura em ambientes tropicais, além do ganho com a produção industrial em série (COUTINHO, 1930). É notável a presença desses dispositivos em projetos arquitetônicos modernos pioneiros de Victor Dubugras (a estação de Mairinque, de 1906, é o caso mais emblemático), Gregori Warchavchik, Flávio de Carvalho e Rino Levi. Contudo, os dispositivos já são conhecidos, no contexto paulistano, desde os tempos coloniais.

Rótulas, muxarabis e gelosias foram comuns em muitas cidades do Brasil colônia, o que pode ser atestado por vasta iconografia de imagens de arquiteturas produzidas no período. Vale citar os registros de Jean Baptiste Debret, Henry Chamberlain, Thomas Ender, Charles Landseer, assim como as fotografias de Militão Augusto de Azevedo. 
A partir do contexto da arquitetura neocolonial (décadas de 1910 e 1920), foram realizados estudos específicos por arquitetos e historiadores como Lúcio Costa, Ricardo Severo e José Wasth Rodrigues. Este último nos legou o seguinte depoimento sobre o muxarabi: "... deve ter sido muito comum em São Paulo, devendo mesmo ser considerado elemento característico desta cidade" (RODRIGUES, 195, p.7). Pude observar exemplares de gelosias remanescentes em Ouro Preto, Mariana e Parati. Conforme nos relatam os arquitetos e historiadores mencionados, alguns poucos exemplares restaram em Diamantina, Olinda e Santana do Parnaíba. Desapareceram por proibições oficiais ao longo do século XIX.

Essas diversas formas históricas de janelas - coloniais e contemporâneas - oferecem modelos de mediação entre o interior do espaço arquitetônico e o exterior, a cidade. Encontram, a meu ver, um fundamento comum, um mesmo tipo de dispositivo cuja particularidade é gerar frestas, espaços exíguos de comunicação entre dois ambientes. São sobrepostos ainda, outros recursos para conferir maior ou menor transparência: as treliças de madeira que foram utilizadas nas gelosias encontram o seu correspondente contemporâneo na imensa gama de vidros texturizados, cujo efeito análogo é bloquear parcialmente a visibilidade, mas permitir a entrada de luz.

Pretende-se que a obra artística articule noções de sobreposição temporal, sobrevivências de repertórios anacrônicos, obsoletos, que são apropriados pelo uso popular, consistindo em uma espécie de "cemitério" de janelas, como uma coleção arqueológica de tipologias encontradas em fachadas de arquiteturas da cidade de São Paulo. 


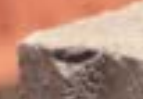




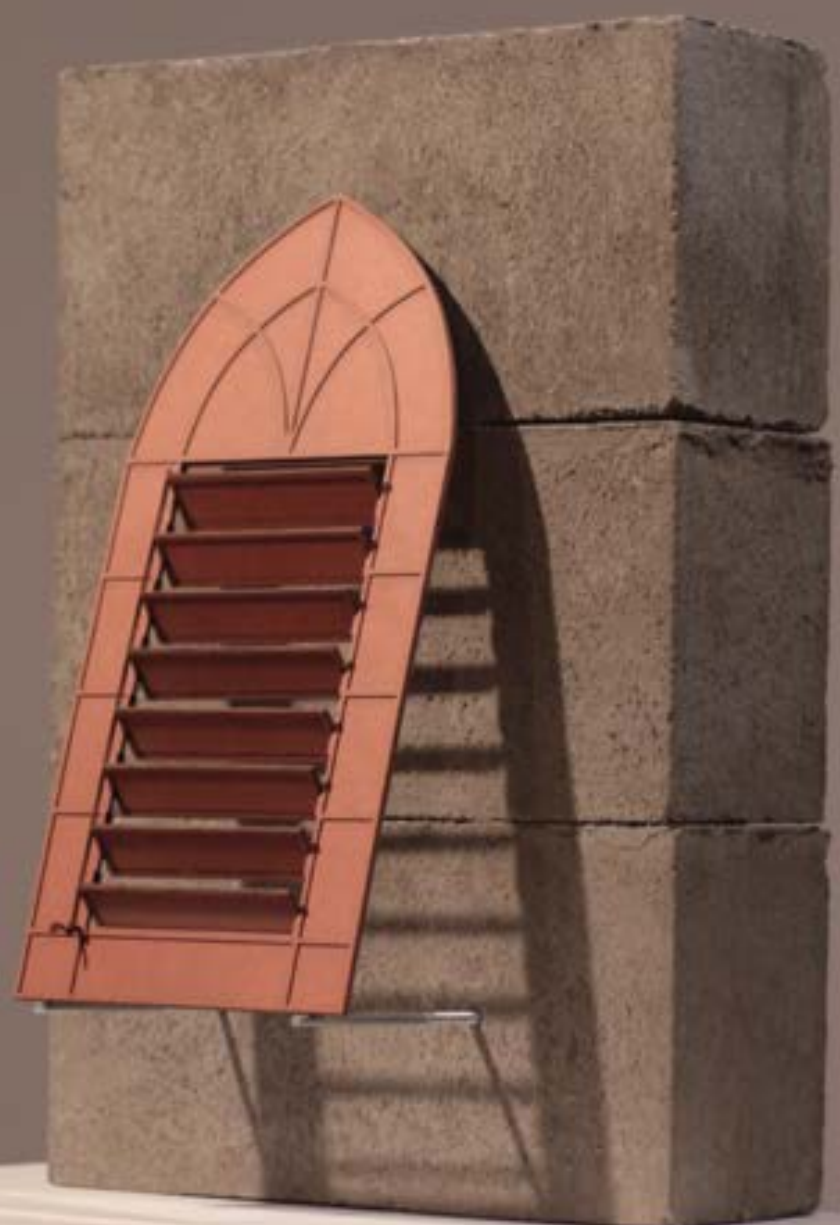




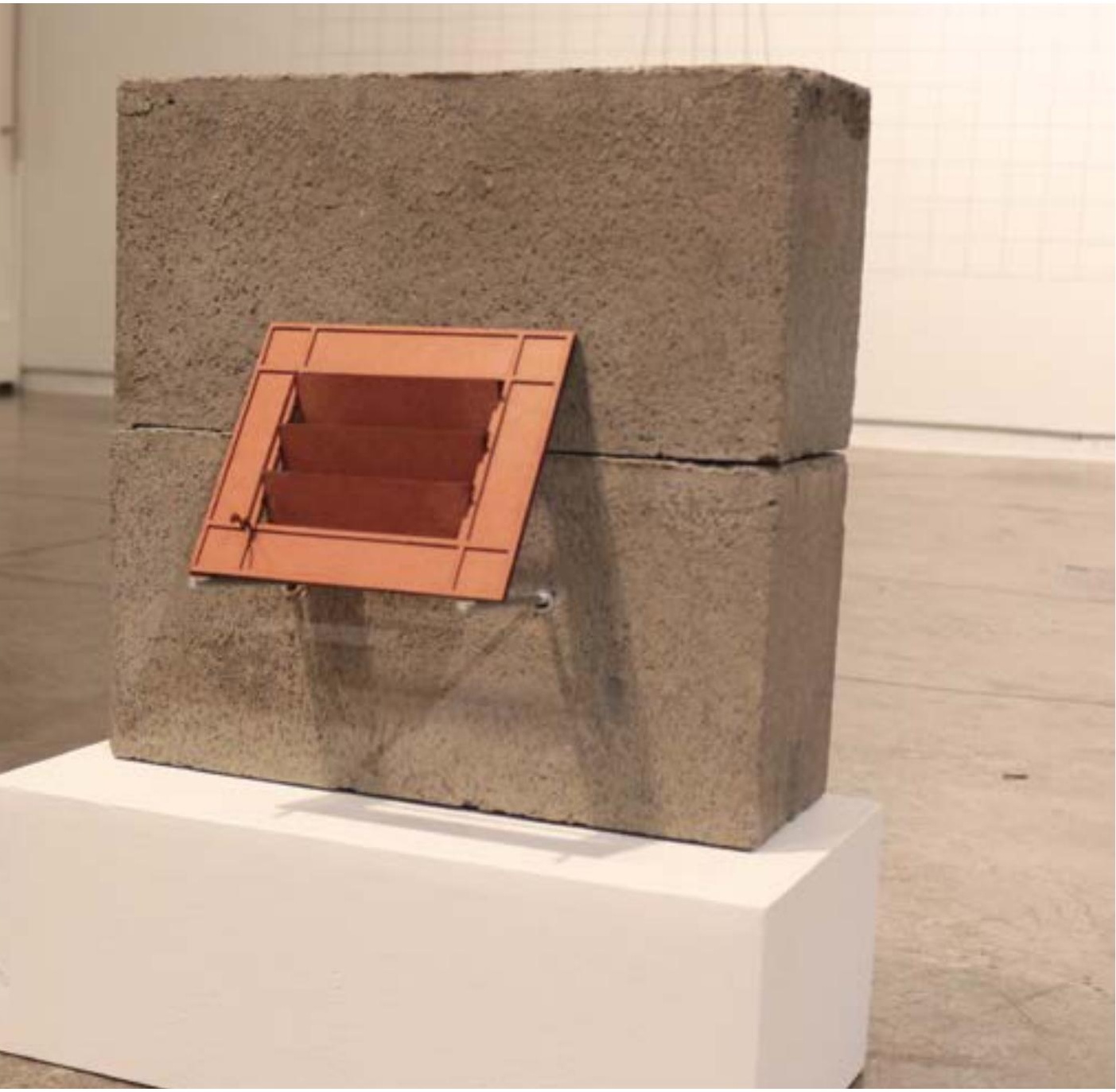




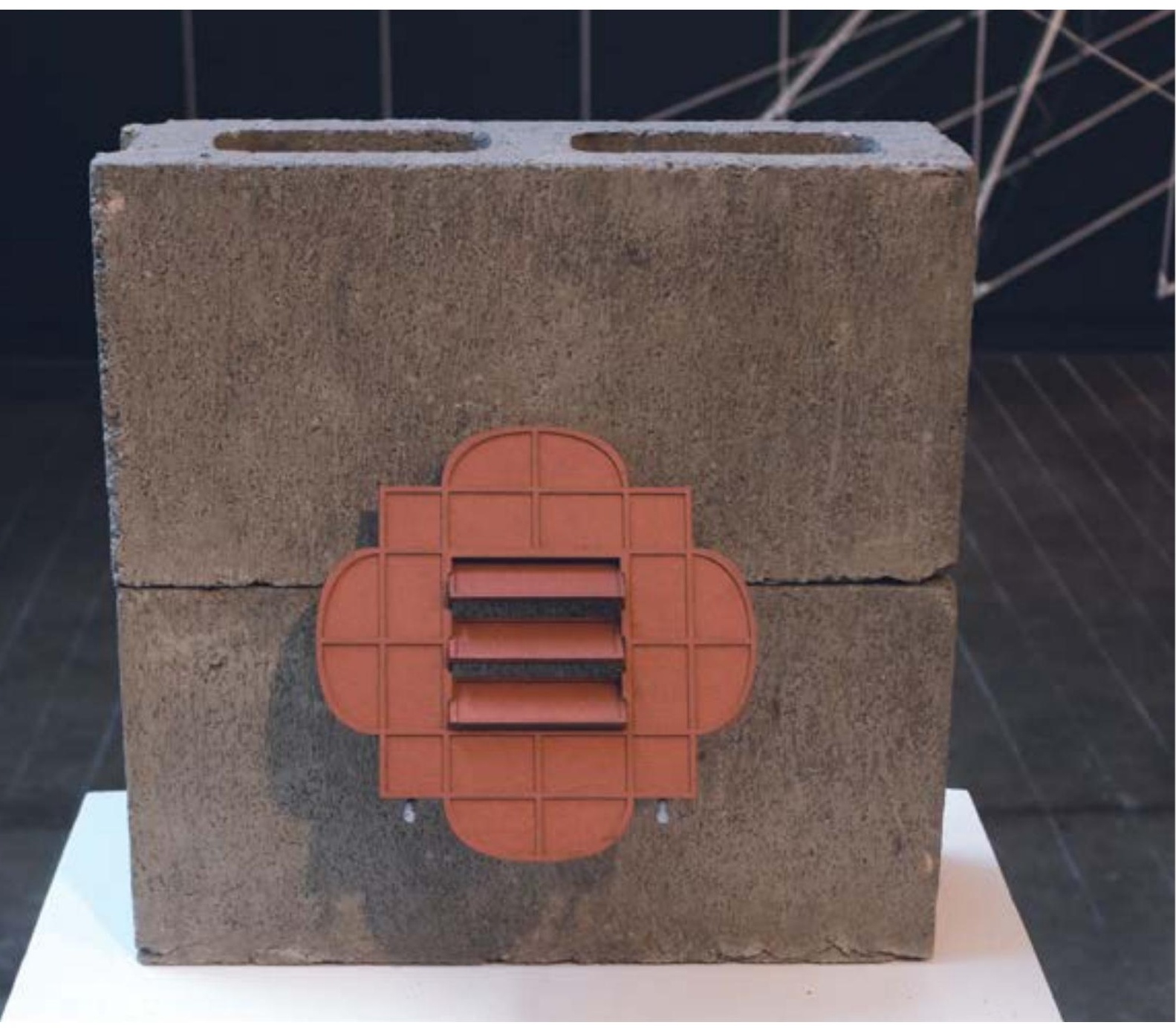




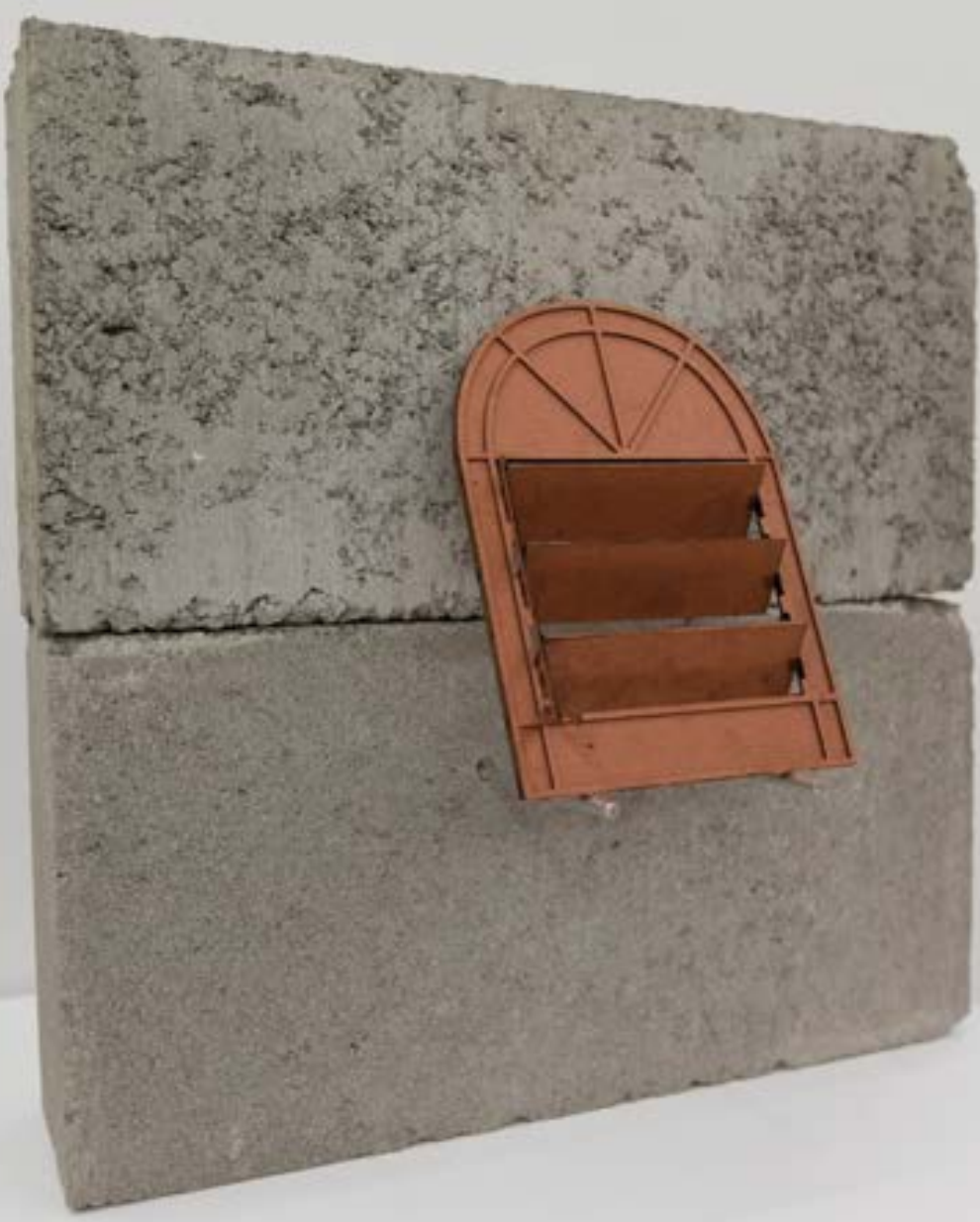




\section{O MURO 2014}

Parede coberta por tijolos de barro cozido

$52,5 \mathrm{~m}^{2}$

Tijolos produzidos artesanalmente na Olaria Spina, Cabreúva, São Paulo Sesc Ipiranga, São Paulo - Exposição individual

Não é por acaso que o tijolo de barro cozido é tão familiar ao paulistano. A sua generalização como principal material construtivo ocorreu em São Paulo há cerca de 150 anos, modificando radicalmente, em poucas décadas, a fisionomia da cidade. A alvenaria de tijolos substituiu os modos construtivos coloniais ligados à taipa - e ao trabalho escravo - e atendeu adequadamente à necessidade de expansão acelerada da malha urbana na reconfiguração do centro e na formação dos novos bairros periféricos, incluindo o Ipiranga, ao longo da linha ferroviária recém-implantada. A difusão do tijolo liga-se intimamente à influência do imigrante estrangeiro, ao seu conhecimento técnico e repertório formal. Foi extensamente aplicado a todos os tipos de edificações e criou tipologias com as quais convivemos ainda hoje, diariamente.

A instalação $O$ Muro foi projetada para evocar esta memória da arquitetura da cidade. Mas esta memória importa somente se é capaz de evocar também as pequenas histórias pessoais, afetivas, de seus habitantes. O tijolo utilizado na instalação recebeu ainda uma intervenção para dotar uma parede de um conteúdo enigmático: sobre uma das faces do tijolo foi estampado o texto "o infinito", para provocar ideias sobre a perda de limites. Se o objetivo de uma parede é vedar, impor limites a um espaço, "o infinito" procura sugerir uma situação oposta. Procura ser uma mensagem sutil, camuflada, mas repetida exaustivamente como uma espécie de "sussurro", de imaginação dessa parede. 


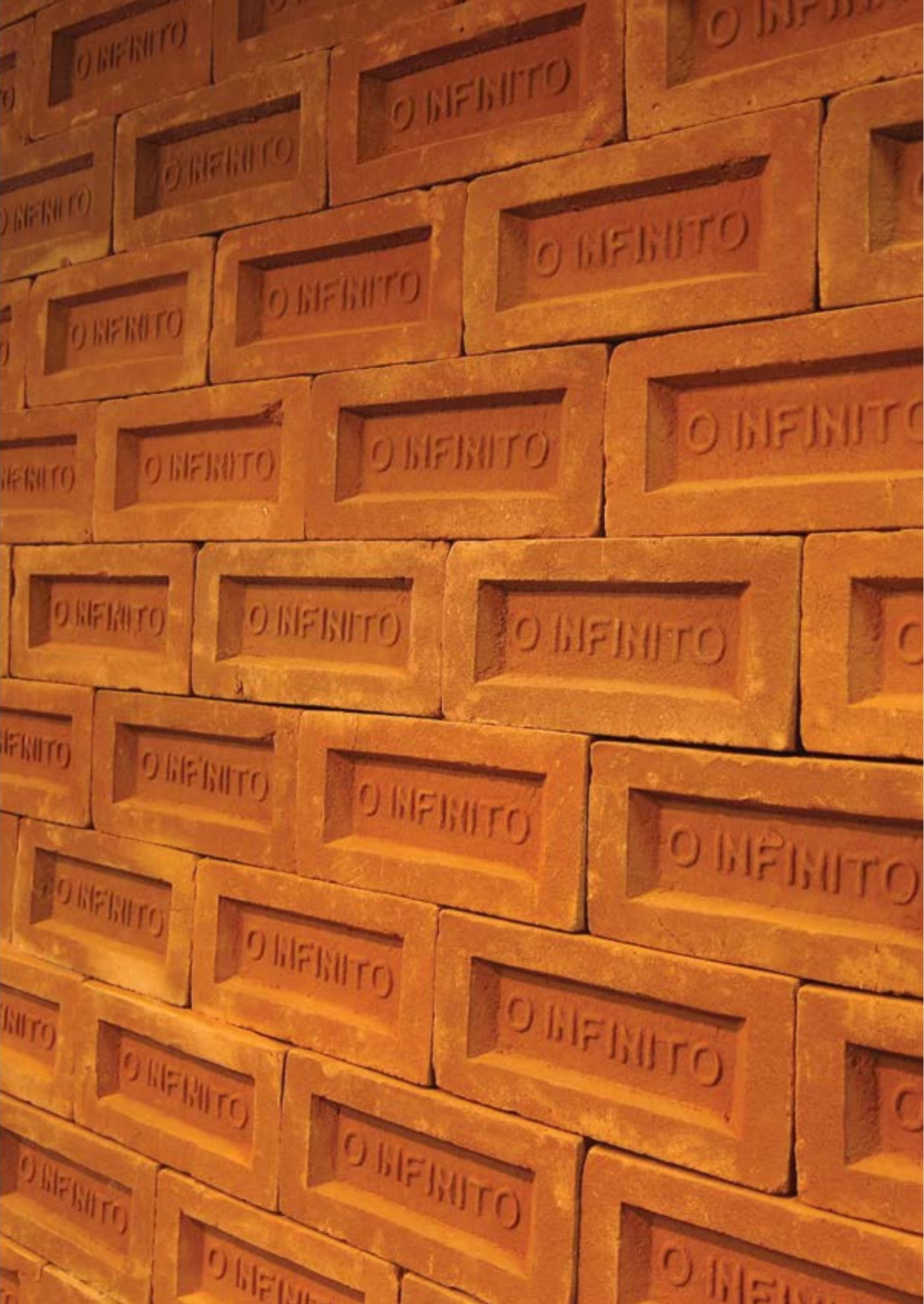




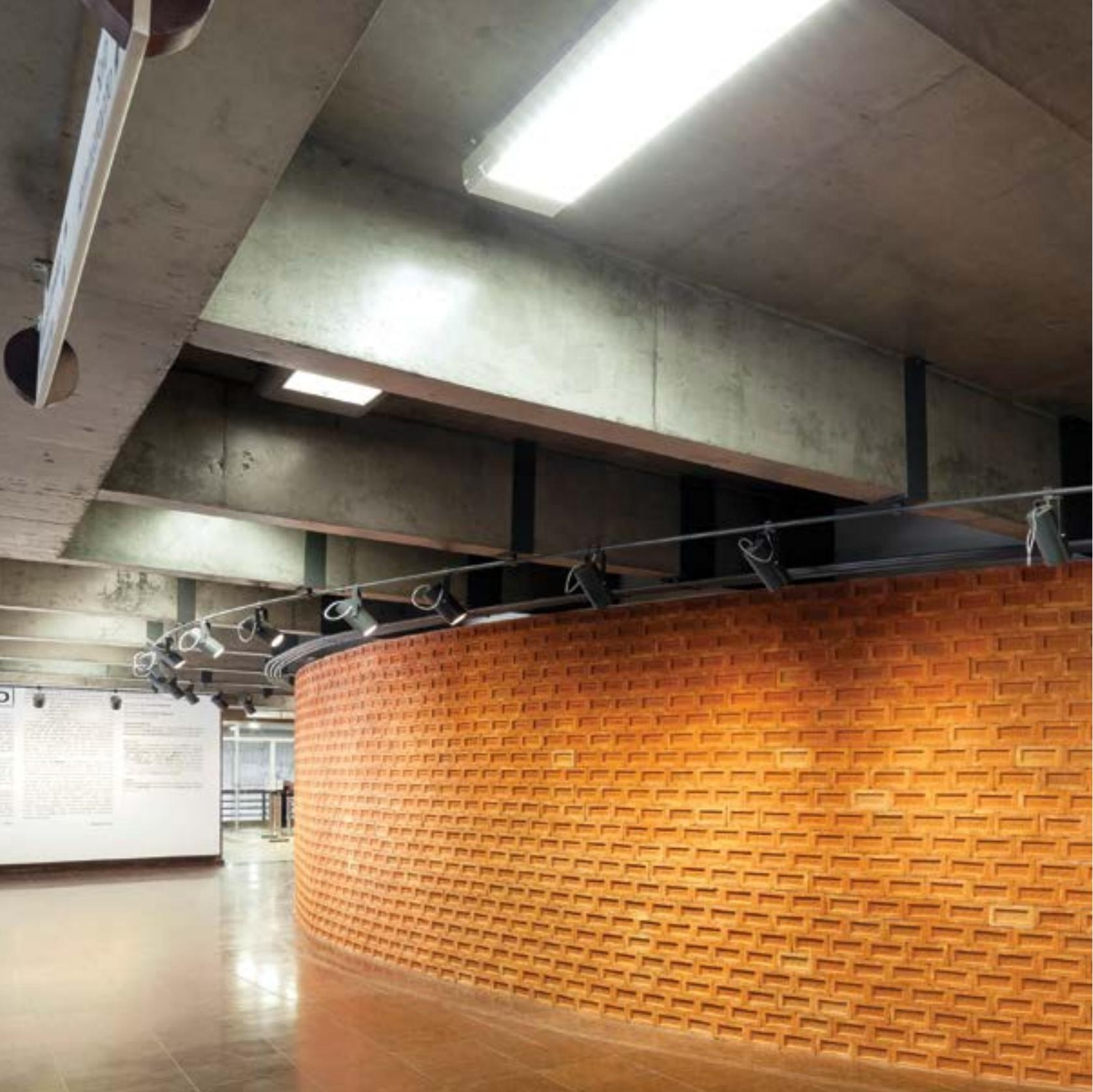





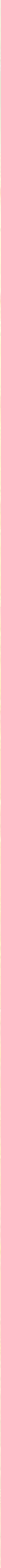




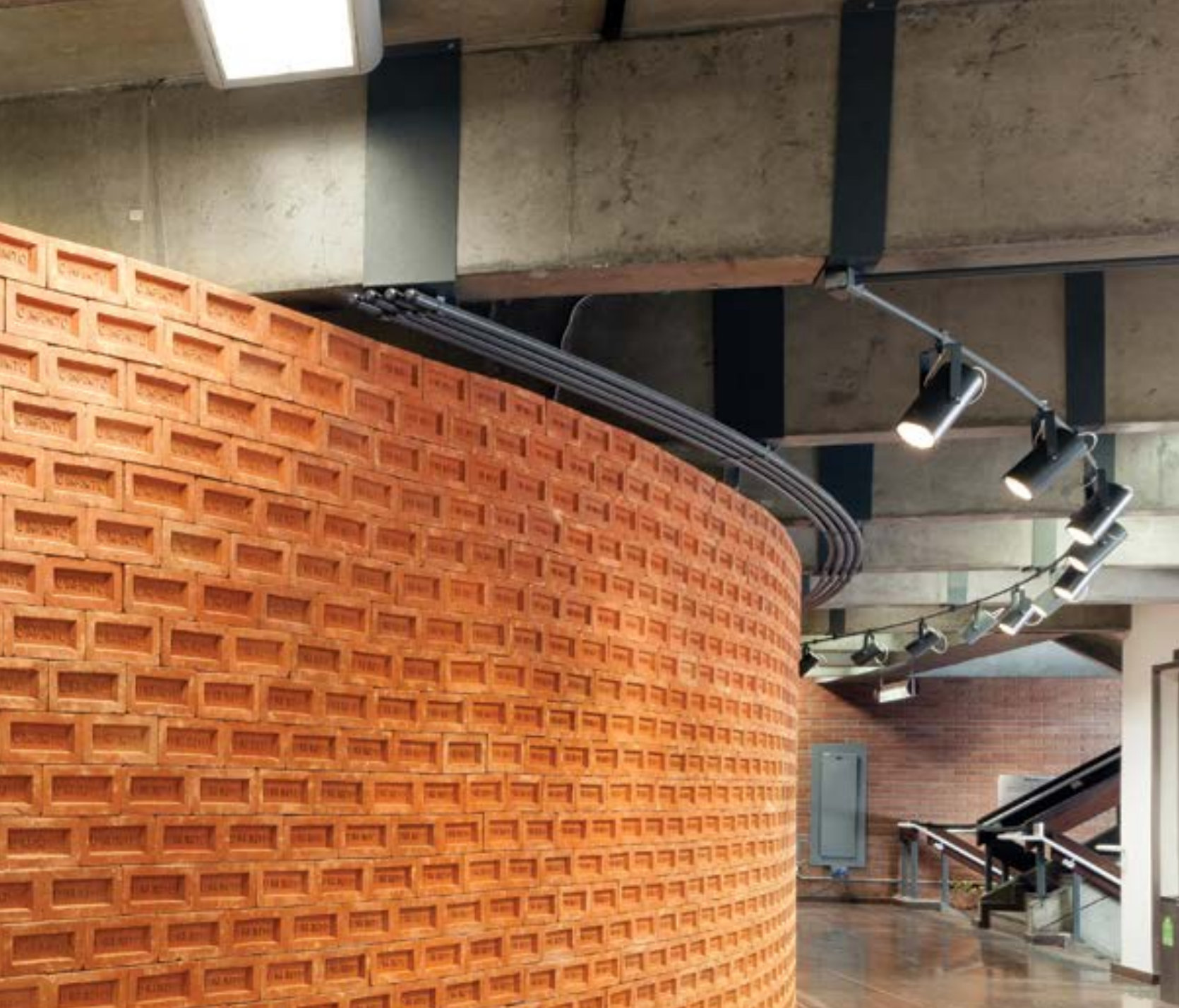

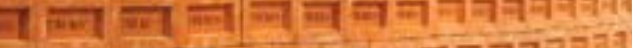
[101

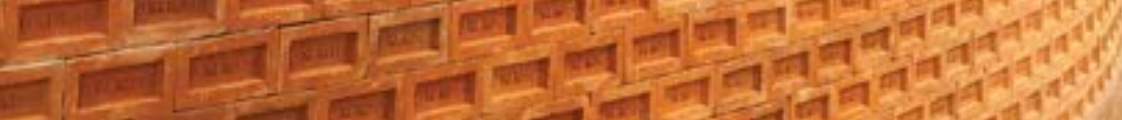




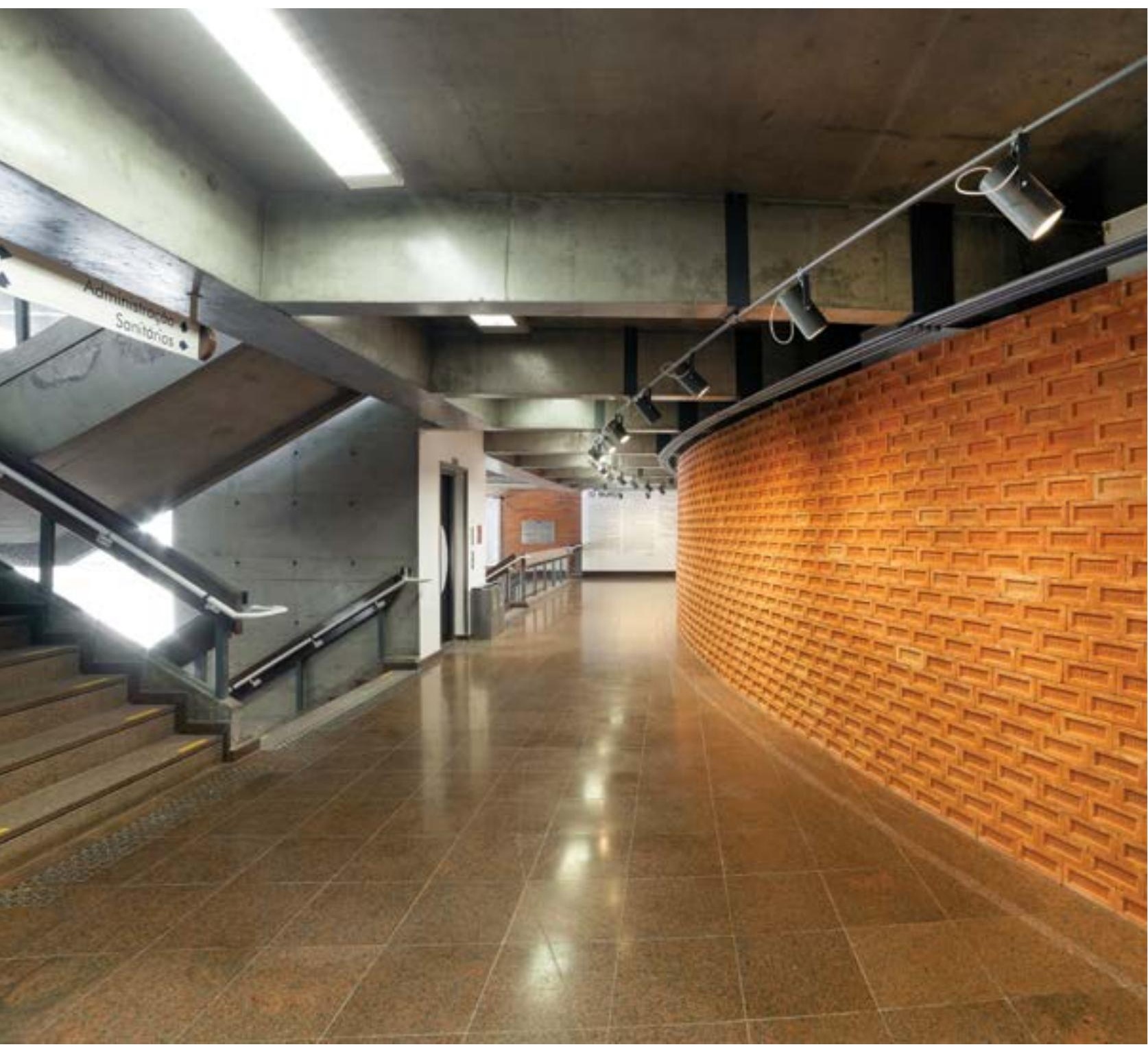



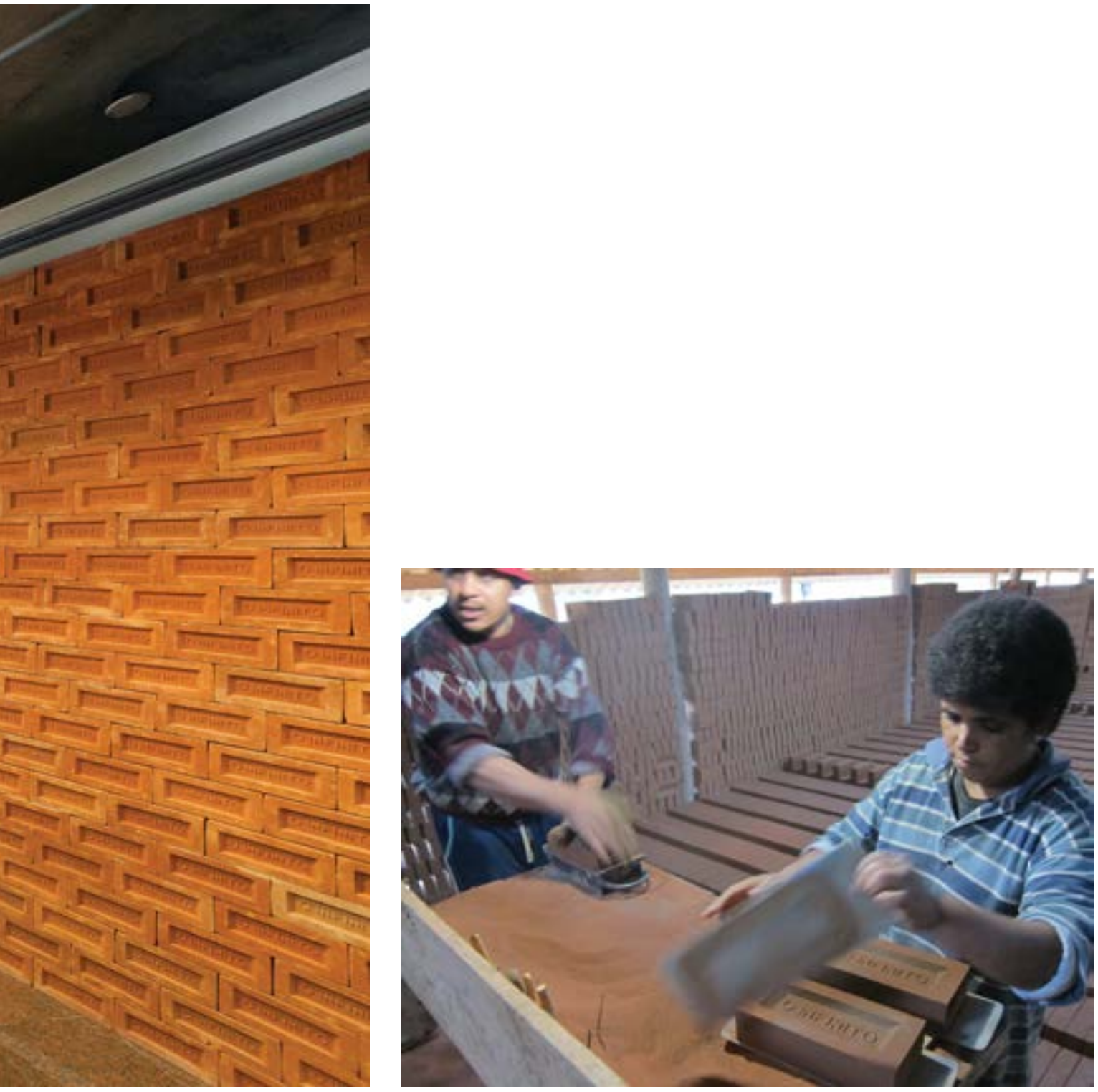


\section{6}

1.)

1
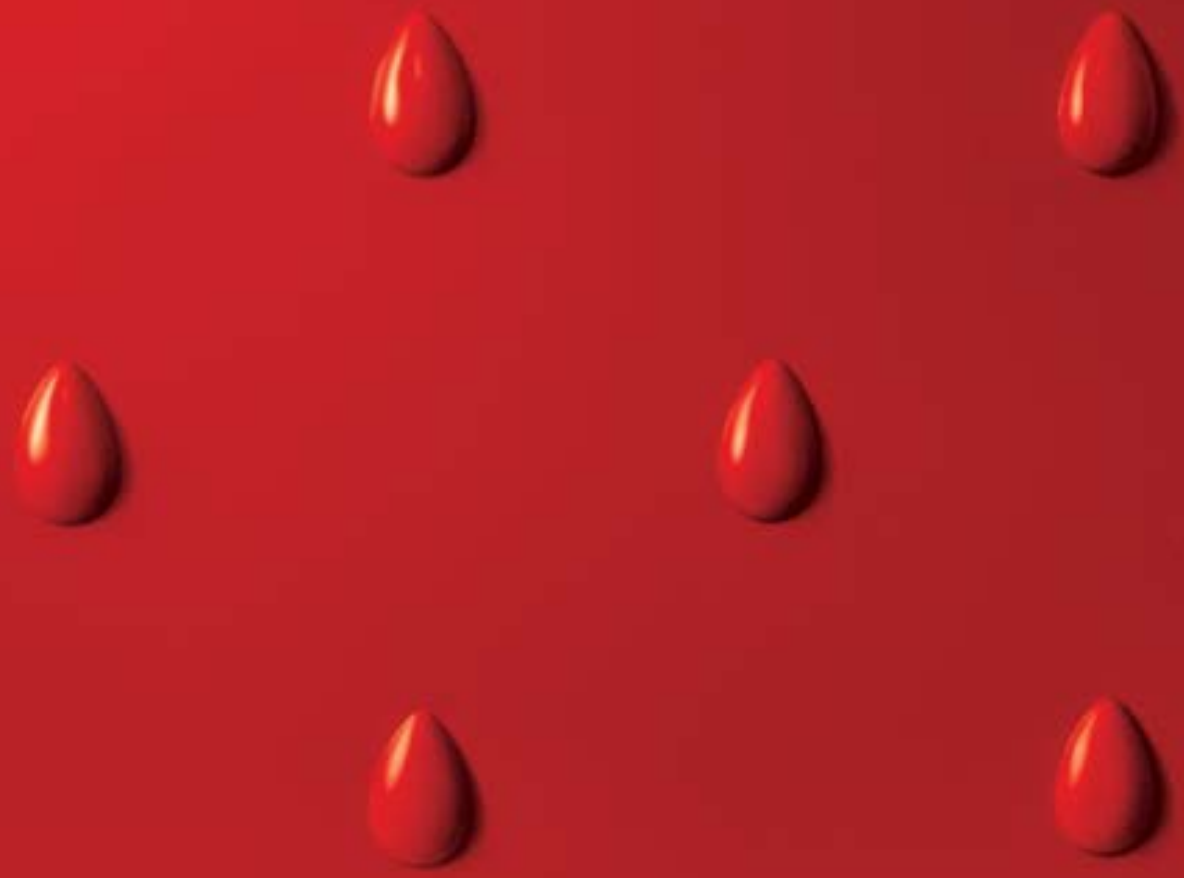


\section{SANGUE 2016}

Poliestireno termo-formado

Cada módulo: 40 × 60 cm, área total: $86 \mathrm{~m}^{2}$ (aproximadamente)

Sesc Santana, São Paulo - Exposição Individual

Sangue consiste no revestimento de um interior arquitetônico com módulos de plástico vermelho, alguns lisos e espelhados, e outros termo-formados que apresentam o relevo de pequenas gotas.

Duas provocações motivaram o seu desenvolvimento:

A primeira é uma resposta ao espaço arquitetônico do foyer do teatro do Sesc Santana, para onde foi originalmente desenhado. Pretende-se relacionar a intervenção com o desenho de outros interiores de teatros, cinemas e também hotéis, muitos deles de inspiração déco, como o nosso saudoso Gemini (na Avenida Paulista), hoje desativado, ou o Marabá (na Avenida Ipiranga), restaurado e funcionando, e ainda os sinistros corredores e ambientes do hotel Overlook, do filme O lluminado, de Santley Kubrick (1980), onde uma enxurrada de sangue invade o local. Ao repertório da decoração de interiores, soma-se o imaginário do "azulejamento" de paredes de interiores e fachadas vistos em arquiteturas populares, anônimas, pela cidade.

A segunda provocação é de ordem biográfica (motivada por um acidente de carro), mas pode levar a uma reflexão conceitual sobre a relação entre sujeito-cidade-arquitetura, muitas vezes entendidos e debatidos como conceitos abstratos que excluem a experiência íntima, emocional e orgânica desse sujeito. Busca-se, com Sangue, insistir na noção de corpo que transpira, chora, saliva, defeca, ejacula, sangra. Escorre, em síntese. 
$\therefore$ 

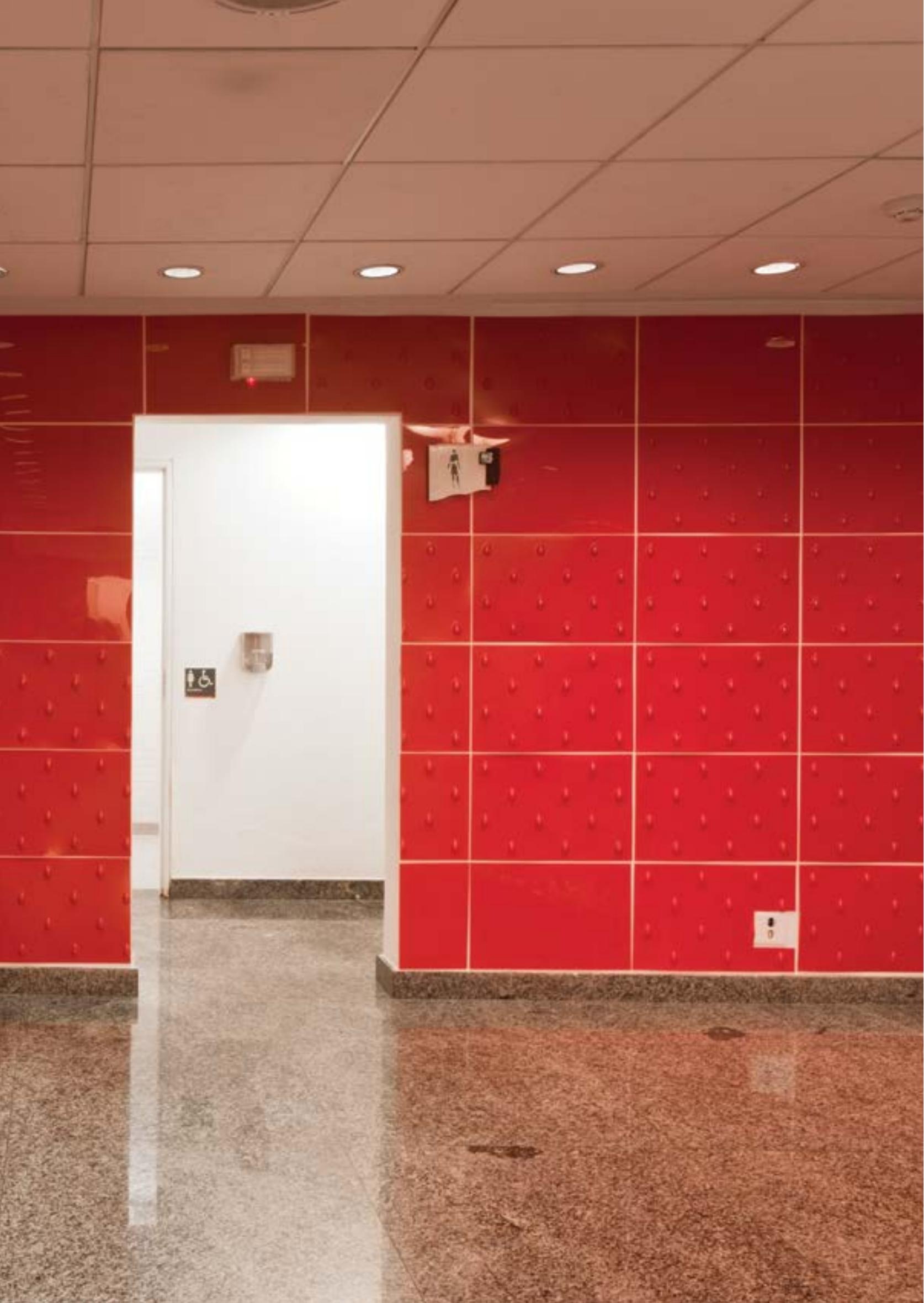



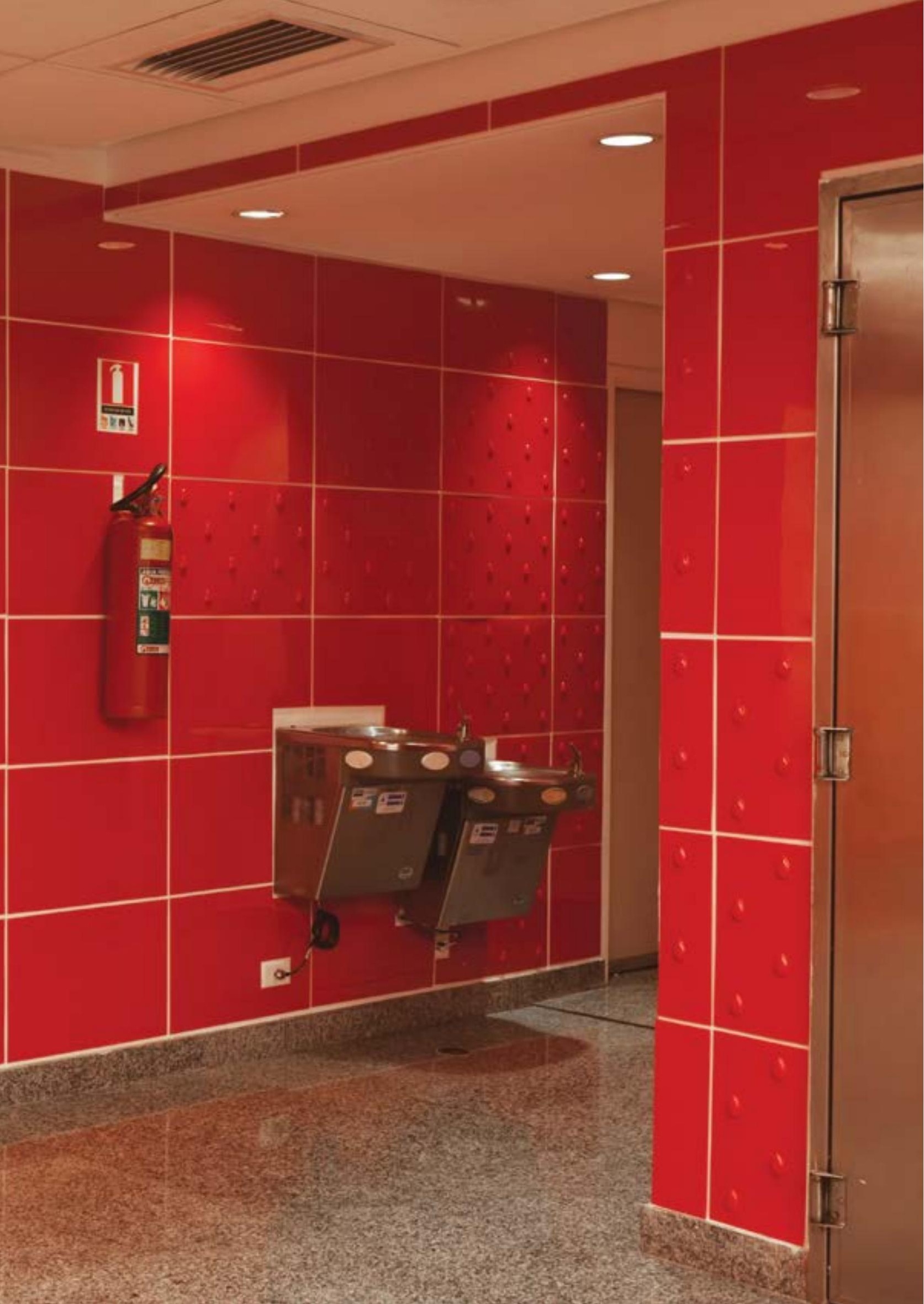





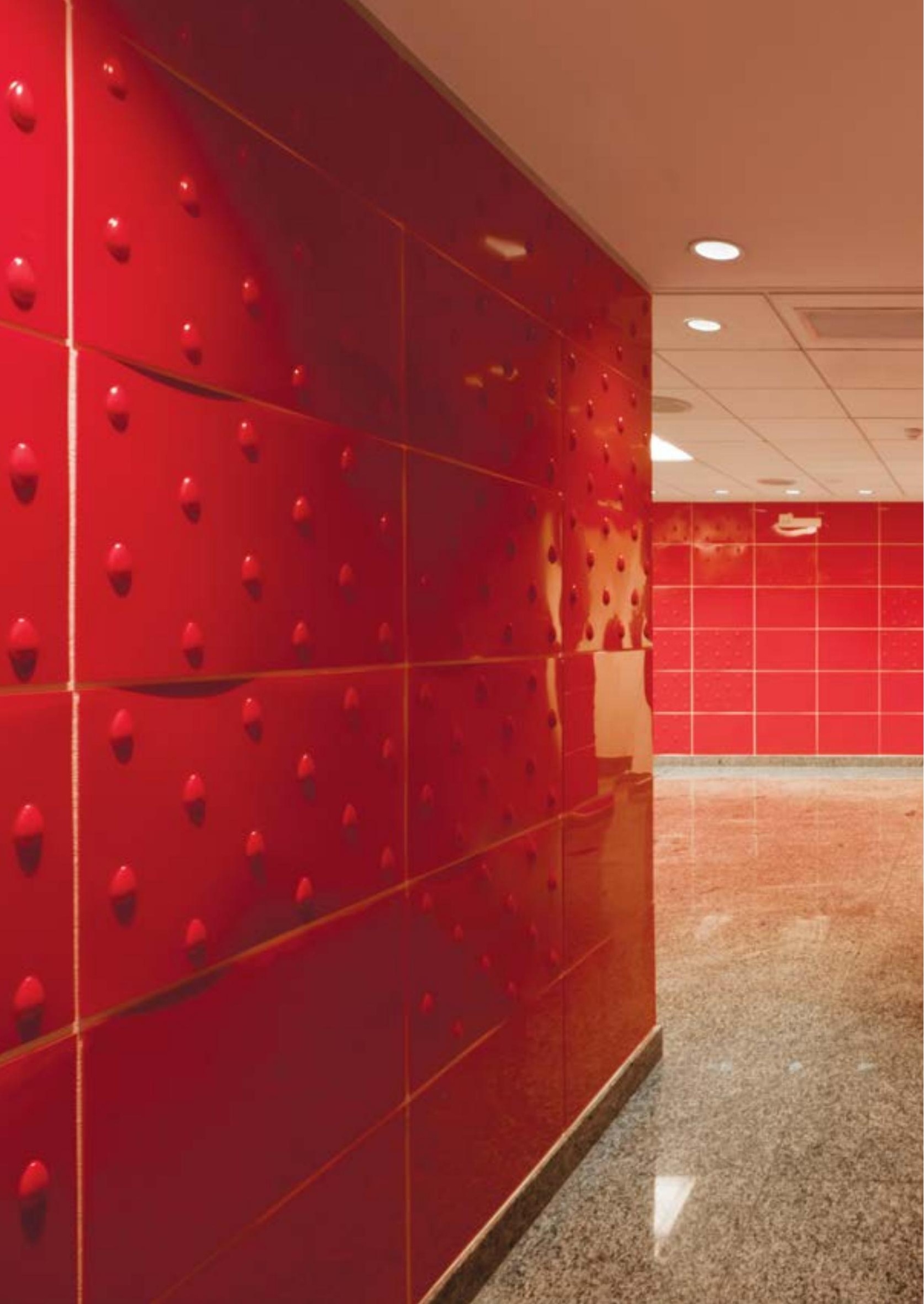


A instalação foi originalmente acompanhada por um vídeo, cujo objetivo era documentar e descrever as etapas de produção da obra. O vídeo acabou por exceder a intenção inicial, e sua presença simultânea à instalação parece ter adicionado outros conteúdos narrativos à obra. Sobrepuseram-se imagens da cidade de São Paulo, movimentos de câmera sensuais e lentos capturados no espaço da instalação vazio - impondo retração na temporalidade - e narração, por José Mojica Marins (Zé do Caixão), à maneira exagerada de uma notícia policial dotada de suspense e drama, de uma receita de galinha ao molho pardo, que inclui trechos como "pendure a galinha pelo pescoço por 15 minutos", "faca afiada" e "deixe escorrer todo o sangue". 

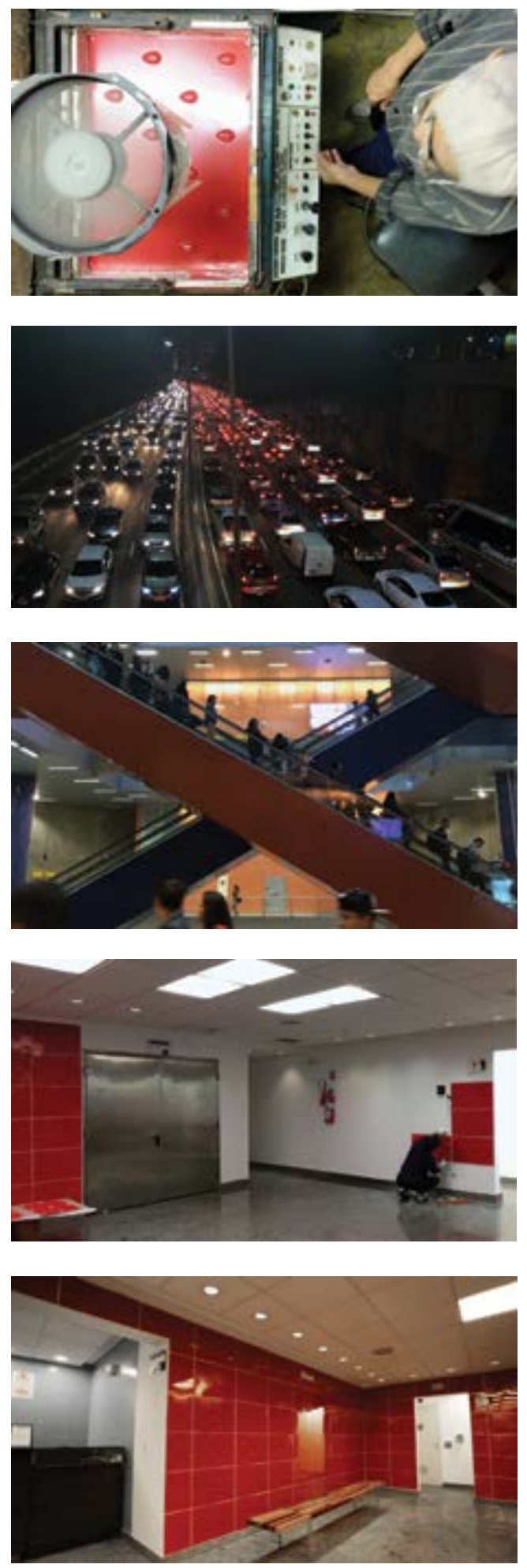

Sangue, 6'55", Vídeo de Renato Pera e Acácia Montagnolli, Narração: José Mojica Marins (Zé do Caixão), Fotografia: Acácia Montagnolli e Guilherme Y. Barbosa (Caraca Imagens), Edição: Acácia Montagnolli, Apoio: MonsterCam, Realização: Renato Pera e OitO produções artísticas, Colaboração: Amarílis Montagnolli, Embaform (Hiroshi), João Delle Piagge, Jefferson Siqueira. 


\section{VAZÃO 2015}

Objetos de fibra de vidro, pintura automotiva

$100 \times 60 \times 37 \mathrm{~cm}$ (cada objeto)

Parede Gentil, Galeria A Gentil Carioca, Rio de Janeiro, RJ - Exposição individual

"Ao que você dá vazão? À arquitetura. O que escorre, vaza na pele de uma arquitetura, é aquela ao redor que fica contida nas gotas. As gotas de "suor" não derretem, ao contrário, são receptáculos da paisagem, cada uma contém, cristaliza e reflete um aspecto do entorno da arquitetura ao redor. E mesmo antes do transeunte se aproximar e poder ver as imagens que as gotas refletem, ou simplesmente passar por elas, existe um acontecimento na fachada da galeria, como um suor, algo que está escorrendo e por quê?"

Daniela Maura Ribeiro, crítica de arte e curadora (em conversa com Renato Pera)

A obra pode parecer, à primeira vista, estranha aos demais trabalhos artísticos apresentados anteriormente. Desvia-se deliberadamente dos elementos arquitetônicos específicos (janelas, portas, tijolos e muros) e das escalas anteriores (ocorre aqui uma ampliação da escala), para que se busque uma conexão com temas relativos ao desenvolvimento urbano da cidade de São Paulo. O tema que "detona" a investigação para esta obra são relatos e memórias sobre as chuvas, cheias, inundações e sobre alguns rios, como o Tietê e o Pinheiros. 
Interessou entender as relações entre os meios naturais hídricos e a apropriação feita pelos processos de desenvolvimento urbano, muitas vezes capturados por interesses privados, assim como a relação direta e afetiva do habitante com esses mesmos recursos. Odette Seabra 32 , em sua tese sobre a canalização dos rios Tietê e Pinheiros, analisa de que modo interesses privados, notadamente aqueles que se referem à capitalização e propriedade do solo das antigas áreas de várzea, e à geração de energia elétrica, se sobrepuseram aos projetos urbanísticos e se anteciparam aos modos como o setor público pensava o uso dessas áreas.

Contudo, este é somente o "pano de fundo" da pesquisa.

Buscou-se ainda que o título ("Vazão") e a resolução formal (gotas pretas brilhantes espelhadas, com tamanho específico, sobrepostas a uma arquitetura) provocassem uma ampliação do campo de significados e códigos iniciais que motivaram as ideias para este trabalho. "Vazão" pareceu um termo que poderia ser dotado de muitos sentidos, inclusive aqueles que dizem respeito ao rio, às várzeas, e consequentemente, às cheias e às chuvas. Mas também poder-se-iam abrir para sentidos fisiológicos (suor, excreção, etc) e psicológicos.

A importância do reflexo, como foi sutilmente percebida pela crítica de arte Daniela Maura Ribeiro, consiste em conferir um funcionamento dinâmico, quase metabólico, entre intervenção, arquitetura e entorno.

\footnotetext{
32 Odette Carvalho de Lima Seabra, Os meandros dos rios nos meandros do poder - Tietê e Pinheiros: valorização dos rios e das várzeas na cidade de São Paulo. São Paulo: Dissertação de Doutorado, FFLCH - USP, 1987.
} 


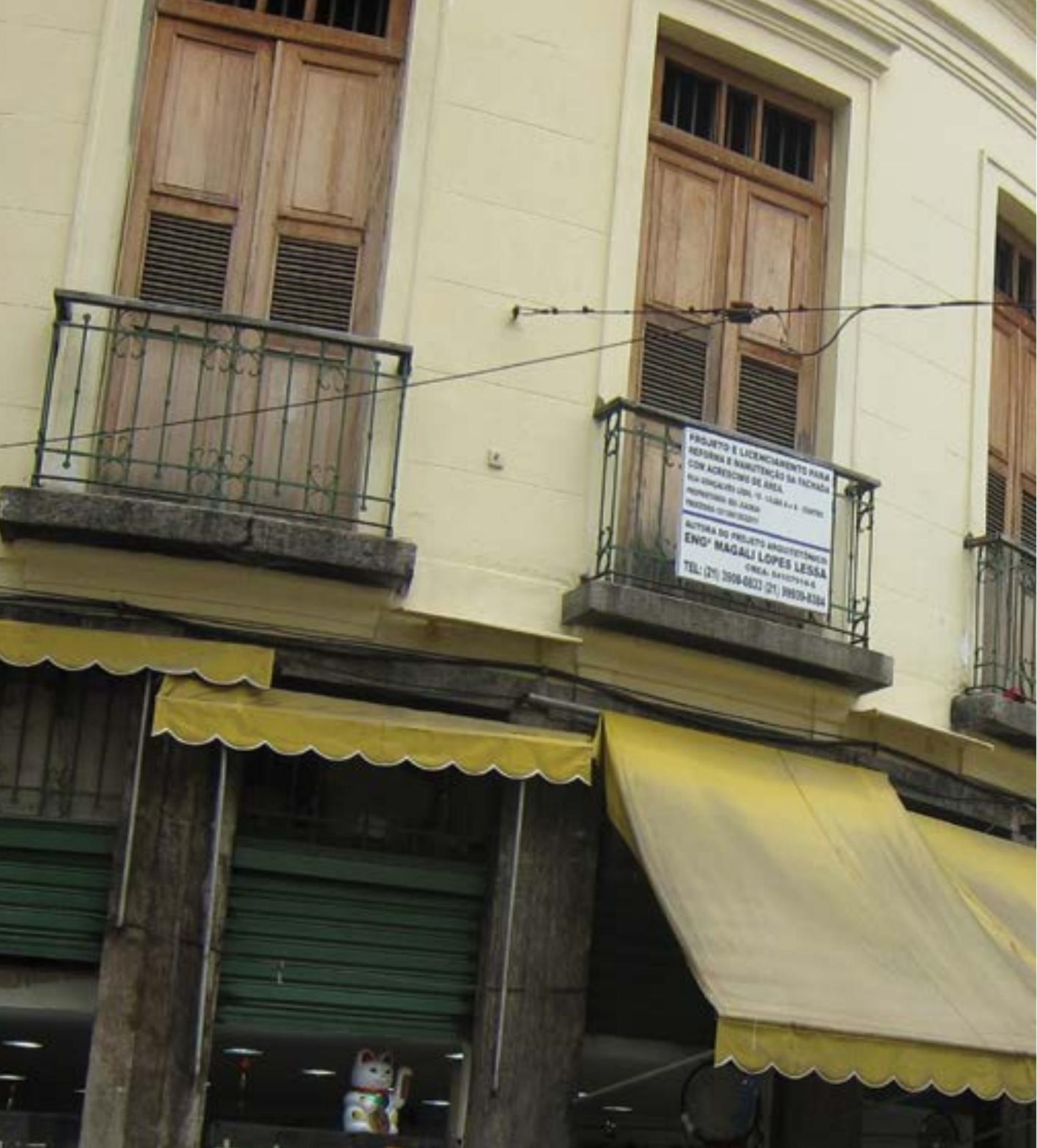

Caring

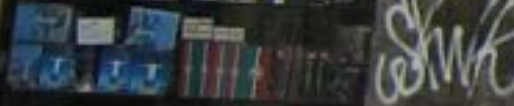
ii 


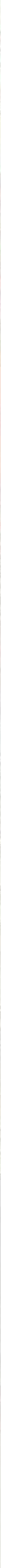


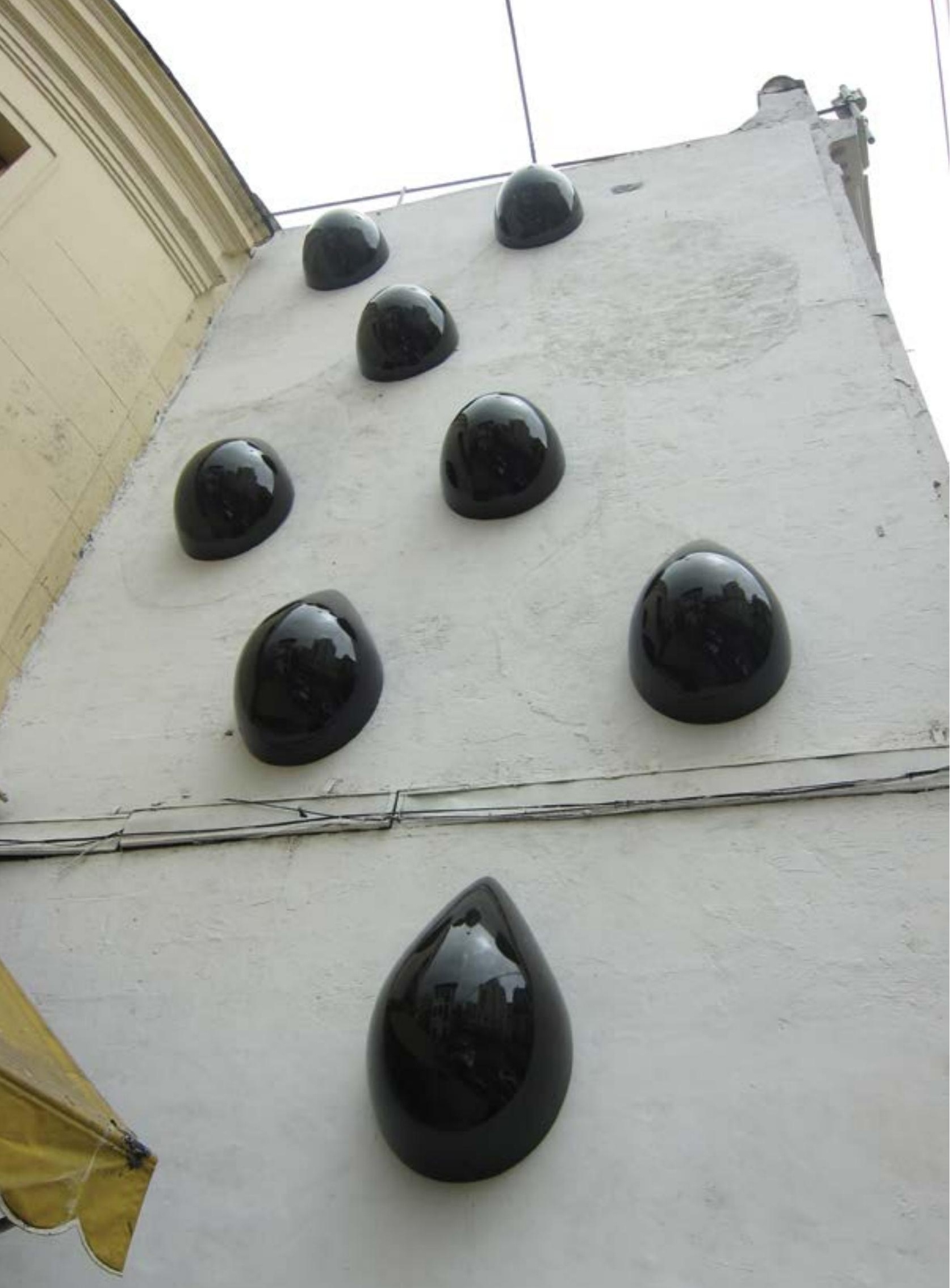




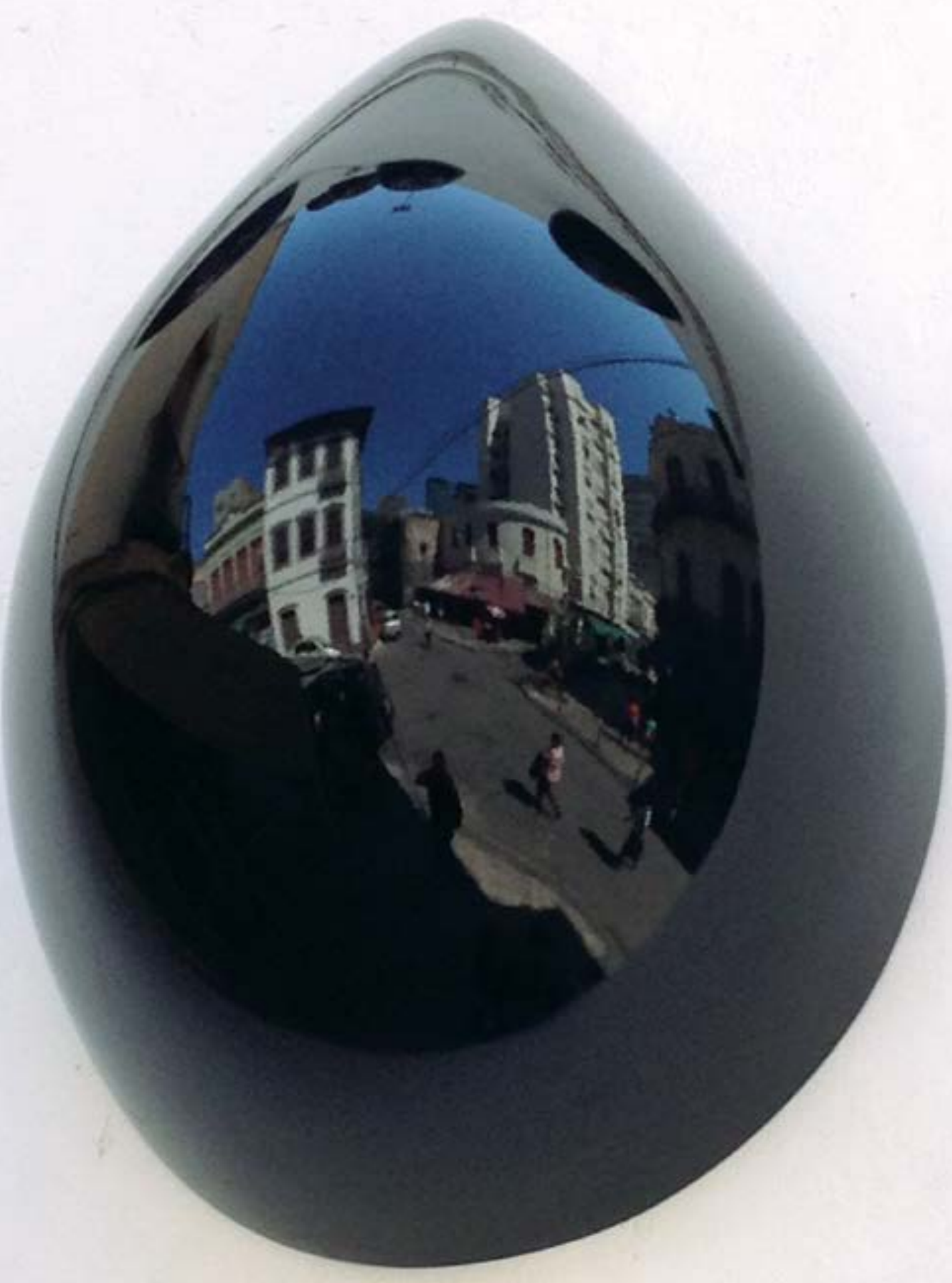




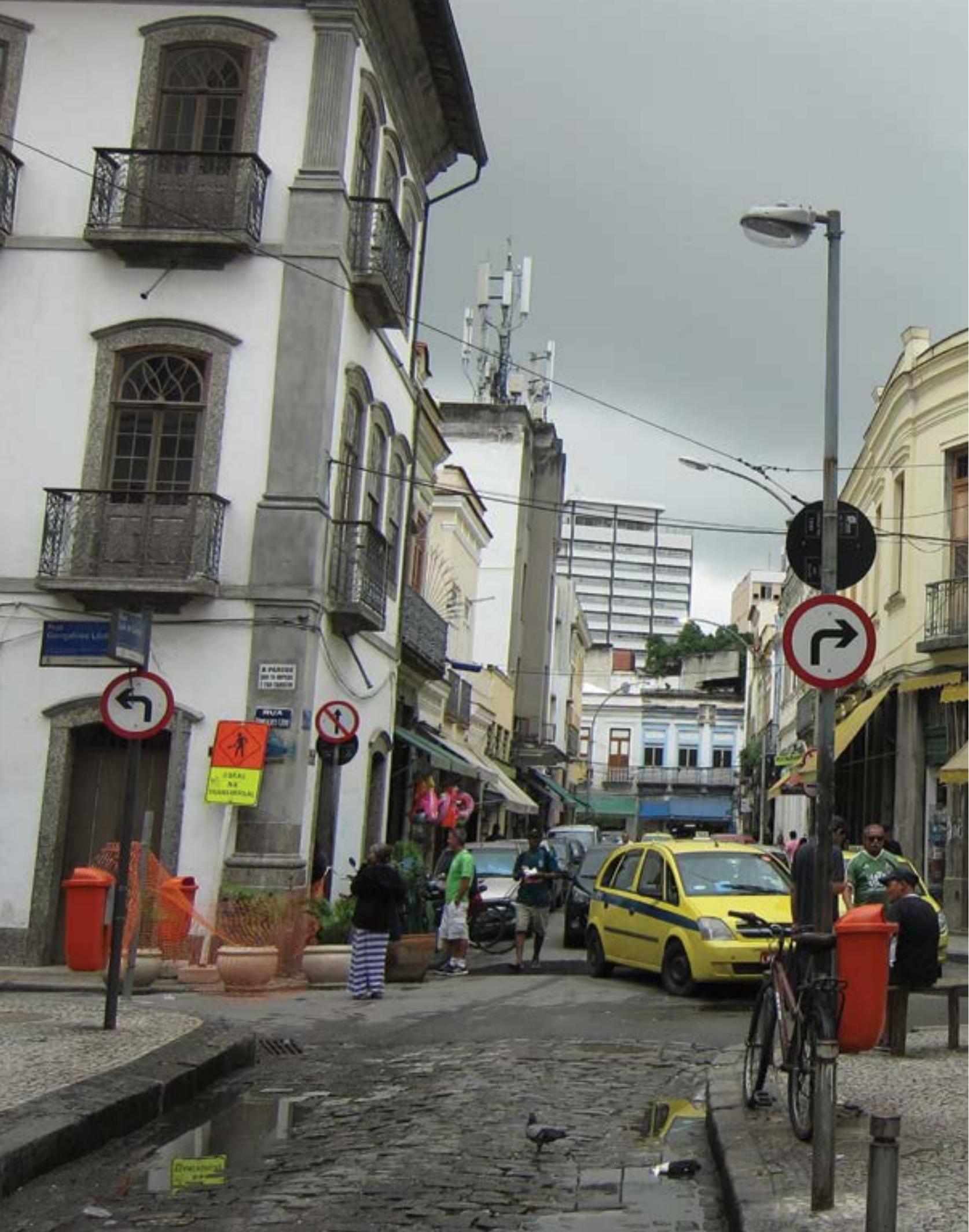




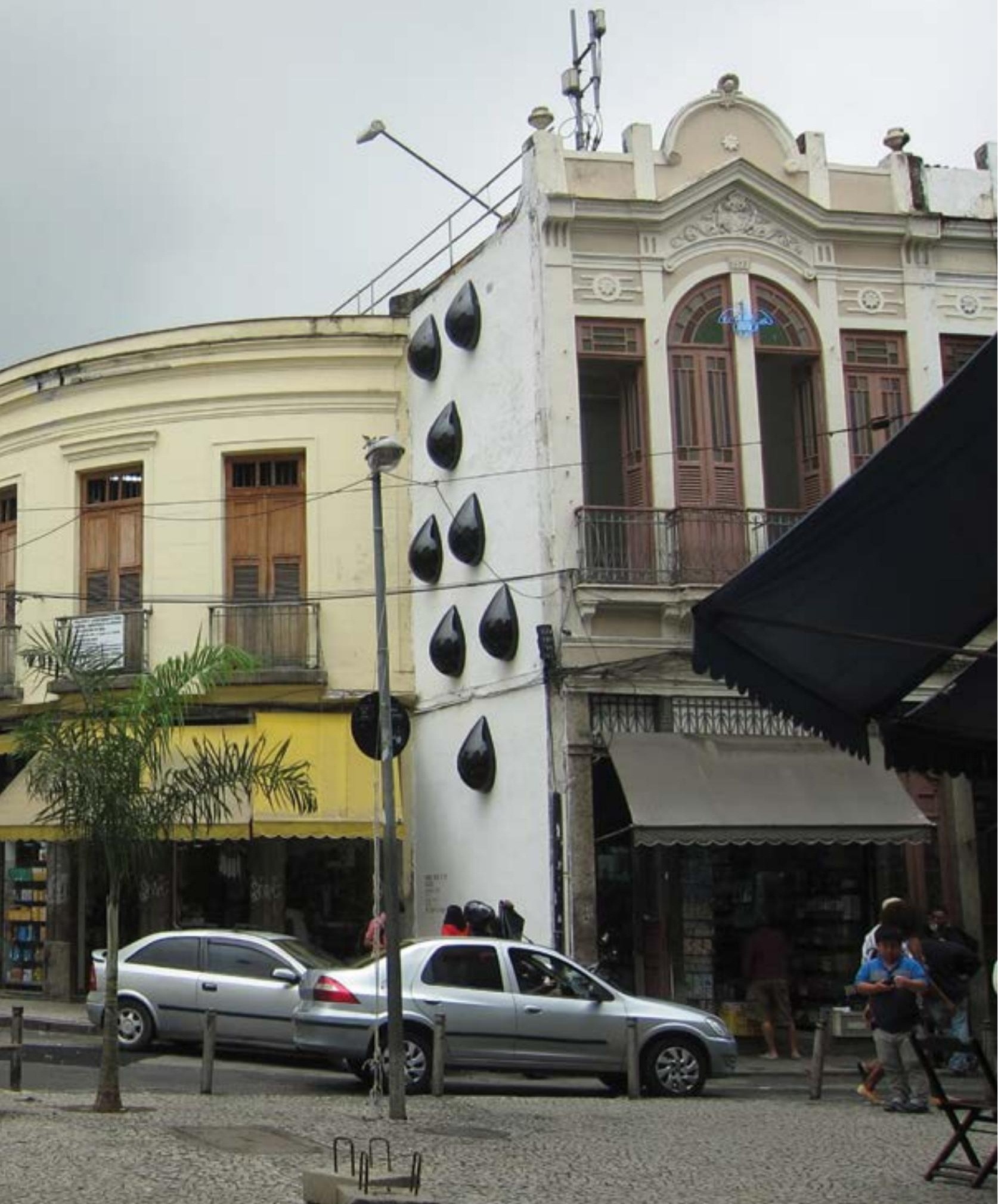





\section{BIBLIOGRAFIA}

Arquitetura e Urbanismo

AMARAL, Aracy A. (coord.). Arquitectura Neocolonial: América Latina, Caribe, Estados Unidos. São Paulo: Memorial Fondo de Cultura Económica, 1994.

CAMPOS, Candido Malta. Os rumos da cidade: urbanismo e modernização em São Paulo. São Paulo: Editora Senac, 2002.

CAMPOS, Eudes. Casas e vilas operárias paulistanas. Informativo do Arquivo Histórico Municipal. São Paulo: jul/ago, 2008, ano 4, n.19 [on line].

COELHO, Fernando (org.). O Rio Pinheiros. São Paulo: Secretaria de Estado do Meio Ambiente, 2002. COSTA, Lúcio. Arquitetura. Rio de Janeiro: Editora José Olympio, 2011 (6 Ed.).

COSTA, Lúcio. Documentação necessária, in Textos escolhidos da Revista do Instituto do Patrimônio Histórico e Artístico Nacional, São Paulo: Ministério da Cultura / IPHAN / FAU-USP, 1975.

COUTINHO, Aluízio Bezerra. O Problema da Habitação Higiência nos Países Quentes em Face da Arquitetura Viva. Rio de Janeiro: Officinas Alba Graphicas, 1930. In: Risco 2, Revista de Pesquisa em Arquitetura e Urbanismo do Programa de Pós-Graduação do Departamento de Arquitetura e Urbanismo EESC-USP. ISSN 1679-3498, 2005.

FERRAZ, Geraldo. Warchavchik e a introdução da nova arquitetura no Brasil: 1925 a 1940. Museu de Arte de São Paulo, 1965.

IDOETA, Ivan V.; IDOETA, Irineu; CINTRA, JorgeJorge Cintra. São Paulo Vista do Alto: 75 Anos de Aerofotogrametria. São Paulo: Editora Érica, 2004.

JORGE, Luís Antonio. A sintaxe da janela. Dissertação de Mestrado, FAU/USP, São Paulo, 1993.

O desenho da janela. São Paulo: Anablume, 1995.

LE CORBUSIER. Por uma arquitetura. São Paulo: Perspectiva / EDUSP, 1973.

LEMOS, Carlos A. C.. Alvenaria Burguesa: Breve História da Arquitetura Residencial de Tijolos em São Paulo a partir do Ciclo Econômico Liderado pelo Café, São Paulo: Nobel, 1985.

MARIANO FILHO, José; PINTO, Estevão. Influências Muçulmanas na Arquitetura Tradicional Brasileira, ed. A Noite, RJ, 1943.

MARINS, Paulo César Garcez. Através da Rótula: Sociedade e Arquitetura no Brasil, séculos XVII a XX. São Paulo: Humanitas/ FFLCH/ USP, 2001

MARINS, Paulo César Garcez. Habitação e Vizinhança: limites da privacidade no surgimento das metrópoles brasileiras, In: SEVCENKO, Nicolau (org.). História da Vida Privada no Brasil: República - Da Belle Époque à Era do Rádio. São Paulo: Companhia das Letras, 2006, v.3.

MATOS, Odilon Nogueira de. Café e Ferrovias: A Evolução Ferroviária de São Paulo e o Desenvolvimento da Cultura Cafeeira. São Paulo: Editora Alfa-Omega, 1974. 
MELLO, Joana. Ricardo Severo: da arqueologia portuguesa à arquitetura brasileira. São Paulo: Annablume / FAPESP, 2007.

PASSOS, Maria Lúcia Perrone; EMIDIO, Teresa. Desenhando São Paulo: mapas e literatura: 1877 - 1954. Editora Senac São Paulo: Imprensa Oficial, 2009.

PINTO, Estevão. Muxarabis e Balcões, in Textos escolhidos da Revista do Instituto do Patrimônio Histórico e Artístico Nacional, São Paulo: Ministério da Cultura / IPHAN / FAU-USP, 1975, Pg. 47-88.

REIS FILHO, Nestor Goulart. Quadro da arquitetura no Brasil. São Paulo: Perspectiva, 2011.

REIS FILHO, Nestor Goulart. São Paulo: Vila, Cidade, Metrópole. Prefeitura de São Paulo, 2004.

REIS FILHO. Nestor Goulart. Racionalismo e Proto-Modernismo na Obra de Victor Dubugras. São Paulo: Fundação Bienal De São Paulo, 1997.

RODRIGUES, José Wasth. A casa de moradia no Brasil antigo, In: Textos escolhidos da Revista do Instituto do Patrimônio Histórico e Artístico Nacional, São Paulo: Ministério da Cultura / IPHAN / FAU-USP, 1975, Pg. 283-318.

RODRIGUES, José Wasth. Documentário Arquitetônico Relativo à Antiga Construção Civil no Brasil. São Paulo: Ed. USP / Martins Fontes, 1975.

ROLNIK, Raquel. São Paulo, São Paulo: Publifolha, 2003.

SEABRA, Odette Carvalho de Lima. Os meandros dos rios nos meandros do poder - Tietê e Pinheiros: valorização dos rios e das várzeas na cidade de São Paulo. São Paulo: Dissertação de Doutorado, FFLCH - USP, 1987.

SEGAWA, Hugo. Arquiteturas no Brasil 1900 - 1990. São Paulo: EDUSP, 2002.

SEVCENKO, Nicolau. Orfeu Extático Na Metrópole: São Paulo, Sociedade E Cultura Nos Frementes Anos 20, São Paulo: Companhia Das Letras, 1992.

SILVA, Lucia Sousa e. A cidade e a floresta: o impacto da expansão urbana sobre áreas vegetadas na Região Metropolitana de São Paulo (RMSP). São Paulo, 2013. Tese (Doutorado), Programa de Pós-Graduação em Ciência Ambiental da Universidade de São Paulo / orietação: Prof. Dra. Marta Dora Grostein.

SOUZA, Maria Adélia Aparecida de. Metrópole e paisagem: caminhos e descaminhos da urbanização, In Paulo Porta (org.), História da Cidade de São Paulo, v.3: a cidade na primeira metade do século XX, São Paulo: Paz e Terra, 2004.

TOLEDO, Benedito Lima de. São Paulo: Três Cidades Em Um Século, São Paulo: Duas Cidades, 1983.

Arte

ARGAN, Giulio Carlo. Arte Moderna. São Paulo: Companhia das Letras, 1992.

AZEVEDO, Militão Augusto de; TOLEDO, Benedito Lima de; LEMOS, Carlos. Álbum Comparativo da Cidade de São Paulo 1862 - 1887, Militão Augusto de Azevedo, SÃO PAULO: Prefeitura do Município de São Paulo / Secretaria Municipal de Cultura, 1981. 
BACHELARD, Gaston. A poética do espaço. São Paulo: Martins Fontes, 2008.

BISHOP, Claire. Installation art: a critical history. New York: Routledge, 2005.

CRARY, Jonathan. Foreword In OLIVEIRA, Nicolas et all, Installation art in the new millennium, Londres: Thames \& Hudson, 2003.

DIDI-HUBERMAN, Georges. A imagem sobrevivente: história da arte e tempo dos fantasmas segundo Aby Warburg. Trad. Vera Ribeiro. Rio de Janeiro: Contraponto, 2013.

DIDI-HUBERMAN, Georges. Diante do Tempo: História da arte e anacronismo das imagens. Belo Horizonte: Editora UFMG, 2015.

DIDI-HUBERMAN, Georges. "Cascas" (2011), In Revista Serrote, São Paulo: Instituto Moreira Salles, Março 2013, n. 13.

DILLON, Brian. Ruins - Documents of Contemporary Art, Whitechapel (Londres) e MIT Press (Cambridge), 2011.

FOSTER, Hal. O complexo arte-arquitetura. São Paulo: Cosac Naify, 2015.

JUDD, Donald. Objetos específicos In FERREIRA, Glória; COTRIM, Cecilia (org.) Escritos de artistas: anos 60/70. Rio de Janeiro: Zahar, 2006.

JUNIOR, Rubens Fernandes et al. Militão Augusto de Azevedo. São Paulo: Cosac Naify, 2012.

KOOLHAAS, Rem et all. Window In Elements of architecture. Veneza: Marsilio, 2014 Venice Architecture Biennale.

KRAUSS, Rosalind. "A Voyage on the North Sea": Art in the Age of the Post-Medium Condition. Londres: Thames \& Hudson, 2000.

KRAUSS, Rosalind. Caminhos da escultura moderna, São Paulo: Martins Fontes, 2001.

KWON, Miown. One place after another: site-specific art and locational identity. Massachusetts: MIT Press, 2002.

LAGO, Pedro Corrêa do. Militão Augusto de Azevedo: São Paulo nos anos 1860. Rio de Janeiro: Editora Capivara, 2001.

MANO, Rubens. Intervalo Transitivo. Dissertação de Mestrado, São Paulo: Escola de Comunicações e Artes da Universidade de São Paulo, 2003.

MEDEIROS, Marjorie de CarvalhoF.de;BARBOSA, GinoCaldatto. SãoPaulo Railway:Álbum EstradadeFerro, Militão Augusto de Azevedo, São Paulo: Magma Editora Cultural, 2010.

TARKOVSKIAEI,AndreaeiArsensevick.Tarkovski/Esculpirotempo.Trad.JeffersonLuizCamargo.SãoPaulo, Martins Fontes, 1998 (2a edição). 
Créditos das imagens

Acácia Montagnolli: páginas 44, 46 - 50, 52 - 57, 59, 60, 75, 86 - 93.

Filipe Berndt: páginas $78-82$.

Genésio Filho: página 83.

Miguel Ángel Martinez: páginas 70 - 74.

Renato Pera: páginas 17, 30, 37, 46, 64, 66, 77, 84, 96 - 105.

Victor Dias: páginas 62, 63.

Imagens encontradas na internet: $25-27$.

Capa

Figura, 2016

Plástico termo-formado

Total de 6 modelos

Realização: Embaform 

